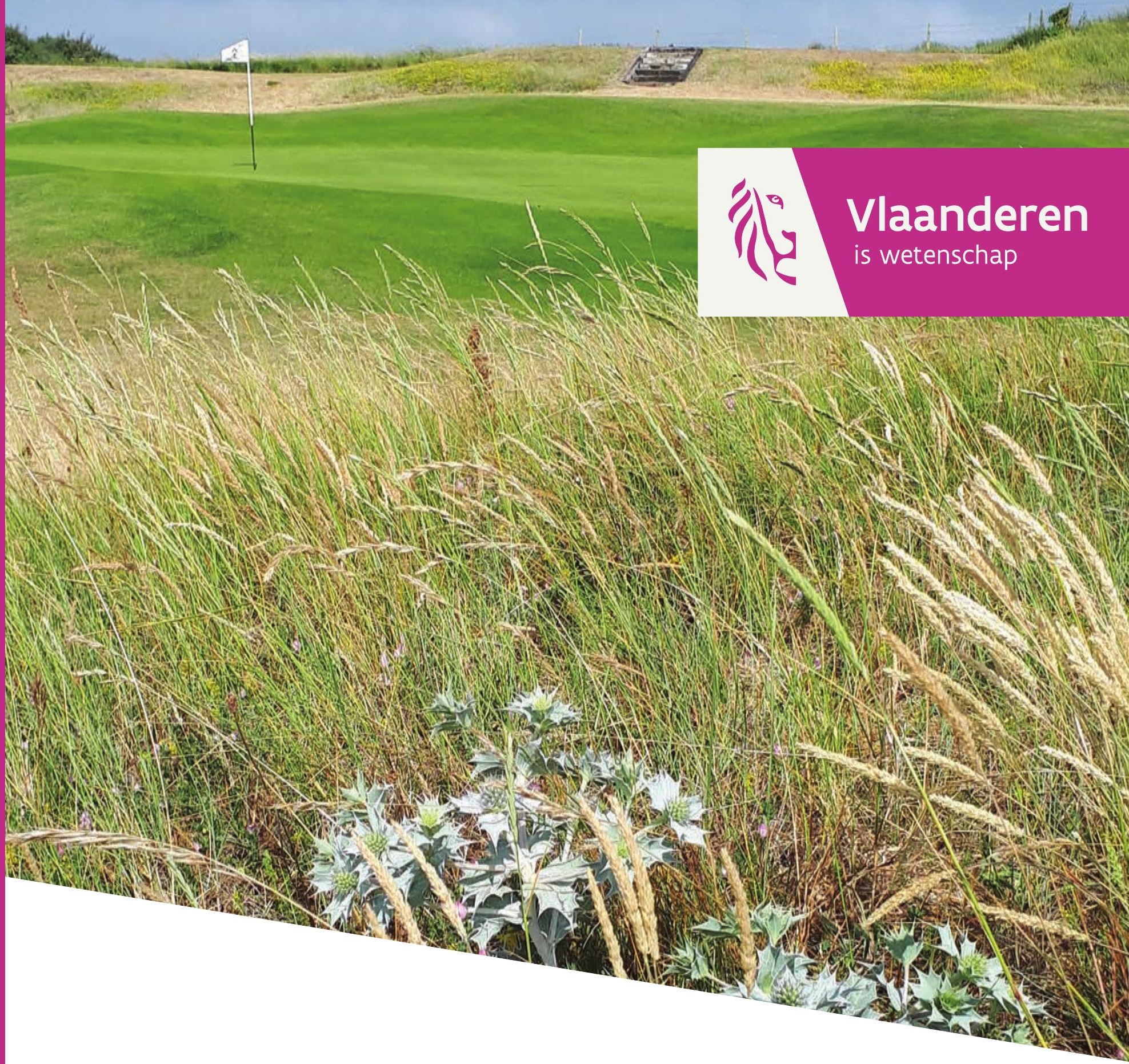

\title{
Inventarisatie van flora en vegetatie op de Golf van De Haan
}

Sam Provoost, Wouter Van Gompel \& Ward Vercruysse 


\section{Auteurs:}

Sam Provoost, Wouter Van Gompel \& Ward Vercruysse

Instituut voor Natuur- en Bosonderzoek

Het Instituut voor Natuur- en Bosonderzoek (INBO) is het Vlaams onderzoeks- en kenniscentrum voor natuur en het duurzame beheer en gebruik ervan. Het INBO verricht onderzoek en levert kennis aan al wie het beleid voorbereidt, uitvoert of erin geïnteresseerd is.

\section{Vestiging:}

INBO

Herman Teirlinckgebouw

Havenlaan 88 bus 73

1000 Brussel

www.inbo.be

e-mail:

Sam.Provoost@inbo.be

\section{Wijze van citeren:}

Provoost S, Van Gompel W \& Vercruysse W (2018). Inventarisatie van flora en vegetatie op de Golf van De Haan.

Rapporten van het Instituut voor Natuur- en Bosonderzoek 2018 (101). Instituut voor Natuur- en Bosonderzoek, Brussel. DOI: doi.org/10.21436/inbor.15763861

\section{D/2018/3241/358}

Rapporten van het Instituut voor Natuur- en Bosonderzoek 2018 (101)

ISSN: 1782-9054

Verantwoordelijke uitgever:

Maurice Hoffmann

\section{Foto cover:}

Sam Provoost

Dit onderzoek werd uitgevoerd in opdracht van:

Koninklijke Golf Club Oostende

Koninklijke Baan 2 - 8420 De Haan 


\section{Inventarisatie van flora en vegetatie op de Golf van De Haan}

Sam Provoost, Wouter Van Gompel \& Ward Vercruysse

Met medewerking van het team Landschapsecologie en Natuurbeheer van het INBO

Rapporten van het Instituut voor Natuur- en Bosonderzoek 2018 (101)

D/2018/3241/358 


\section{Inhoud}

Inhoud

1. Inleiding

2. Methodiek

2.1. Detailkartering van aandachtssoorten

2.2. Permanente kwadraten

2.3. Vegetatiekartering

3. Resultaten

3.1. Detailkartering van aandachtssoorten

3.1.1. Algemeen

6

3.2.2. Bespreking per soort

3.3. Vegetatiekaart

66

3.3. Uitheemse planten

3.4. Permanente kwadraten

4. Ecologische waarde, knelpunten en potenties

4.1. Visie op natuurontwikkeling

4.2. Omvorming van uitheemse struwelen en bossen

4.3. Ontwikkeling van vochtige duinvalleien

4.4. Ontwikkeling van duingrasland

4.5. Beheer van duingrasland 80

4.6. Biotisch herstel 86

Referenties 


\section{Inleiding}

Aanleiding van deze studie is een herziening van het beheerplan voor het golfterrein van De Haan. De voorbije jaren heeft de uitbater, de Koninklijke Golfclub Oostende, aanzienlijke inspanningen geleverd om de natuurwaarden van het terrein te verhogen. Het maairegime werd aangepast, de beregening verminderd, exoten werden gekapt en op twee plaatsen werden duinvalleien hersteld. Deze studie omvat een gedetailleerde inventarisatie van een selectie van bijzondere plantensoorten en een kartering van de vegetatie aan de hand waarvan we deze maatregelen willen evalueren. Vooral de kartering van aandachtssoorten leent zich hiertoe gezien er in het verleden al gelijkaardige inventarisaties zijn gebeurd en hierdoor trends kunnen worden bepaald.

\section{Methodiek}

\subsection{Detailkartering van aandachtssoorten}

Volgens de methodiek uitgewerkt in het project 'PINK' (Permanente Inventarisatie van de Natuurreservaten aan de Kust, Provoost et al. 2010), werd op de golf een selectie van aandachtssoorten (vaatplanten) gedetailleerd en gebiedsdekkend in kaart gebracht. De selectie van deze soorten is vooral gebaseerd op zeldzaamheid en trend in Vlaanderen (Rode lijst) maar wordt aangevuld met een aantal ecologisch specifieke, aan de kust zeldzame soorten die in het binnenland lokaal algemener kunnen zijn. Het betreft onder meer soorten die relatief veel voorkomen in de zure zandstreken en die in de duinen specifiek aan oudere ontkalkte duinlandschappen gebonden zijn. Op de golf betreft het bijvoorbeeld eenjarige hardbloem, zilverhaver, zwarte zegge en borstelbies. Daarenboven wordt een selectie van niet inheemse soorten gekarteerd als negatieve indicatoren. Daarbij ligt de nadruk op beheerbaarheid. Volledig ingeburgerde kruidachtige soorten als Canadese fijnstraal, bezemkruiskruid of teunisbloemen die onmogelijk nog kunnen bestreden worden, karteren we niet mee. De gekarteerde soorten zijn vooral struiken.

Op het terrein worden groeiplaatsen van soorten vooral als punt gekarteerd met behulp van GPS. We gebruikten hiervoor in de Garmin Foretrex, een compacte hand-gps met een gemiddelde fout van $2,5 \mathrm{~m}$ in open terrein en bij goede satellietontvangst. In bosrijke terreindelen moet rekening gehouden worden met fouten tot ca. $10 \mathrm{~m}$. De tracks van deze gps wordt eveneens bijgehouden in een geodatabank en geven een goed beeld van de geleverde inventarisatie-inspanning. Grotere groeiplaatsen van aandachtssoorten worden ook als vlakje aangeduid op een luchtfoto en vervolgens in ArcGIS gedigitaliseerd. Per waarneming, punt of vlak, worden soort, waarnemer, datum en abundantie genoteerd. Dit laatste wordt uitgedrukt in aantal exemplaren bij individueel groeiende soorten (bv. ruwe klaver, bokkenorchis of ratelaar-soorten) of als oppervlakte bij klonaal uitbreidende soorten zoals grote tijm, geel zonneroosje of cipreswolfsmelk (tabel 2.1).

Tabel 2.1. Abundantiecode gebruikt bij detailkartering.

\begin{tabular}{|c|c|c|c|}
\hline Code & Aantal exemplaren & Groeiplaats $\left(\mathbf{m}^{\mathbf{2}}\right)$ & Mediaan \\
\hline a & 1 & $<1$ & 1 \\
b & $2-5$ & $2-5$ & 3 \\
c & $6-25$ & $6-25$ & 12 \\
d & $26-50$ & $26-50$ & 35 \\
e & $51-500$ & $51-500$ & 200 \\
f & $501-5000$ & $501-5000$ & 2000 \\
g & $>5000$ & $>5000$ & 7500 \\
\hline
\end{tabular}


Alle gekarteerde punten en vlakken worden ingeladen in het GIS (ArcGIS 10). Verwerking gebeurt door verrastering van alle gegevens naar een GIS-rooster van $25 \times 25 \mathrm{~m}^{2}$. Hiermee kunnen de karteringen uit verschillende perioden gemakkelijk met elkaar vergeleken worden (aantal roostercellen) en worden dat geografische onnauwkeurigheden afgevlakt. De verrastering gebeurt via een GIS-overlay van alle punten en vlakken met een vector-roosterkaart. Alle waarnemingen per jaar die binnen een roostereenheid vallen worden samengenomen en de abundanties worden opgeteld op basis van de mediaan van de klassen (tabel 2.1). Bij vlakjes die over meerdere roostercellen vallen wordt de abundantie verdeeld, proportioneel met de oppervlakte die binnen elke cel valt. Op die manier blijft een inschatting van de totale populatiegrootte per jaar mogelijk en kan de verspreiding ook op de iets grovere schaal van het rooster bekeken worden.

\subsection{Permanente kwadraten}

In het kader van PINK werd een netwerk van ruim 300 permanente kwadraten (PQ's) met een oppervlakte van $3 \times 3 \mathrm{~m}^{2}$ uitgezet in de door ANB beheerde duingebieden aan de kust. Dit netwerk wordt overgenomen en verder uitgebouwd in het kader van het meetnet voor de Natura2000 habitatkwaliteitmonitoring (Westra et al. 2014). Ook binnen de golf van De Haan werden reeds 6 dergelijke proefvlakken uitgezet (figuur 2.1). In 2017 werd de vegetatie binnen deze plots door INBO opgenomen (met de Londo bedekkingsschaal) en werd een bodemstaal genomen in het kader van het HabNorm project. Het uitzetten of opnemen van bijkomende PQ's valt buiten het bestek van deze studie. Hier worden enkel de in 2017 gemaakte opnames kort besproken, samen met de resultaten van de bodemanalyses.

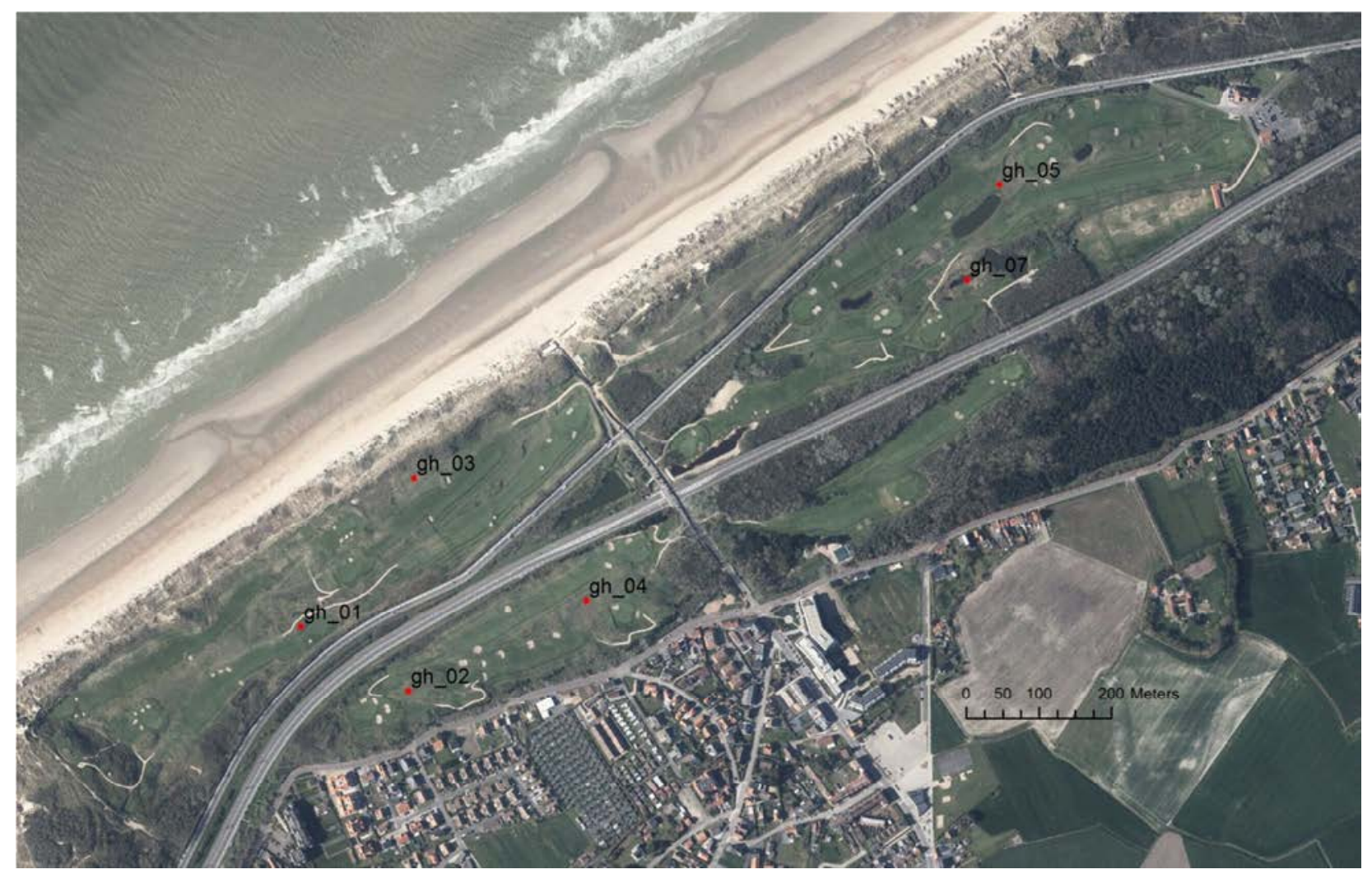

Figuur 2.1. Situering van de permanente vegetatieplots ( $P Q$ 's) op de Golf van De Haan 


\subsection{Vegetatiekartering}

De vegetatiekartering werd eveneens uitgevoerd volgens de PINK-methodiek. Al ruim 1500 ha duinen zijn volgens deze methode in kaart gebracht. De veldkartering gebeurt op afdrukken op foto-papier (op schaal 1/1500) van digitale luchtfoto's. Een zomerbeeld uit 2017 uitgegeven als orthofoto met een ruimtelijke resolutie van $25 \mathrm{~cm}$ door het agentschap Informatie Vlaanderen, vormt de basisfoto. Op deze veldkaart worden de contouren van vegetatie-eenheden afgebakend met fijne alcoholstiftjes en worden bijhorende codes genoteerd. De minimale gekarteerde eenheid is relatief klein (ca. $10 \mathrm{~m}^{2}$ ) en is afhankelijk van het type vegetatie. Zo kunnen bijvoorbeeld individuele bomen of struiken zoals meidoorns in een grasland gemakkelijk onderscheiden worden. Het werken met dergelijke kleine ruimtelijke eenheden laat toe een hoge graad van homogeniteit te bereiken binnen de polygonen, wat de precisie en herhaalbaarheid van de kartering ten goede komt.

Aan ieder polygoon van de kaart worden verschillende attributen toegekend. Het belangrijkste veld 'code' omvat de basiseenheid, gekozen uit een vaste set van een paar honderd codes (zie typologie in bijlage). Deze codes worden gegroepeerd tot een beperkt aantal klassen zoals bijvoorbeeld 'Duingrasland', 'Mosduin' of 'Ruigte'. Verdere precisering van de types gebeurt via de velden 'Dominant' en 'Subdominant', waarin de dominante en eventueel subdominante soorten worden aangeduid. De kartering van de golf werd uitgevoerd tijdens 6 veldwerkdagen tussen 17 augustus en 13 september 2018. Digitalisatie en verdere verwerking gebeurde in ArcGIS 10.

Vanuit de gedetailleerde vegetatiekaarten werd een vertaling gemaakt naar het niveau van de Europese Natura 2000 habitattypes. Hiervoor werden de polygonen samengebracht tot grotere eenheden met een min of meer homogene structuur. Als kleinste karteereenheid wordt een oppervlakte van $400 \mathrm{~m}^{2}$ aangehouden, conform de voorschriften van de karteermethode 'BioHab' die ontwikkeld werd voor het uniformiseren van habitatkarteringen in een Europese context (Bunce et al. 2008). 


\section{Resultaten}

\subsection{Detailkartering van aandachtssoorten}

\subsubsection{Algemeen}

De voorbije 15 jaar werden op de golf van De Haan 51 verschillende aandachtssoorten gevonden. Dat is bijna $20 \%$ van alle aandachtssoorten die aan de kust worden beschouwd. De gegevens zijn vooral verzameld in drie afzonderlijke perioden: bij de opmaak van het vorige beheerplan in 2003; in 2010 als ondersteuning biji de opmaak van het natuurrichtplan en bij de huidige kartering van 2018 (tabel 3.1). Figuur 3.1 geeft een beeld van de inventarisatie-inspanning aan de hand van de GPS track-log. Helaas is die door een technisch probleempje niet beschikbaar voor de hele kartering.

De resultaten van de verwerking van alle gegevens worden samengevat in tabel 3.2.

Tabel 3.1. Overzicht van de aantallen gekarteerde punten en vlakken in het golfterrein.

\begin{tabular}{|c|c|c|c|}
\hline Periode & JAAR & Aantal punten & Aantal vlakken \\
\hline \multirow{4}{*}{1} & 2003 & 479 & 1 \\
\hline & 2004 & 3 & \\
\hline & 2006 & 12 & \\
\hline & 2007 & 4 & \\
\hline \multirow{3}{*}{2} & 2008 & 97 & \\
\hline & 2009 & 1 & \\
\hline & 2010 & 459 & \\
\hline \multirow{2}{*}{3} & 2014 & 1 & \\
\hline & 2018 & 1007 & 23 \\
\hline
\end{tabular}

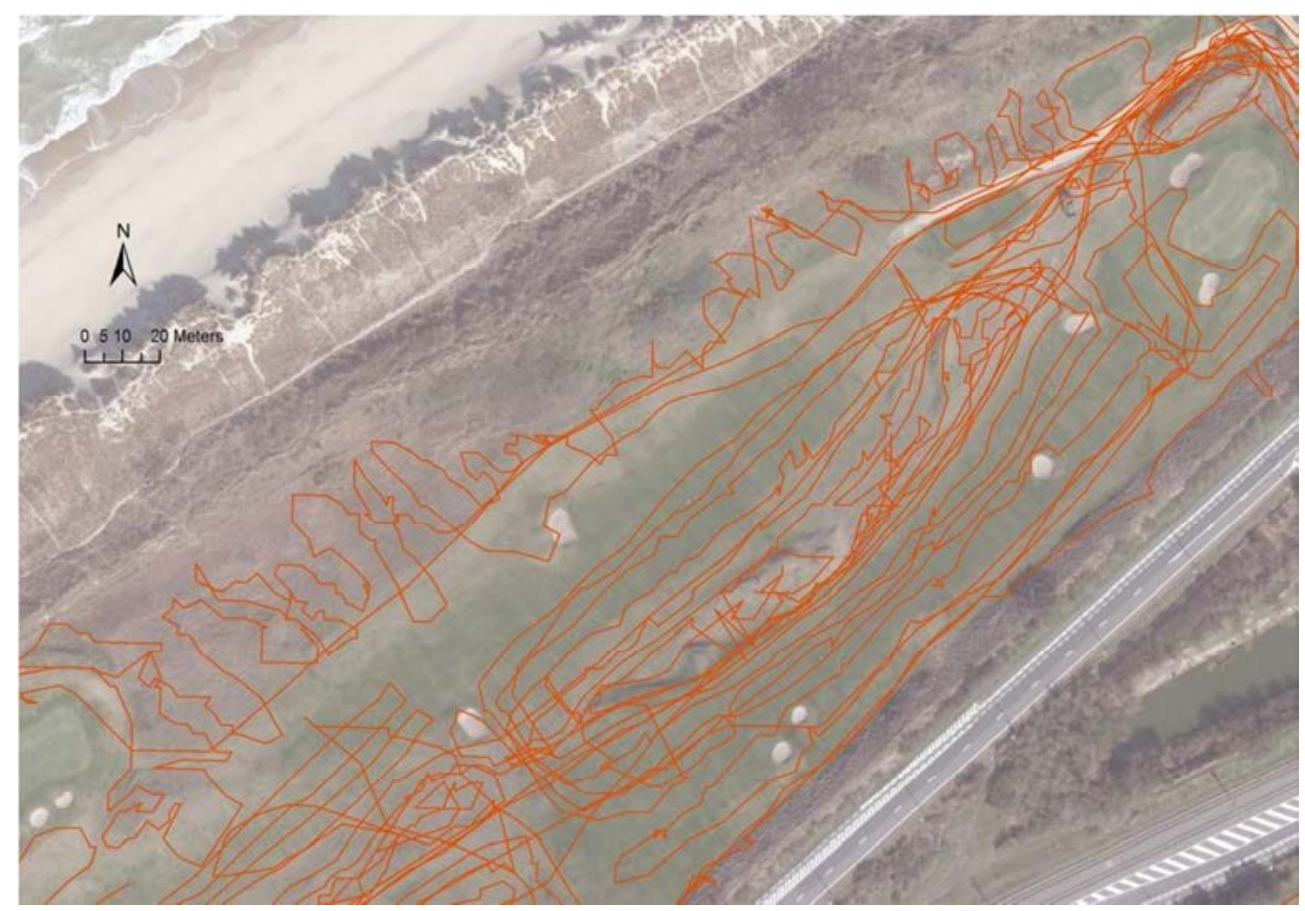

Figuur 3.1. Dit voorbeeld van de GPS track-log geeft een beeld van de inventarisatie-inspanning. 
Tabel 3.2. Aantal rastercellen van $25 \times 25 \mathrm{~m}^{2}$ warbinnen de aandachtssoorten in de verschillende periodes zijn aangetroffen met tussen haakjes de geschatte populatiegrootte in aantallen individuen of $m^{2}$ van de groeiplaats.

\begin{tabular}{|c|c|c|c|c|}
\hline & 2003 & $2008-2010$ & 2018 & \\
\hline Aantal soorten & 33 & 28 & 44 & \\
\hline Agrimonia eupatoria & $1(2-5)$ & $1(5-25)$ & $2(25-50)$ & Gewone agrimonie \\
\hline Aira caryophyllea & & & $2(500-5000)$ & Zilverhaver \\
\hline Anthyllis vulneraria & $24(50-500)$ & $19(50-500)$ & $27(50-500)$ & Wondklaver \\
\hline Aster tripolium & & & $1(1)$ & Zulte \\
\hline Briza media & & & $2(50-500)$ & Bevertjes \\
\hline Calystegia soldanella & $5(25-50)$ & $2(5-25)$ & $6(5-25)$ & Zeewinde \\
\hline Carex flacca & $8(25-50)$ & $1(5-25)$ & $30(500-5000)$ & Zeegroene zegge \\
\hline Carex spicata & & & $1(1)$ & Gewone bermzegge \\
\hline Carex trinervis & & & $5(5-25)$ & Drienervige zegge \\
\hline Carex $x$ timmiana & $1(50-500)$ & $1(50-500)$ & $1(50-500)$ & Drienervige $\mathrm{x} z$ warte zegge \\
\hline Carex viridula s.I. & & & $10(500-5000)$ & Dwergzegge \\
\hline Catapodium marinum & & & $1(50-500)$ & Laksteeltje \\
\hline Centaurium littorale & & & $3(25-50)$ & Strandduizendguldenkruid \\
\hline Crambe maritima & $2(2-5)$ & $1(2-5)$ & $1(2-5)$ & Zeekool \\
\hline Dactylorhiza incarnata & & & $6(50-500)$ & Vleeskleurige orchis \\
\hline Dactylorhiza praetermissa & & $1(2-5)$ & $1(2-5)$ & Rietorchis \\
\hline Danthonia decumbens & & $1(5-25)$ & $5(50-500)$ & Tandjesgras \\
\hline Erigeron acer & $6(50-500)$ & $4(5-25)$ & $12(25-50)$ & Scherpe fijnstraal \\
\hline Eryngium maritimum & $7(25-50)$ & $5(5-25)$ & $7(5-25)$ & Blauwe zeedistel \\
\hline Euphorbia cyparissias & $7(25-50)$ & $19(50-500)$ & $32(500-5000)$ & Cipreswolfsmelk \\
\hline Euphorbia esula & $2(25-50)$ & & $1(5-25)$ & Heksenmelk \\
\hline Helianthemum nummularium & $3(5-25)$ & $2(5-25)$ & $3(5-25)$ & Geel zonneroosje \\
\hline Himantoglossum hircinum & $83(500-5000)$ & $108(50-500)$ & $92(500-5000)$ & Bokkenorchis \\
\hline Isolepis setaceus & & $2(50-500)$ & $6(5-25)$ & Borstelbies \\
\hline Juncus foliosus & & & $2(50-500)$ & Gestreepte greppelrus \\
\hline Knautia arvensis & & $2(25-50)$ & $1(5-25)$ & Beemdkroon \\
\hline Leonurus cardiaca & $1(1)$ & & & Hartgespan \\
\hline Linum catharticum & $1(1)$ & $2(5-25)$ & & Geelhartje \\
\hline Medicago minima & $1(1)$ & & $1(50-500)$ & Kleine rupsklaver \\
\hline Mibora minima & $3(5-25)$ & & & Dwerggras \\
\hline Ophrys apifera & $3(2-5)$ & & & Bijenorchis \\
\hline Orobanche caryophyllacea & $2(5-25)$ & $3(2-5)$ & $4(5-25)$ & Walstrobremraap \\
\hline Orobanche purpurea & $6(5-25)$ & $1(2-5)$ & $5(5-25)$ & Blauwe bremraap \\
\hline Polygala vulgaris & $4(5-25)$ & $2(5-25)$ & $8(25-50)$ & Gewone vleugeltjesbloem \\
\hline Radiola linoides & $2(2-5)$ & & & Dwergvlas \\
\hline Rhinanthus angustifolius & $27(50-500)$ & $31(500-5000)$ & $49(500-5000)$ & Grote ratelaar \\
\hline Rhinanthus minor & $107(5000-50000)$ & $146(5000-50000)$ & $116(5000-50000)$ & Kleine ratelaar \\
\hline Sagina nodosa & & & $2(25-50)$ & Sierlijke vetmuur \\
\hline Sanguisorba minor & $3(5-25)$ & $2(5-25)$ & $2(5-25)$ & Kleine pimpernel \\
\hline Scirpus tabernaemontani & & & $3(5-25)$ & Ruwe bies \\
\hline Scleranthus annuus & $1(2-5)$ & & $16(500-5000)$ & Eenjarige hardbloem \\
\hline Sherardia arvensis & $2(2-5)$ & & $1(2-5)$ & Blauw walstro \\
\hline Silene conica & $12(50-500)$ & $3(25-50)$ & $5(50-500)$ & Kegelsilene \\
\hline Silene nutans & $2(5-25)$ & & & Nachtsilene \\
\hline Silene vulgaris & $2(2-5)$ & & & Blaassilene \\
\hline Thymus pulegioides & $52(50-500)$ & $50(50-500)$ & $54(50-500)$ & Grote tijm \\
\hline Torilis nodosa & & $2(5-25)$ & $1(5-25)$ & Knopig doornzaad \\
\hline Trifolium filiforme & $25(50-500)$ & $5(5-25)$ & $46(500-5000)$ & Draadklaver \\
\hline Trifolium scabrum & $71(500-5000)$ & $49(500-5000)$ & $280(5000-50000)$ & Ruwe klaver \\
\hline Trifolium striatum & $24(50-500)$ & $17(500-5000)$ & $171(5000-50000)$ & Gestreepte klaver \\
\hline Trifolium subterraneum & & & $5(5-25)$ & Onderaardse klaver \\
\hline
\end{tabular}




\subsubsection{Bespreking per soort}

(Een aantal foto's werd ontleend aan de Saxifraga foundation - freenatureimages.eu)

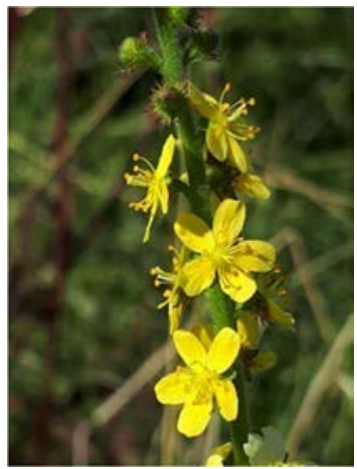

Gewone agrimonie Agrimonia eupatoria

RL: Achteruitgaand

Geschatte kustpopulatie: 500-5000 ind.

Geschatte populatie Golf: $25-50$ ind.

Groeit in graslanden en zomen op vochtige tot droge, kalkhoudende bodems. Aan de kust is gewone agrimonie het meest talrijk in de (omgeving van de) Zwinduinen. Verder wordt de soort aangetroffen in de Westhoek en verspreid langs de hele kust. In de golf worden enkele tientallen exemplaren aangetroffen in de roughs van hole 10. De populatie lijkt zich geleidelijk uit te breiden.

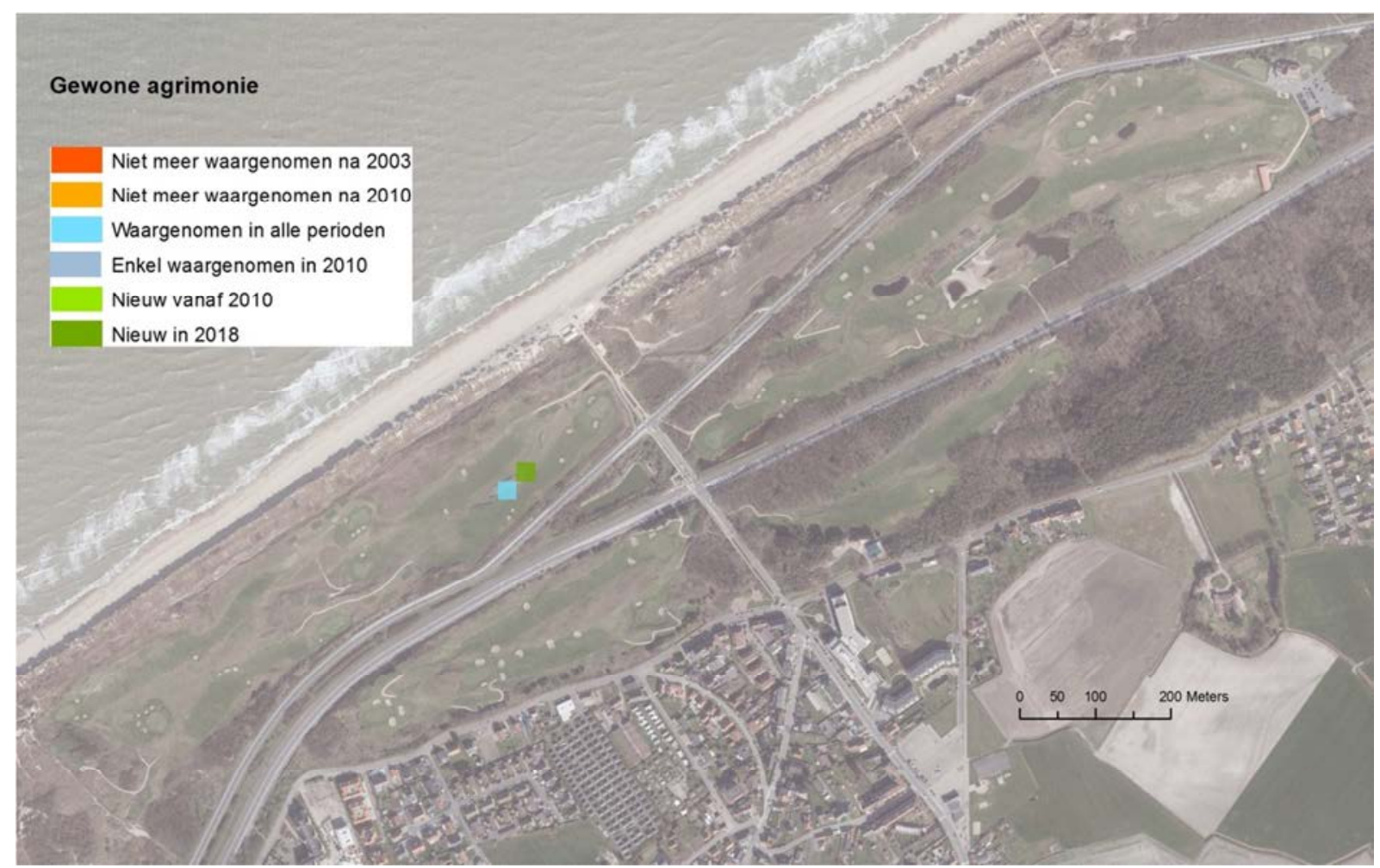




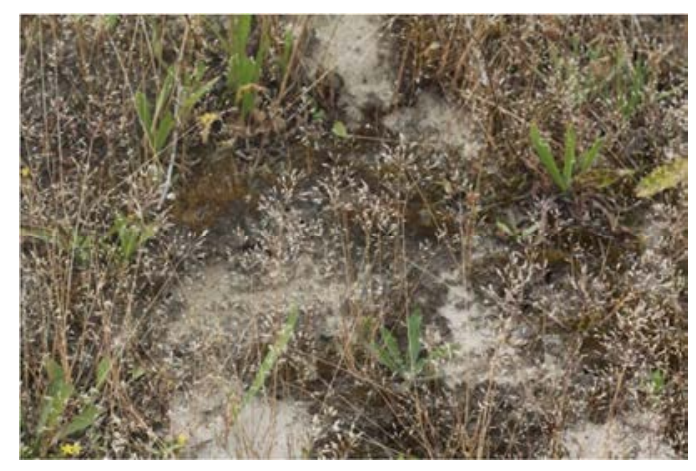

\section{Zilverhaver Aira caryophyllea}

RL: Momenteel niet bedreigd

Geschatte kustpopulatie: 500-5000 ind.

Geschatte populatie Golf: 500-5000 ind.

Eénjarige soort van zwak zure pioniermilieus, in Vlaanderen vooral te vinden op de zure zandgronden. In de duinen wijst de aanwezigheid doorgaans op oppervlakkige bodemontkalking. Zilverhaver wordt verspreid over de hele kust waargenomen, doorgaans in kleine aantallen. In de golf werd in 2018 een grote groeiplaats vastgesteld van meerdere honderden individuen tussen de tees van holes 8 en 9.

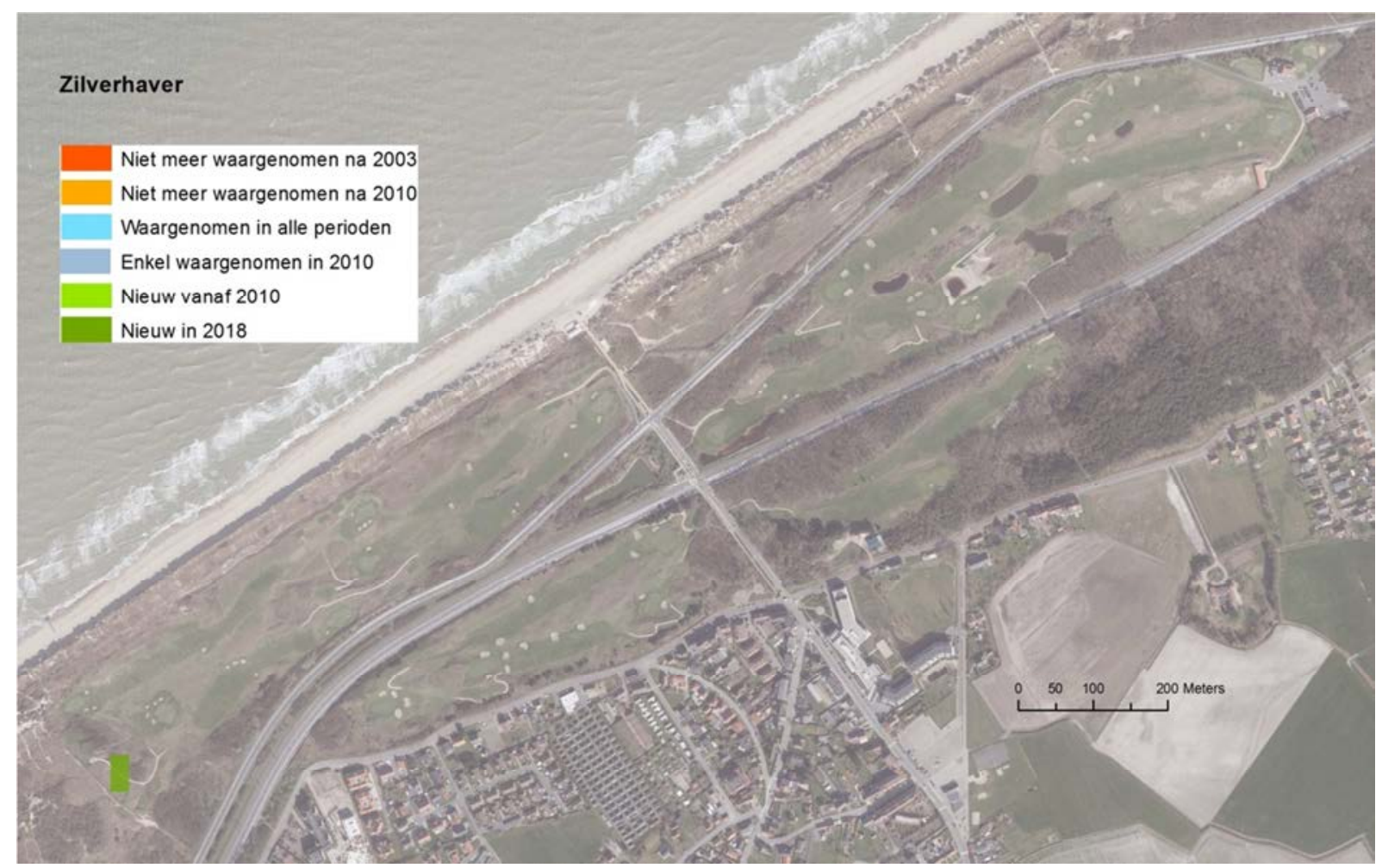




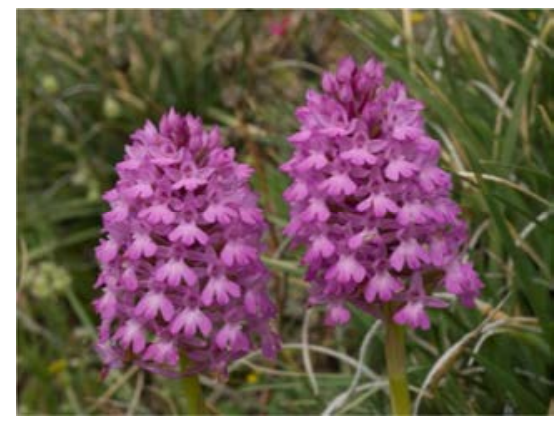

Hondskruid Anacamptis pyramidalis

\author{
RL: Zeldzaam
}

Geschatte kustpopulatie: 5-50 ind.

Geschatte populatie Golf: -

Hondskruid is een in Vlaanderen zeer zeldzame soort van droge, schrale en kalkrijke graslanden. Aan onze kust recent van hooguit 10 groeiplaatsen bekend en nergens lang standhoudend. In duingebieden in het buitenland (o.m. Nederland, Frankrijk en Ierland) komt de soort nochtans lokaal in grotere aantallen voor. Van de golf zijn geen recente waarnemingen bekend. Wel werd de soort in 2006 aangetroffen in de berm van de Koninklijke Baan ter hoogte van de golf.

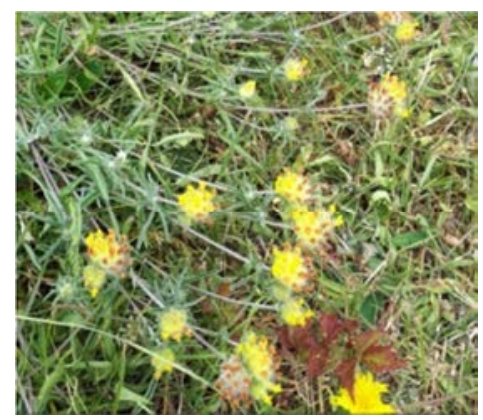

Wondklaver Anthyllis vulneraria

\title{
RL: Kwetsbaar
}

Geschatte kustpopulatie: 5000-50 000 ind.

Geschatte populatie Golf: 50-500 ind.

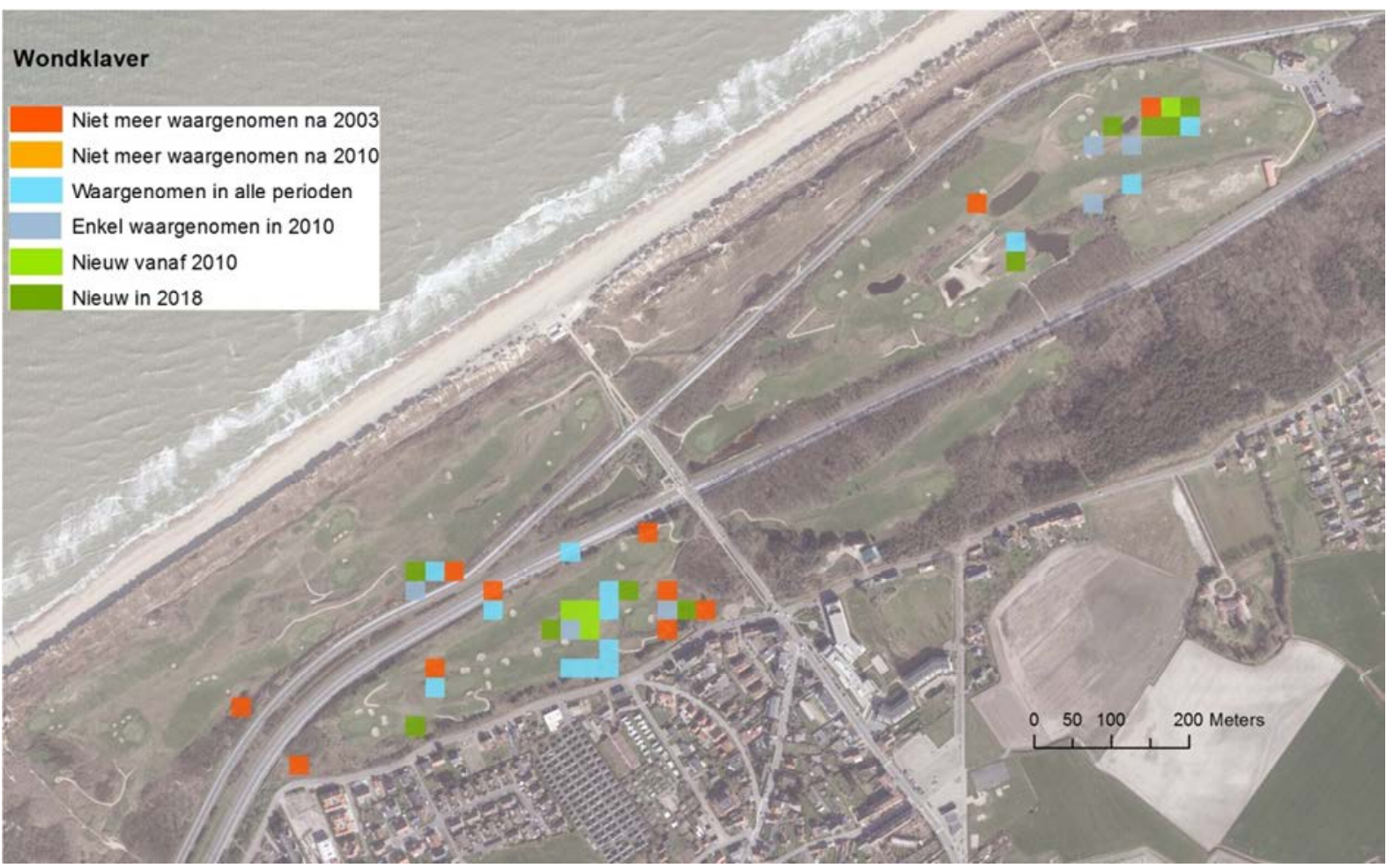


Een soort van kalkrijke graslanden die in Vlaanderen vooral in de duinen te vinden is. Daar heeft de soort een voorkeur voor fixerende stuifduinen en pionierduingraslanden. Komt verspreid over de hele kust voor met actueel een duidelijk zwaartepunt in De Panne. De grootste populaties (met honderden exemplaren) zijn zeer recente vestigingen die zich enerzijds situeren in de Zwarte hoek (voormalig zanddepot) en anderzijds in een fixerend deel van het loopduin in de Westhoek. In het laatste geval is er bijna zeker sprake van een vestiging uit een oude zaadvoorraad gezien de massale kieming op zeer korte termijn. Andere belangrijke groeiplaatsen zijn de duinen van Middelkerke (Warandeduinen) en de golfterreinen van De Haan en Knokke. De populatie op de golf lijkt de voorbije 15 jaar globaal min of meer stabiel te zijn in omvang met een vrij aanzienlijke ruimtelijke dynamiek van lokaal opduiken en weer verdwijnen van groeiplaatsen.

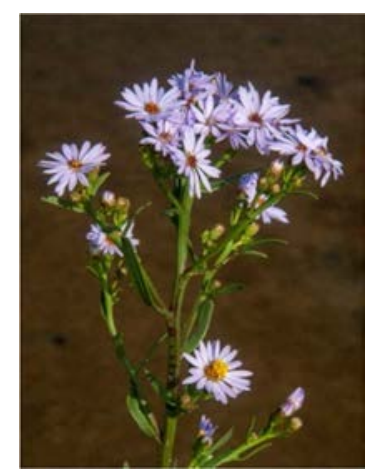

\section{Zulte Aster tripolium}

RL: Momenteel niet bedreigd

Geschatte kustpopulatie: > 50000 ind.

Geschatte populatie Golf: 1 ind.

Een soort van zilte en brakke omstandigheden die in Vlaanderen in schorren, zilte graslanden en op opgespoten terreinen te vinden is. Groeit aan de kust in hoofdzaak buitendijks in de IJzermonding, de Baai van Heist en (vooral) het Zwin. Op de golf dook de soort op in de afgraving ten zuiden van hole 4. Dit gebeurt wel vaker bij natuurontwikkeling aan de kust. Doorgaans zijn dergelijke zoete groeiplaatsen geen lang leven beschoren.

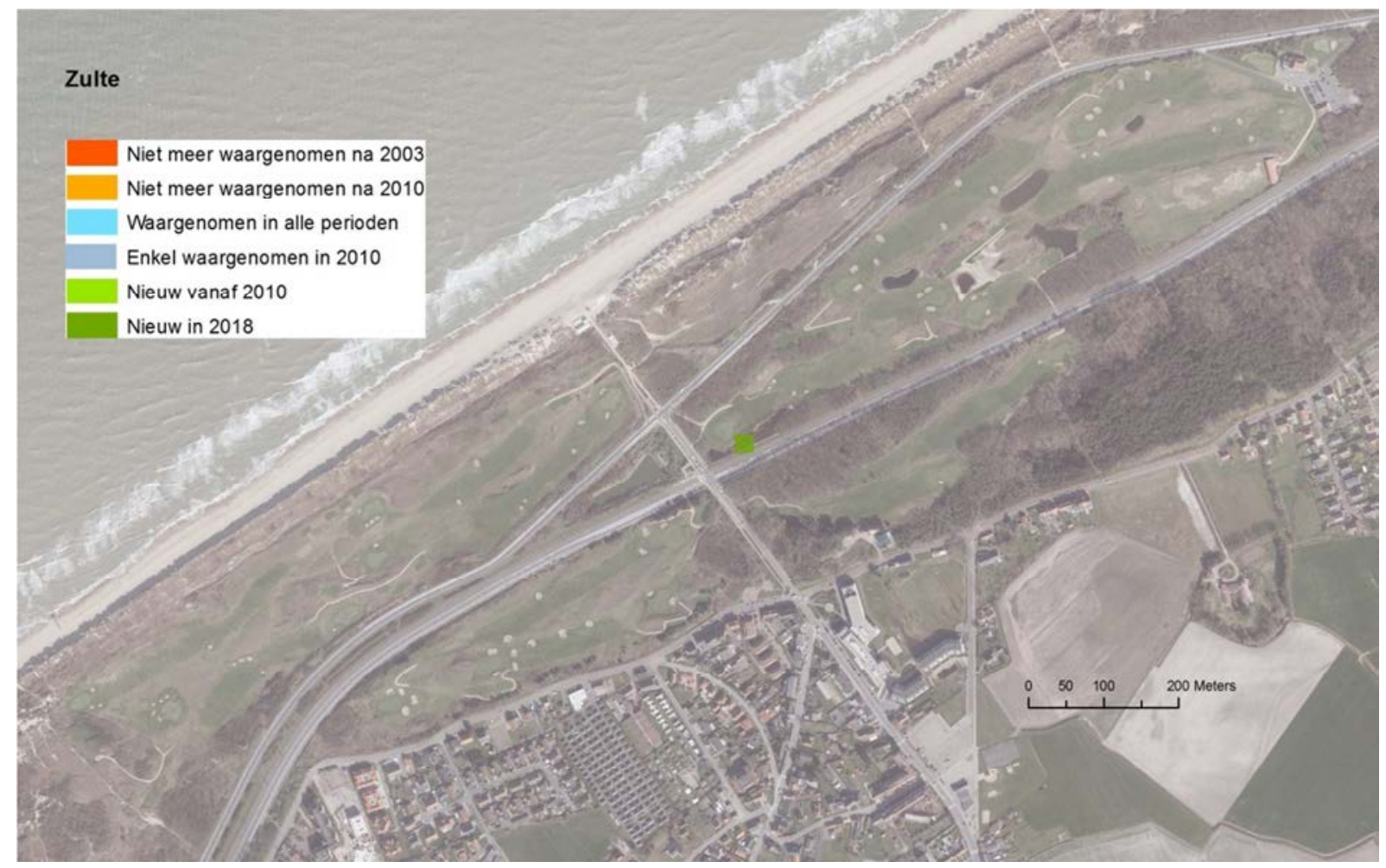




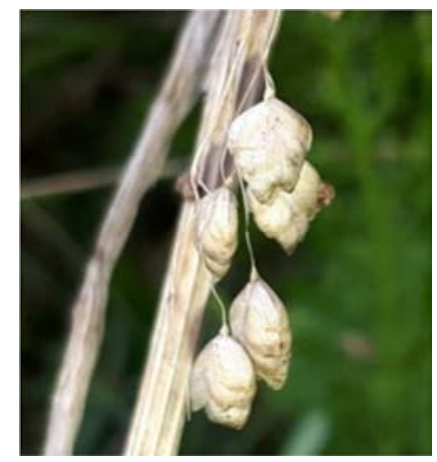

\section{Bevertjes Briza media}

RL: Kwetsbaar

Geschatte kustpopulatie: 5000-50 000 ind.

Geschatte populatie Golf: 50-500 ind.

Een soort van diverse types voedselarme graslanden die in Vlaanderen sterk achteruit gaat. Bevertjes komt voor in verschillende duingebieden verspreid over de hele kust met een belangrijke stronghold in de Westhoek. In de golf werd de soort in 2018 op twee verschillende locaties aangetroffen. Vermoedelijk werd bevertjes eerder over het hoofd gezien, de soort staat namelijk niet bekend als een vlotte verbreider. Verboven (1980) vermeldt de soort van een andere locatie binnen de gold, namelijk zijn opname 16, ter hoogte van de green van hole 15.

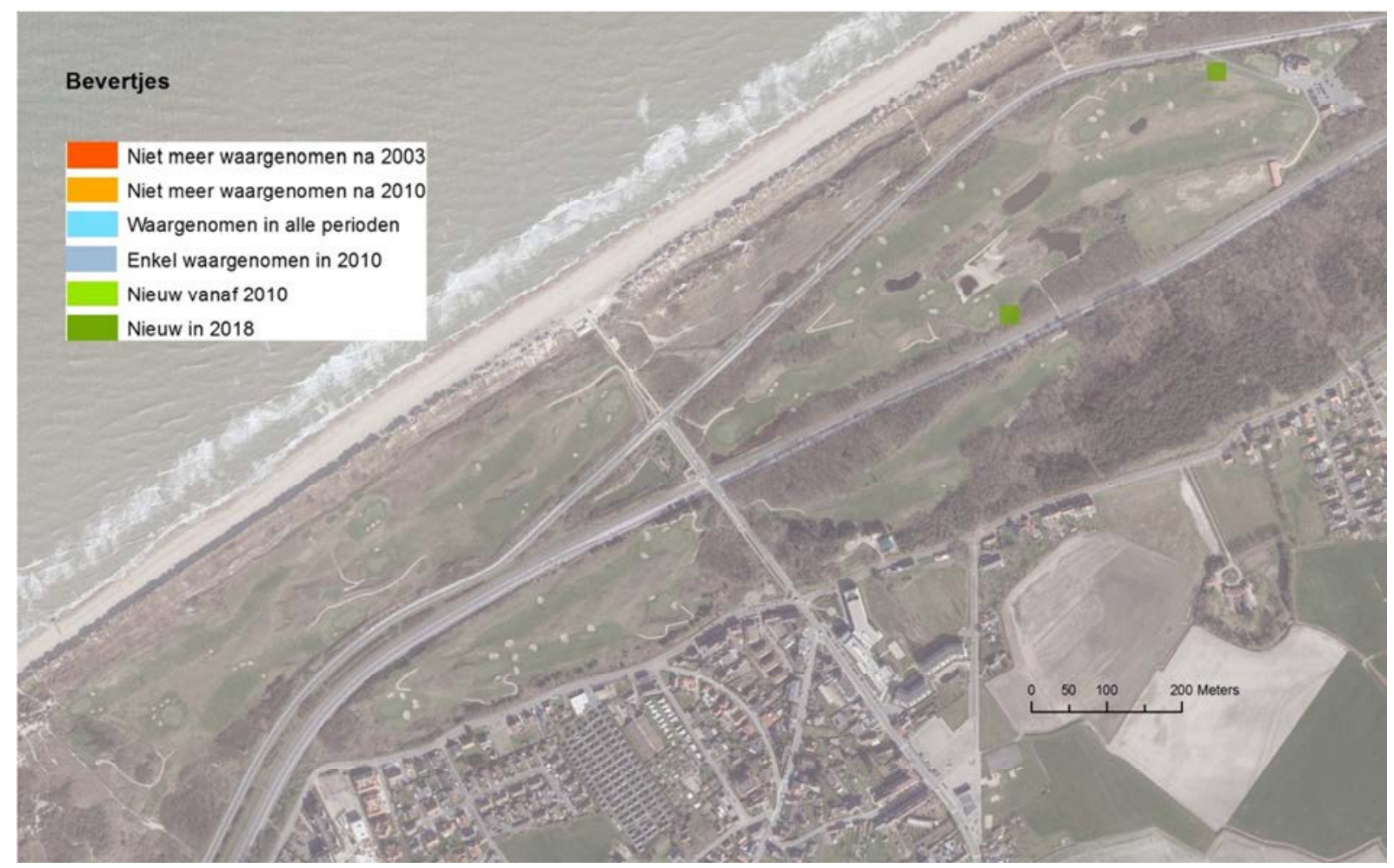




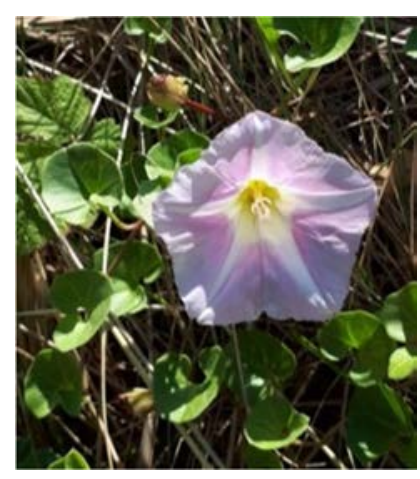

Zeewinde Calystegia soldanella

RL: Zeldzaam

Geschatte kustpopulatie: 5000-50 $000 \mathrm{~m}^{2}$

Geschatte populatie Golf: 5-25 $\mathrm{m}^{2}$

Een soort van de zeereep, optimaal groeiend in enigszins gefixeerde helmduinen. Verspreid over de hele kust te vinden maar met een duidelijk zwaartepunt aan de middenkust tussen Middelkerke en Wenduine. De groeiplaatsen op de golf maken hier deel van uit maar zij vormen slechts de marginale delen van een grote populatie in de zeereep.

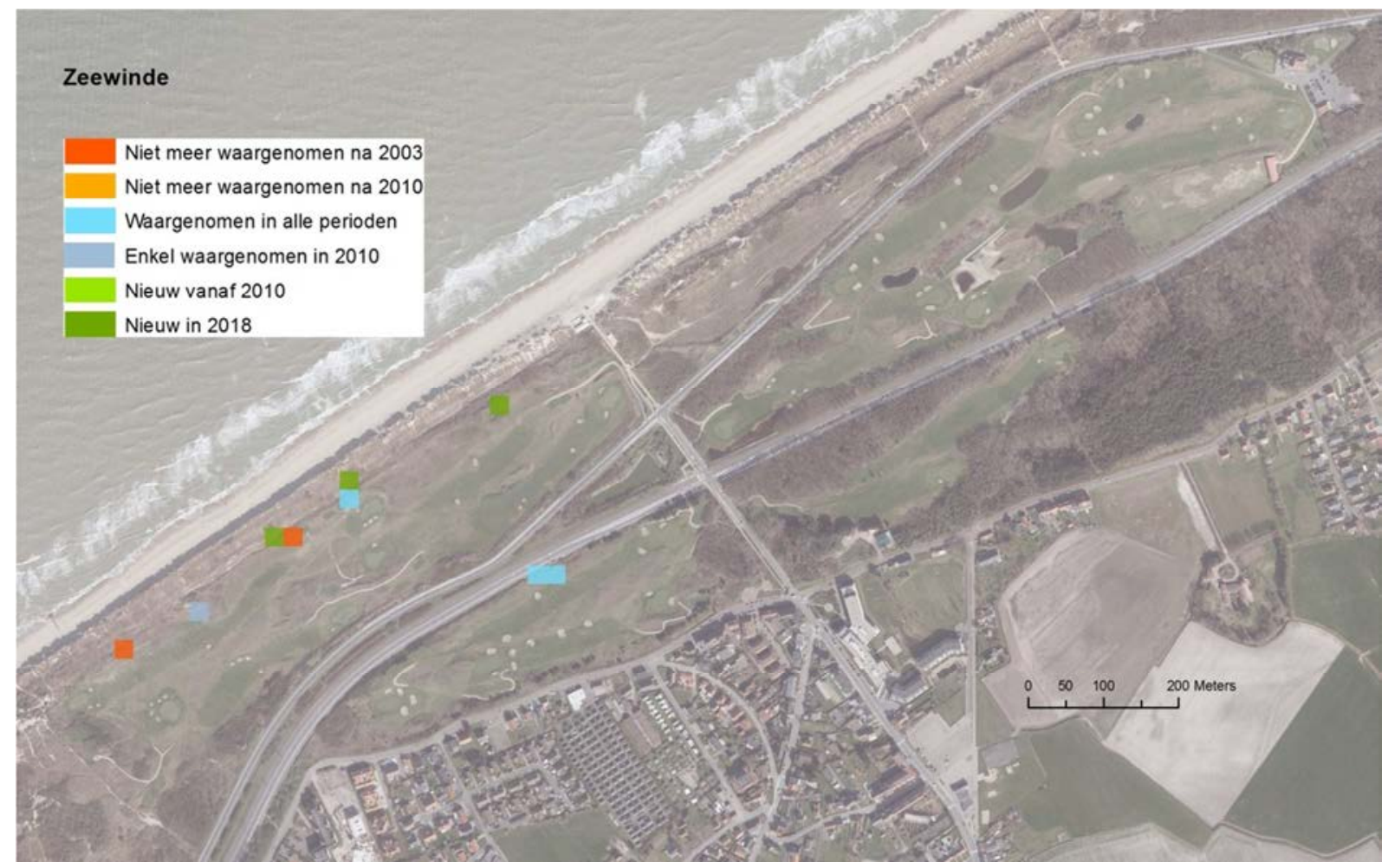




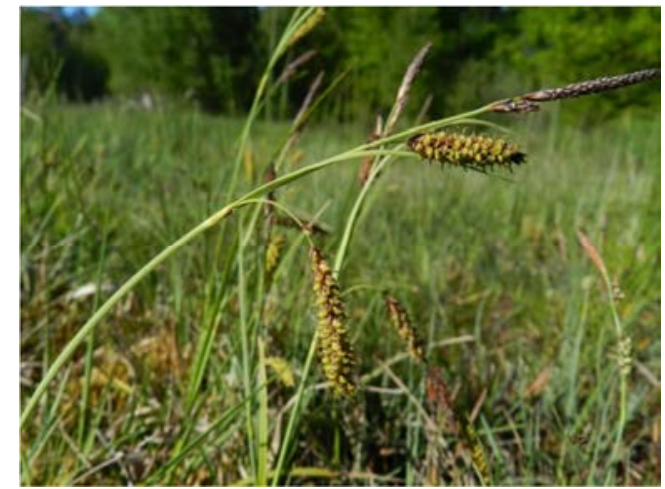

\section{Zeegroene zegge Carex flacca}

RL: Momenteel niet bedreigd

Geschatte kustpopulatie: onbekend (niet systematisch gekarteerd)

Geschatte populatie Golf: $500-5000 \mathrm{~m}^{2}$

Een soort van schrale graslanden die in de duinen zowel in natte duinvalleien als droge kalkrijke graslanden te vinden is. Verspreid over de hele kust maar met een zwaartepunt in de gebieden met grote duinvalleien zoals De Westhoek en Ter Yde. Op de golf is de soort sterk toegenomen, vooral door de natte natuurontwikkeling. In de droge duingraslanden is zeegroene zegge weinig opvallend en daardoor mogelijk bij eerdere karteringen over het hoofd gezien.

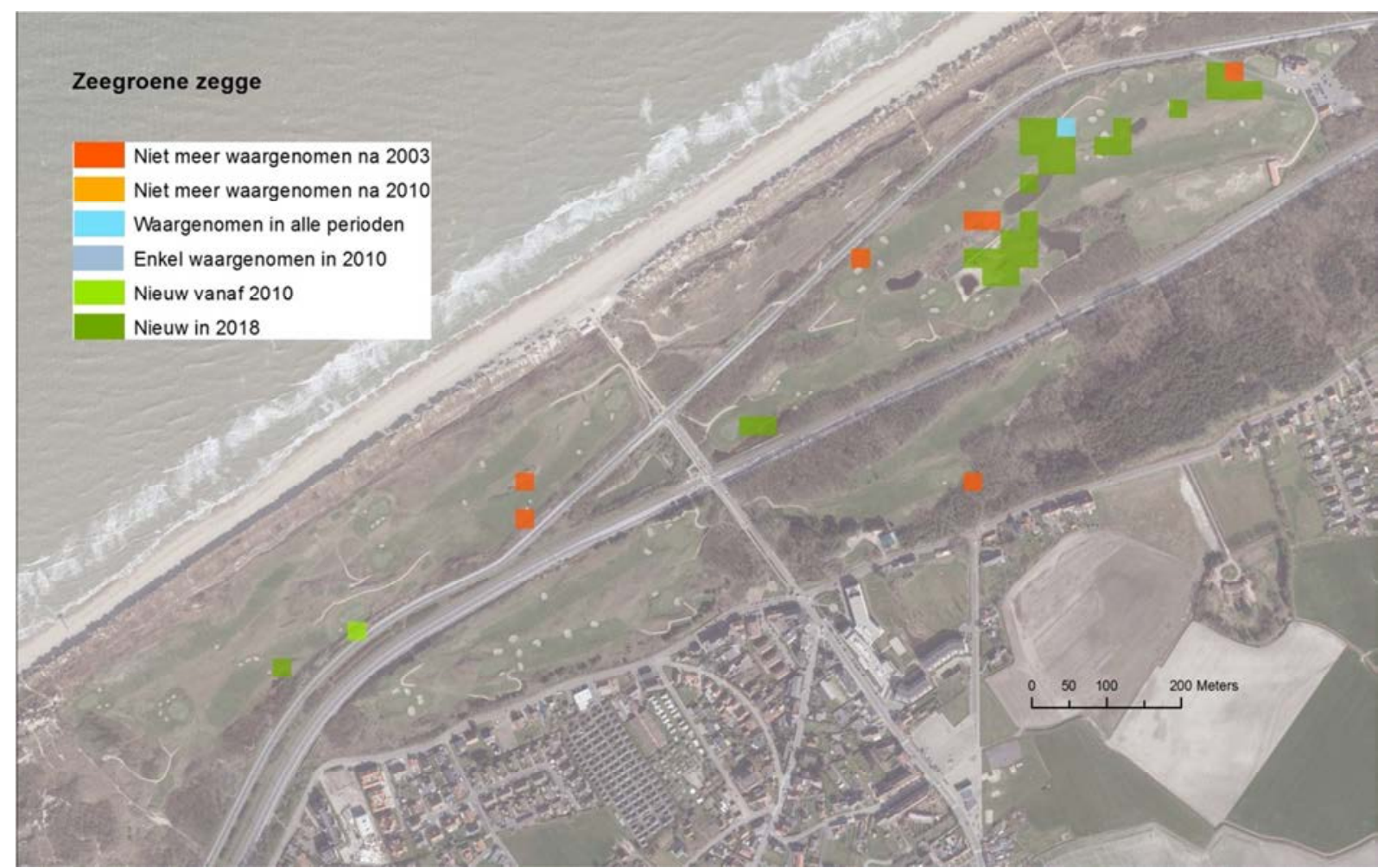




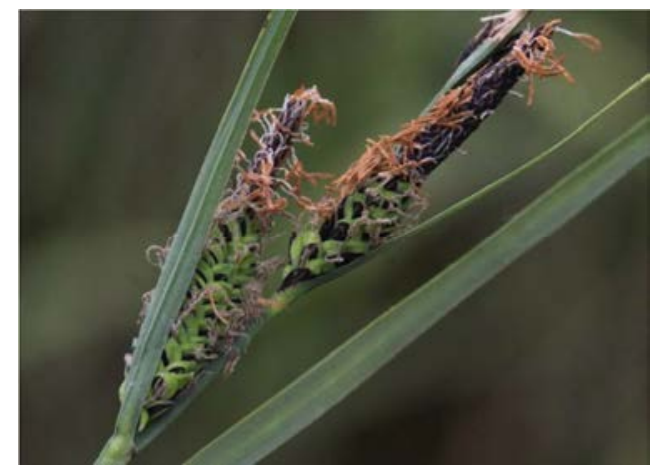

Drienervige zegge Carex trinervis (incl. C. $x$ timmiana)

\author{
RL: Zeldzaam
}

Geschatte kustpopulatie: 5000-50 $000 \mathrm{~m}^{2}$

Geschatte populatie Golf: $50-500 \mathrm{~m}^{2}$

Ondanks de eerder 'bescheiden' Rode lijststatus verdient de soort bijzondere aandacht gezien het internationaal belang ervan als Westeuropees kustendeem (Foley 2005). Het is vooral een duinvalleisoort maar eens gevestigd kan de plant bijzonder lang standhouden in verdroogde omstandigheden, bijvoorbeeld bij geleidelijke overstuiving. Drienervige zegge is vrij frequent aan te treffen aan de Westkust, met name in de duinvalleien van de Westhoek en Ter Yde. Verder komt de soort verspreid voor, onder meer ook in de droge, ontkalkte graslanden van Cabour, de Schudebeurze en Dheye. Op de golf groeit de soort in verschillende duinvalleitjes. Op twee groeiplaatsen betreft het recente vestigingen na afgraven ten behoeve van natuurontwikkeling, hoogstwaarschijnlijk vanuit de bodemzaadvoorraad. De groeiplaats ter hoogte van hole 1 (een vlek van ca. $100 \mathrm{~m}^{2}$ ) is al langer bekend. Het betreft hier echter de hybride tussen drienervige en zwarte zegge, Carex x timmiana. De grasgroene bladkleur en urntjes met een lengte van ca. $3 \mathrm{~mm}$ doen denken aan zwarte zegge maar de stompe halm en huidmondjes aan beide zijden van het blad pleiten eerder voor C. timmiana (figuur 3.2).

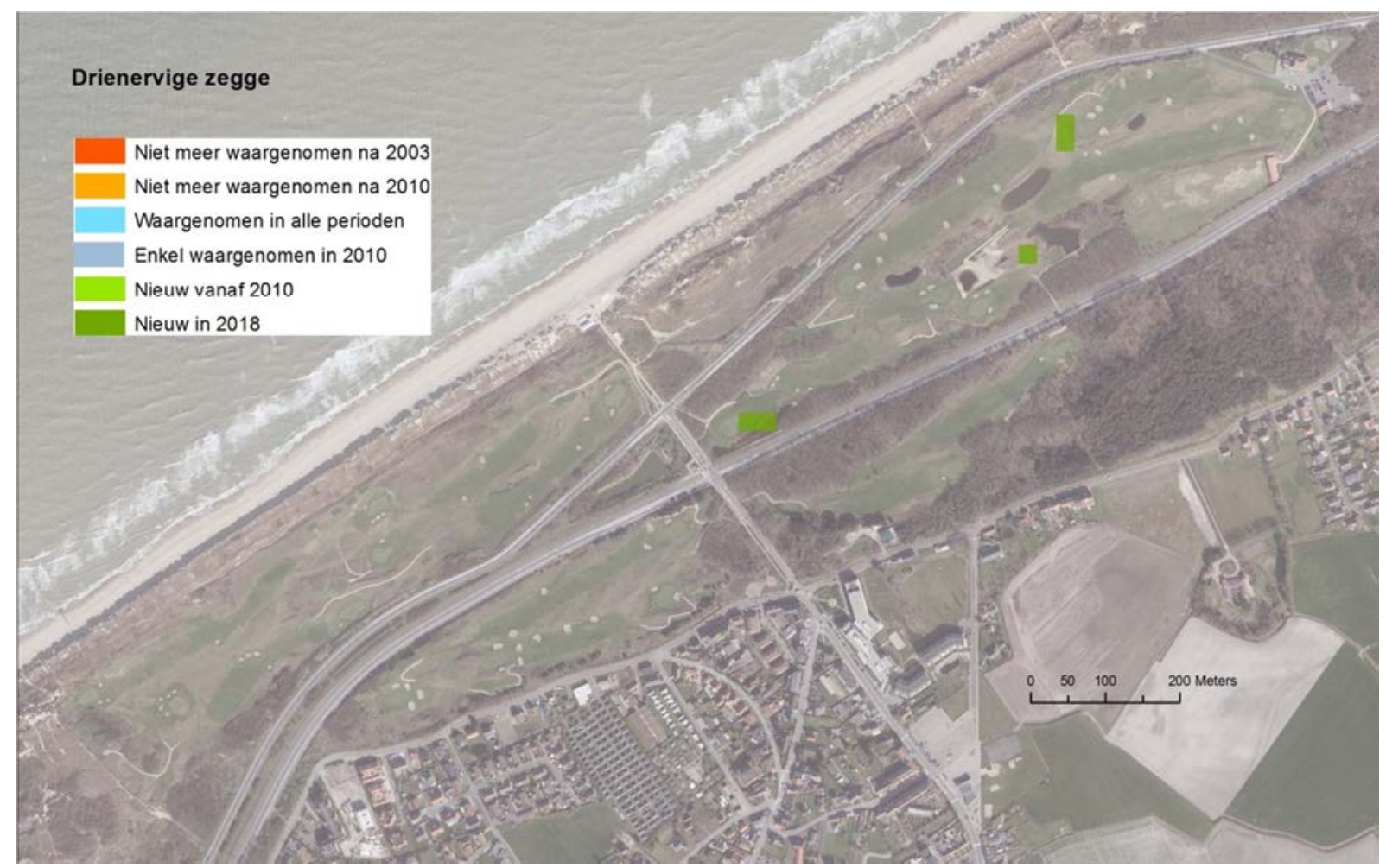



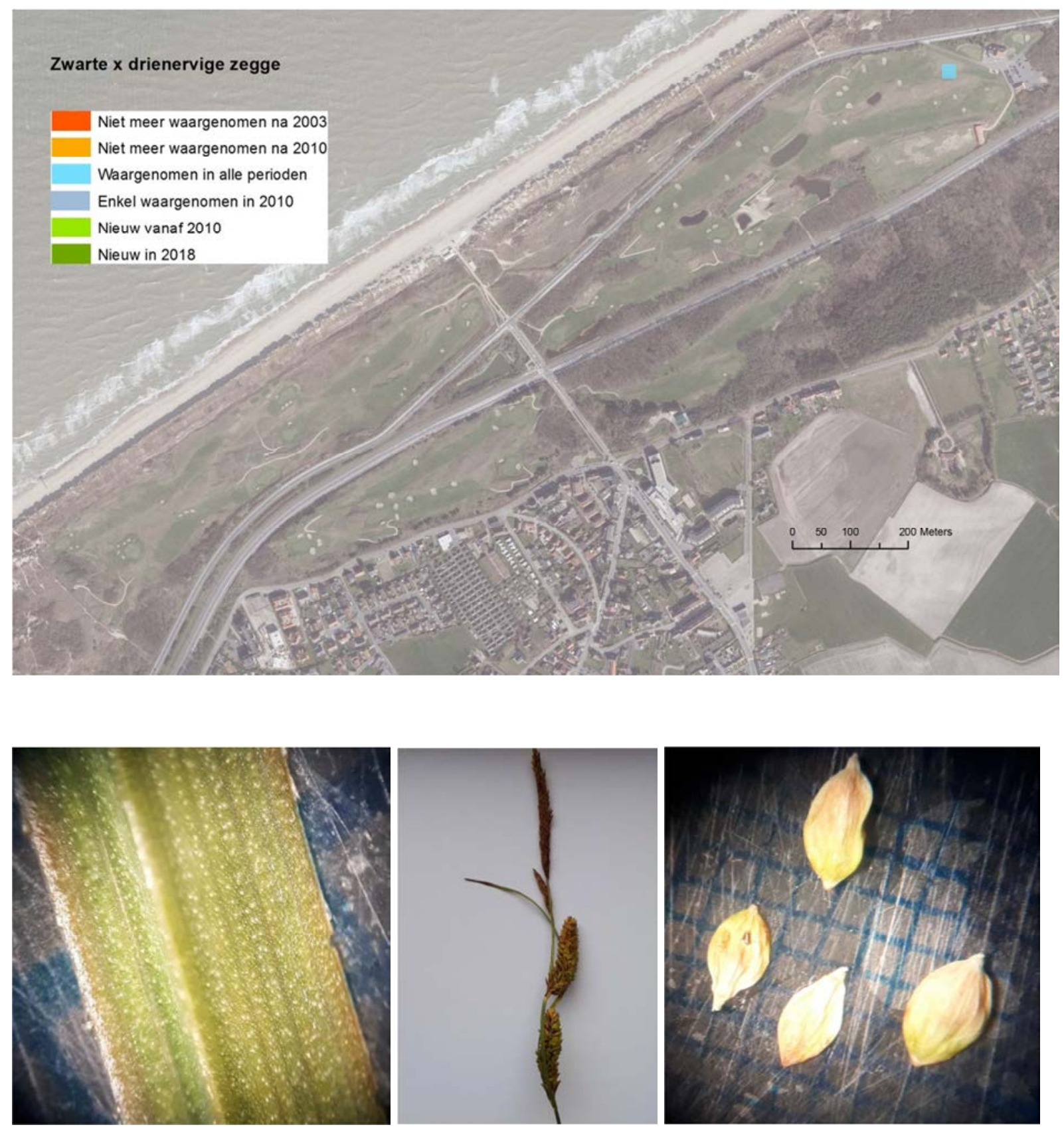

Figuur 3.2. Kenmerken van Carex $x$ timmiana: huidmondjes op zowel boven- als onderzijde van het blad (links), stompe halm (midden) en urntjes ca. $33 \mathrm{~mm}$ lang (rechts). 


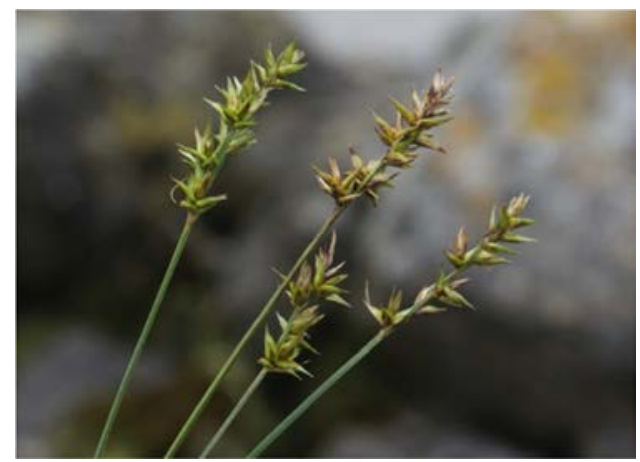

\section{Gewone bermzegge Carex spicata}

RL: Momenteel niet bedreigd

Geschatte kustpopulatie: 50-500 ind.

Geschatte populatie Golf: 1 ind.

Een soort van enigszins verstoorde graslanden. Bermzegge is een zeldzame verschijning in het westen van Vlaanderen. Aan de kust is de soort bekend van een handvol locaties aan de Westkust, D'Heye en de Zwinduinen, waar het leeuwendeel van de exemplaren groeit. Op de golf is één exemplaar waargenomen ter hoogte van hole 7.

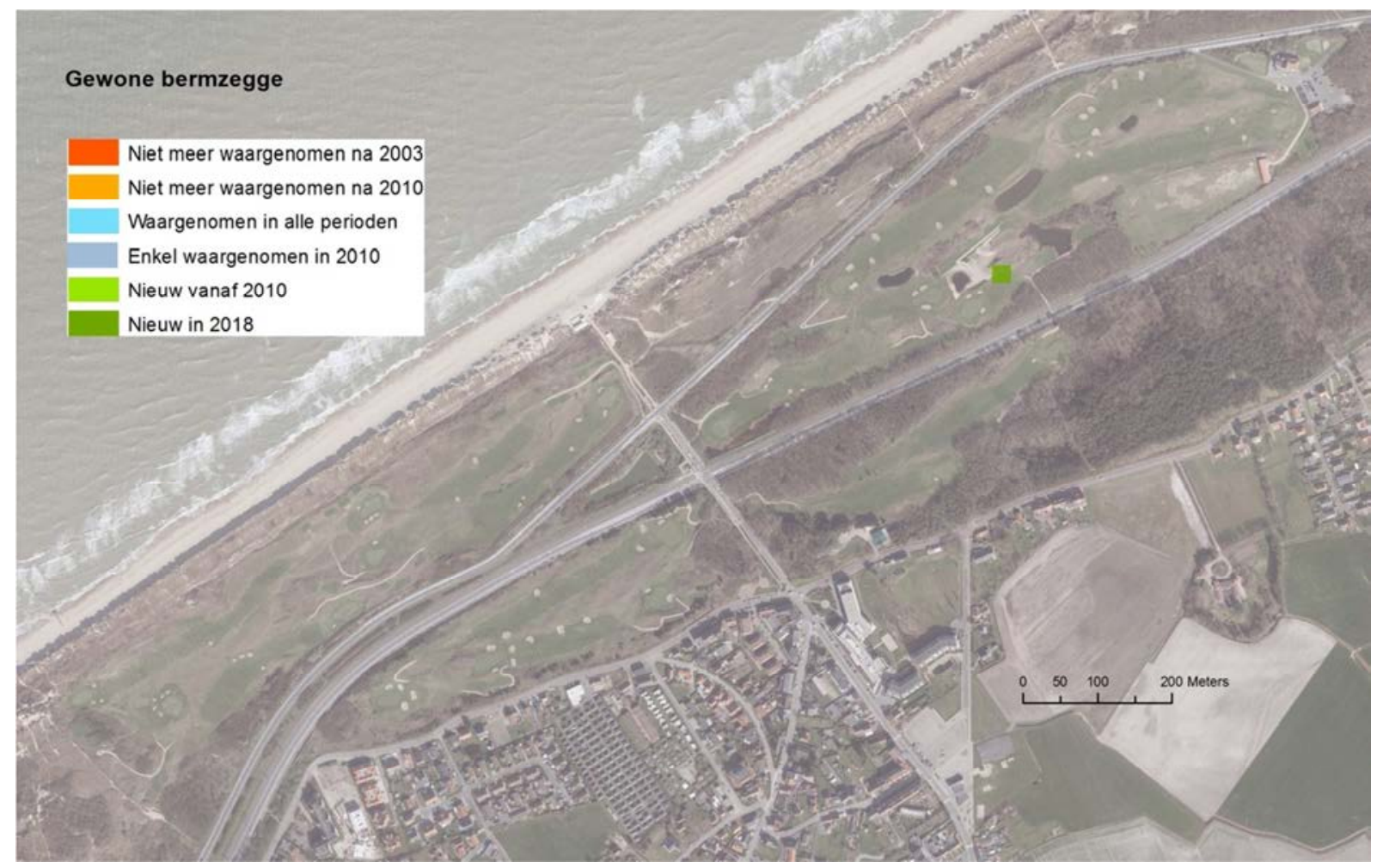




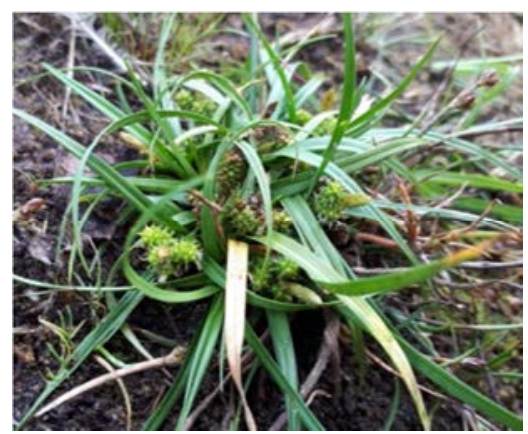

\section{Dwergzegge Carex viridula s.l.}

\section{RL: Bedreigd}

Geschatte kustpopulatie: > 50000 ind.

Geschatte populatie Golf: 500-5000 ind.

Rond dit taxon bestaat heel wat taxonomische discussie wat zich bijvoorbeeld uit in het groot aantal synoniemen. We houden het hier daarom op $C$. viridula sensu lato. Dwergzegge is een soort van open, korte kruidachtige vegetaties op natte, zwak zure tot basische bodems. Het is een vrij algemene soort in jonge duinpannen die tot op het grondwaterniveau zijn uitgestoven, op vochtige plagplekken of andere open plekken in oude duinvalleien. Ca. $90 \%$ van de kustpopulatie groeit in het noordelijk deel van de Westhoek. Ook in Ter Yde is de soort goed vertegenwoordigd en verder komt ze verspreid voor in de duinvalleien van de west- en de oostkust. De soort is bijzonder schaars in de duinen tussen Westende en Zeebrugge. De Golf van De Haan vormt er actueel één van de weinige gekende groeiplaatsen. De soort dook er op na de natuurontwikkelingswerken ten zuiden van hole 4 en ten noorden van hole 17, bijna zeker vanuit de bodemzaadvoorraad. Ook op de andere groeiplaatsen in deze zone, betreft het vestigingen na natuurontwikkelingsmaatregelen. Dwergzegge is historisch bekend van het gebied maar tijdens de inventarisaties tussen 2003 en 2010 niet meer aangetroffen. De soort wordt ook niet vermeld door Verboven 1980.

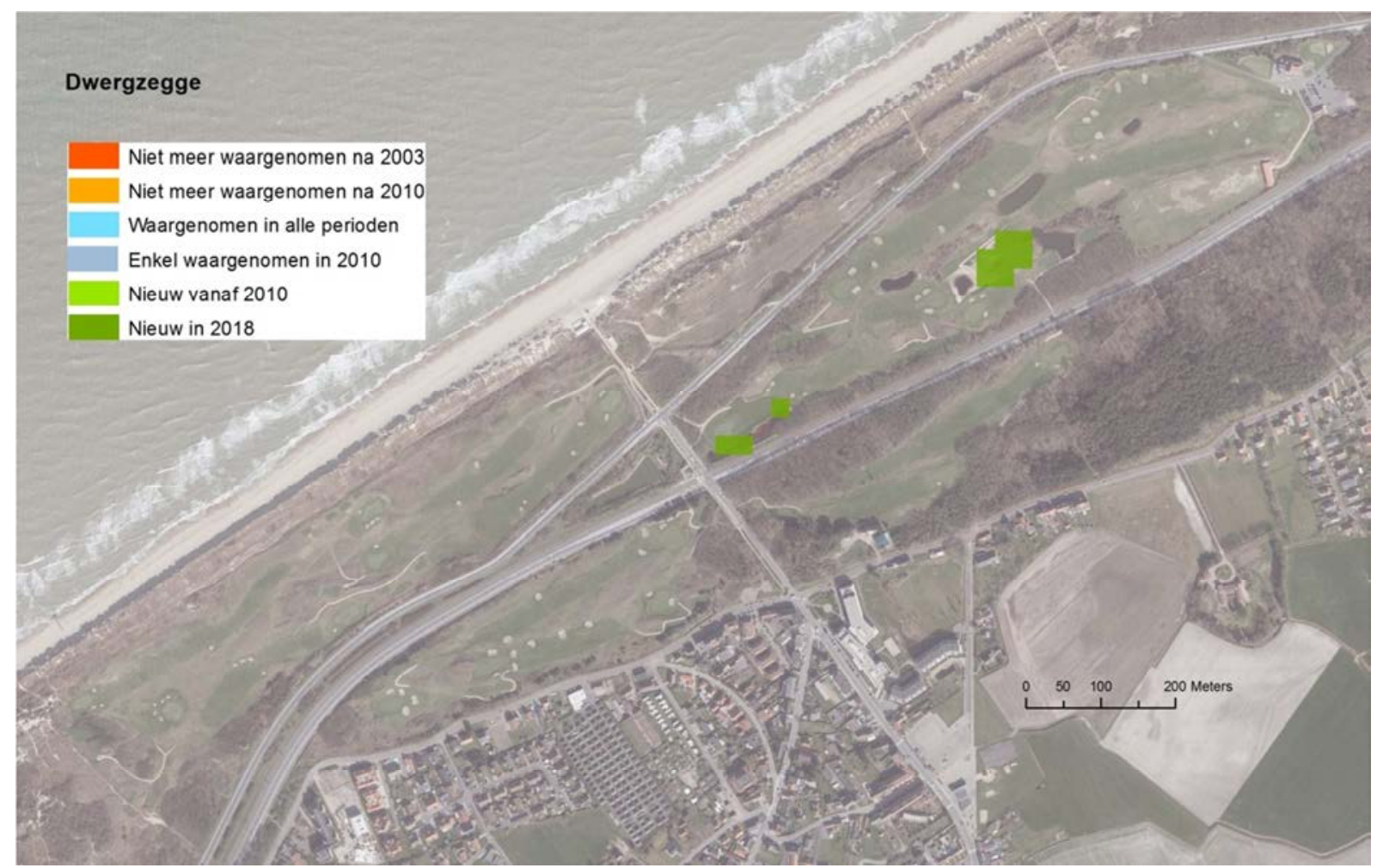




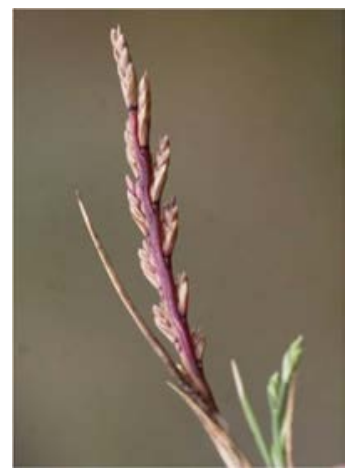

\section{Laksteeltje Catapodium marinum}

RL: Zeldzaam

Geschatte kustpopulatie: >50 000 ind.

Geschatte populatie Golf: 50-500 ind.

Een soort van droge pioniermilieus nabij de zee zoals zandige hoge schorren en kliffen. Ook in Vlaanderen is laksteeltje strikt kustgebonden maar de soort wordt er vaak in antropogene milieus aangetroffen (langs de kustbaan bijvoorbeeld). De Baai van Heist vormt met voorspong de grootste groeiplaats. De soort is pas in 1977 voor het eerst in ons land waargenomen en lijkt zich sterk uit te breiden (Goetghebeur 1977; Zwaenepoel et al. 1994). Op de golf werden droge restanten van enkele tientallen exemplaren aangetroffen ter hoogte van hole 10.

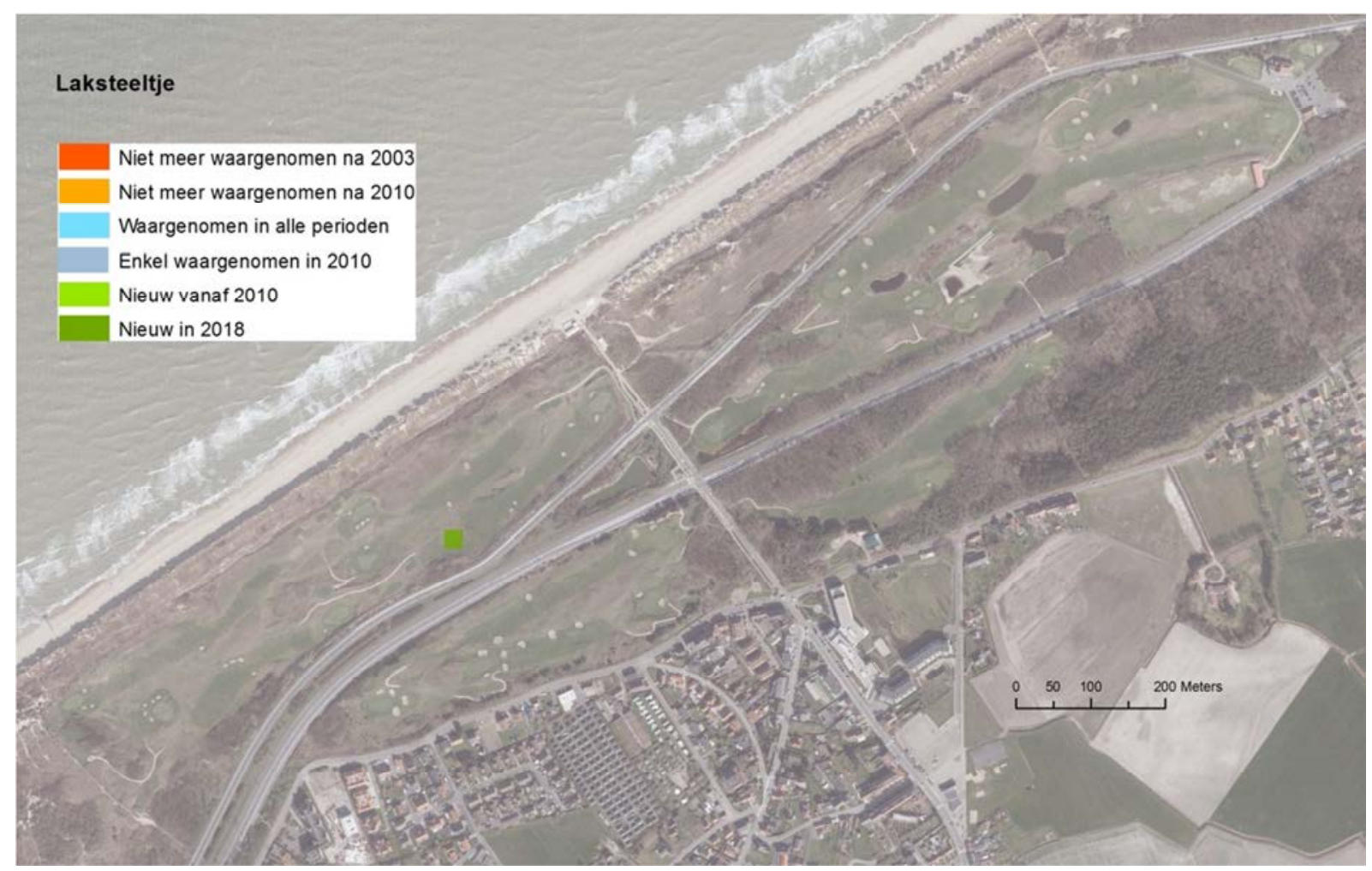




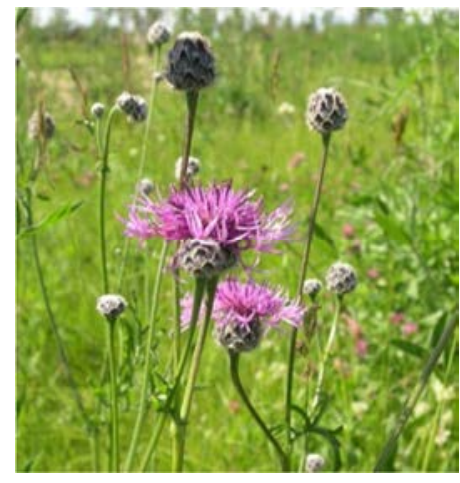

\title{
Grote centaurie Centaurea scabiosa
}

\author{
RL: Zeldzaam
}

Geschatte kustpopulatie: 5000-50 000 ind.

Geschatte populatie Golf: -

Een soort van droge, voedselarme en kalkhoudende (open) graslanden. In Vlaanderen is de soort zeldzaam. De meeste groeiplaatsen zijn gelegen in Haspengouw, de Maasvallei en de Voerstreek. Aan de kust zijn alle vindplaatsen gelegen in het grensgebied van Bredene en De Haan. De soort groeit er vooral in de brede wegbermen van de Koninklijke Baan, samen met andere soorten van het Glanshaververbond zoals margriet en beemdkroon. Het is onduidelijk wat de oorsprong is van deze populatie maar gezien de geïsoleerde ligging is tuinontsnapping niet onwaarschijnlijk. Grote centaurie werd nog niet op de golf zelf waargenomen maar vestiging vanuit de nabijgelegen groeiplaatsen is niet onwaarschijnlijk.

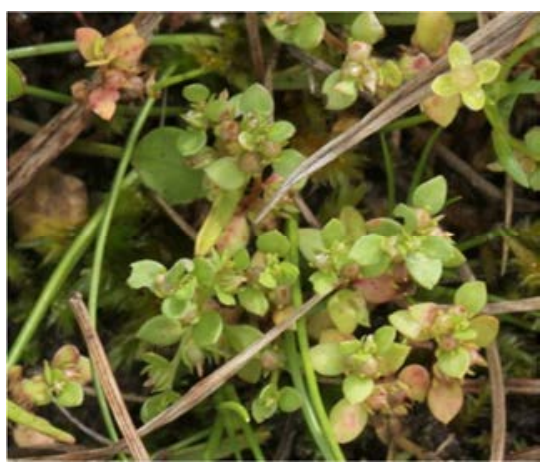

Dwergbloem Centunculus minimus

RL: Bedreigd

Geschatte kustpopulatie: 500-5000 ind.

Geschatte populatie Golf: -

Pioniersoort van voedselarme, vochtige, zwak zure en vaak zandige milieus. Net als borstelbies is het een kensoort van het Dwergbiezenverbond. In Vlaanderen is het een bijzonder zeldzame soort. Aan de kust recent enkel bekend van de Westhoek en de Oosthoekduinen. In 2003 vond Arnout Zwaenepoel tientallen exemplaren van de soort in een sterk betreden, vochtig stuk duin ten noorden van de golf, oostwaarts van de voetgangersbrug (WVI 2004). Vermoedelijk is dwergbloem hier uit een oude zaadvoorraad in de bodem afkomstig. Historisch is de soort ook bekend van het ontkalkte oude duingebied D'Heye. 


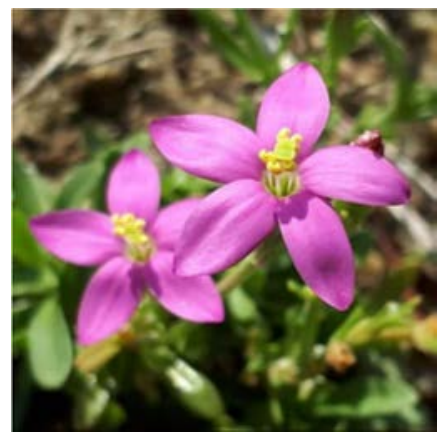

\title{
Strandduizendguldenkruid Centaurium littorale
}

\author{
RL: Zeldzaam
}

Geschatte kustpopulatie: 5000-50 000 ind.

Geschatte populatie Golf: 25-50 ind.

Pionier van vochtige, zoete tot brakke duinvalleien en groene stranden. In Vlaanderen is het een nagenoeg exclusieve kustsoort met uitzondering van een aantal groeiplaatsen op de opgespoten terreinen van de Antwerpse en Zeebrugse haven. Strandduizendguldenkruid is te vinden in natte duinvalleien verspreid over de hele kust maar de Westhoek en de Zwinduinen herbergen samen ongeveer driekwart van de populatie. Op de Golf van De Haan dook de soort op na de natuurontwikkelingswerken ten zuiden van hole 4 en ten noorden van hole 17, bijna zeker vanuit de bodemzaadvoorraad.

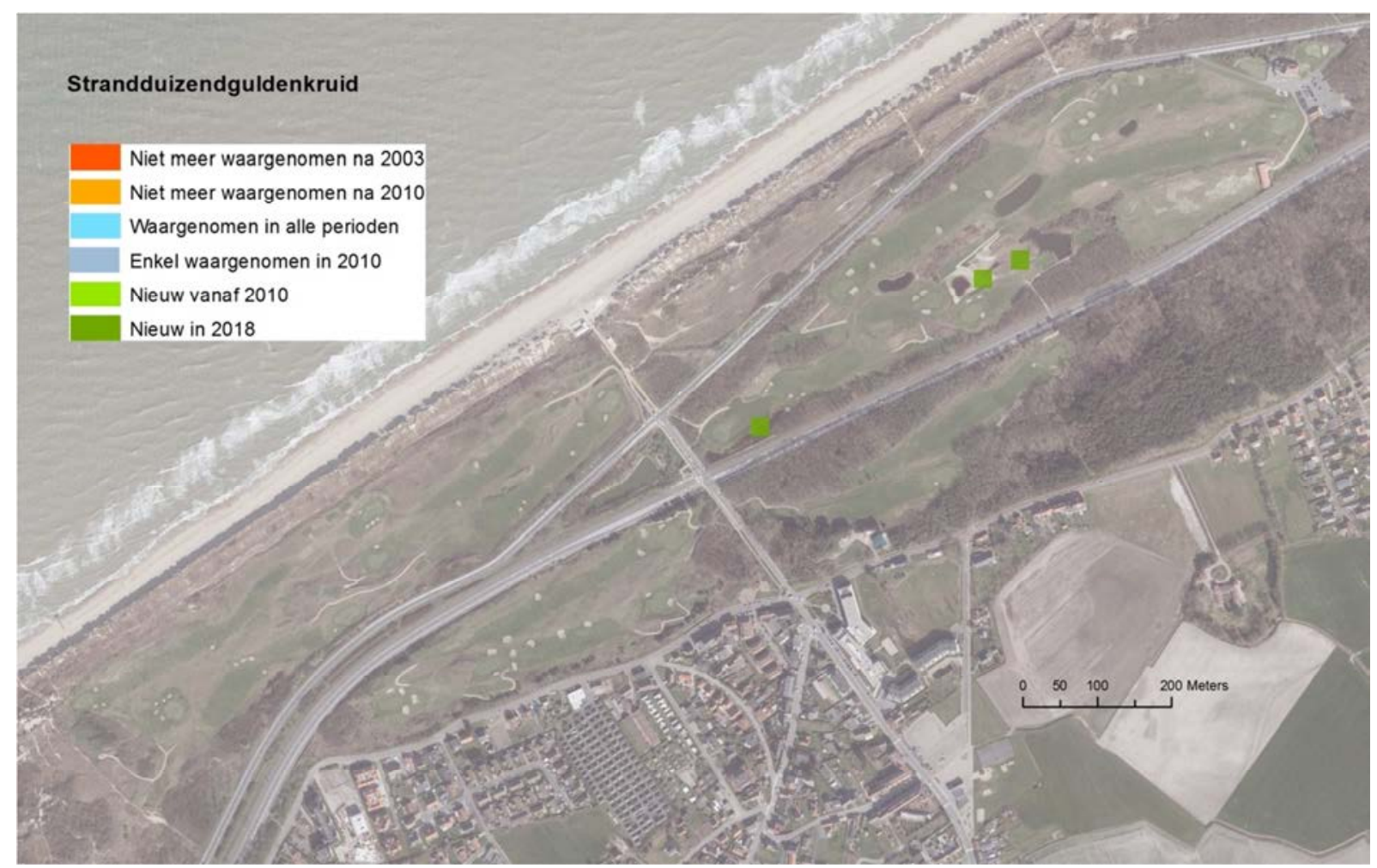




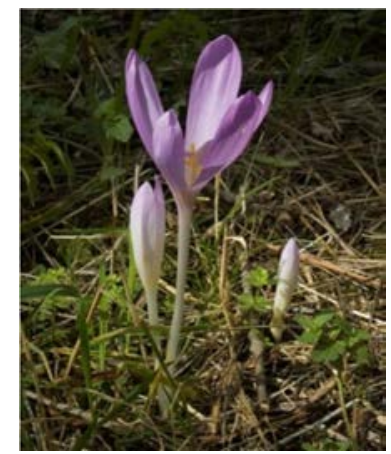

Herfsttijloos Colchicum autumnale

RL: Momenteel niet bedreigd

Geschatte kustpopulatie: 500-5000 ind.

Geschatte populatie Golf: -

Een soort met een vrij brede ecologie gaande van mesotrofe graslanden tot bossen en struwelen op kalkrijke bodem. Ook in de duinen is de soort zowel in graslanden, zomen als bossen te vinden. Toch is het in Vlaanderen een zeldzame soort. Aan de kust is ze vooral van de Westkust bekend. In 2003 vond Arnout Zwaenepoel herfsttijloos ook op de golf (WES 2004) maar de locatie is niet opgenomen in de databank van het INBO. Tijdens de inventarisatie in 2018 werd de soort niet aangetroffen.

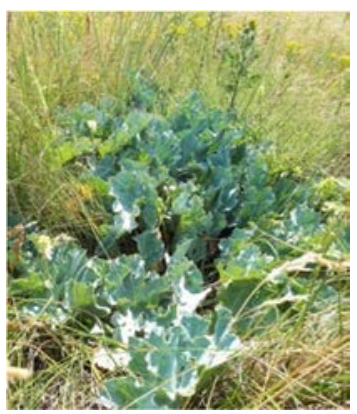

\section{Zeekool Crambe maritima}

\section{RL: Zeldzaam}

Geschatte kustpopulatie: 500-5000 ind.

Geschatte populatie Golf: 2-5 ind.

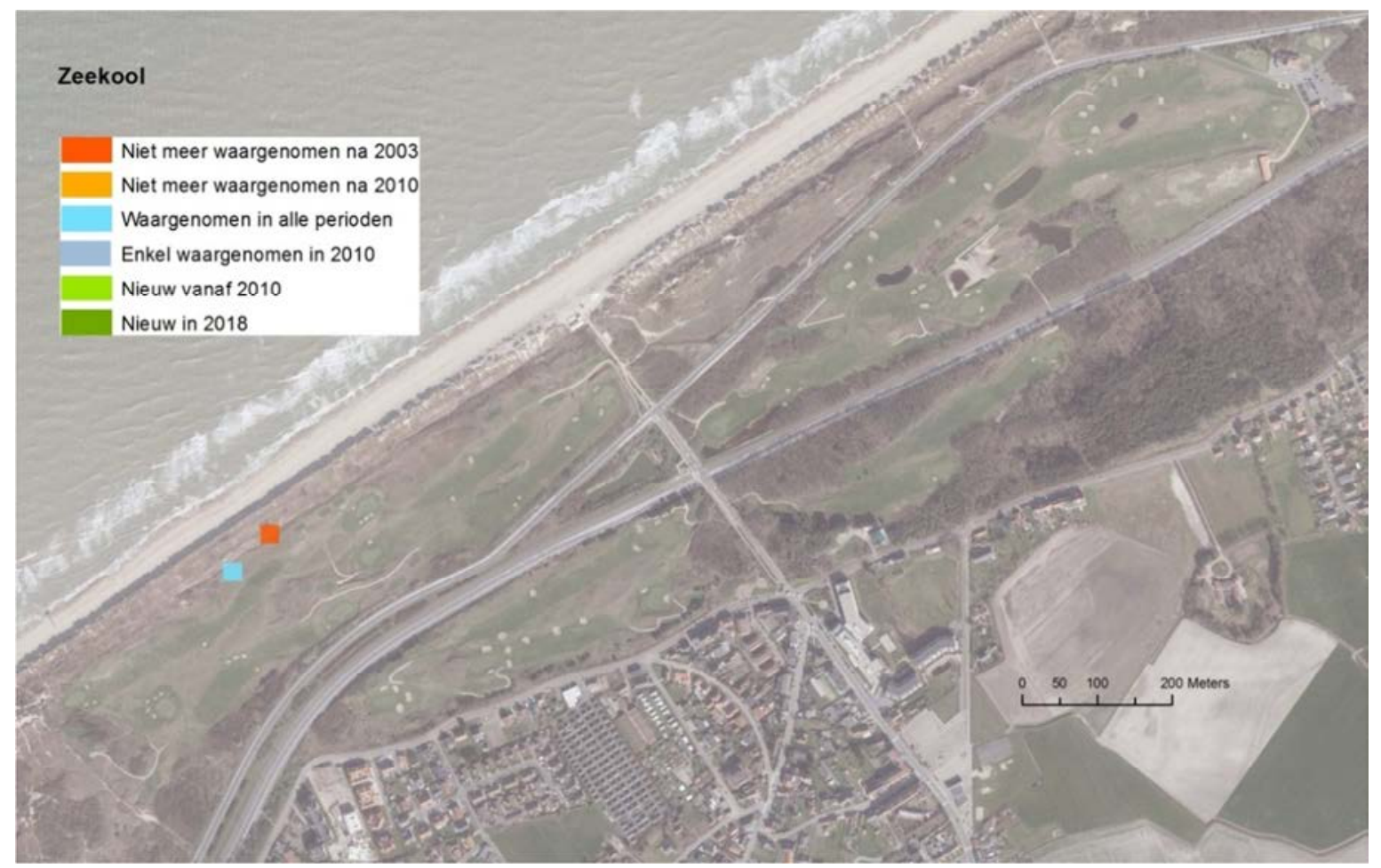


Een soort van keienstranden (shingle beaches), kustkliffen, embryonale duinen en helmduinen in de zeereep. In Vlaanderen wordt de soort vooral in dat laatste milieu aangetroffen maar ook sporadisch op kunstmatige substraten. De eerste vermelding voor Vlaanderen dateert van 1974 (Rappé \& Goetghebeur 1975) sindsdien wordt een geringe uitbreiding vastgesteld. De groeiplaats in de zeereep ten noorden van hole 7 houdt al minstens 15 jaar stand. Een aantal exemplaren groeien ook in de roughs op de golf.

\section{Vleeskleurige orchis Dactylorhiza incarnata}

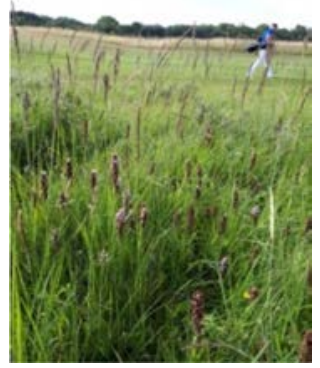

\section{RL: Zeldzaam}

Geschatte kustpopulatie: > 50000 ind.

Geschatte populatie Golf: 50-500 ind.

Een soort van kalkrijke of mineraalrijke maar voedselarme vochtige bodems. In Vlaanderen is het een zeldzame soort met groeiplaatsen verspreid over de hele regio. Vleeskleurige orchis is de meest algemene Dactylorhiza in duinvalleien. Het leeuwendeel van de kustpopulatie bevindt zich in de Westhoek (ca. 95\%). Daarnaast komt de soort ook veelvuldig voor in de duinvalleien van ter Yde. In de overige gebieden is vleeskleurige orchis een zeldzame verschijning. Vleeskleurige orchis is historisch bekend van de golf maar werd tijdens de inventarisatie van 2003 niet waargenomen. Verboven (1980) beschreef de soort als vrij abundant in twee pannetjes; de depressie aan hole 1, waar de soort ook weer werd gevonden in 2010 en aan de vijverrand aan hole 2. De groeiplaats aan hole 1 was in 2018 flink uitgebreid. Daarenboven werden nieuwe groeiplaatsen gevonden in de herstelde duinvallei ten oosten van de green van hole 1 en aan hole 17.

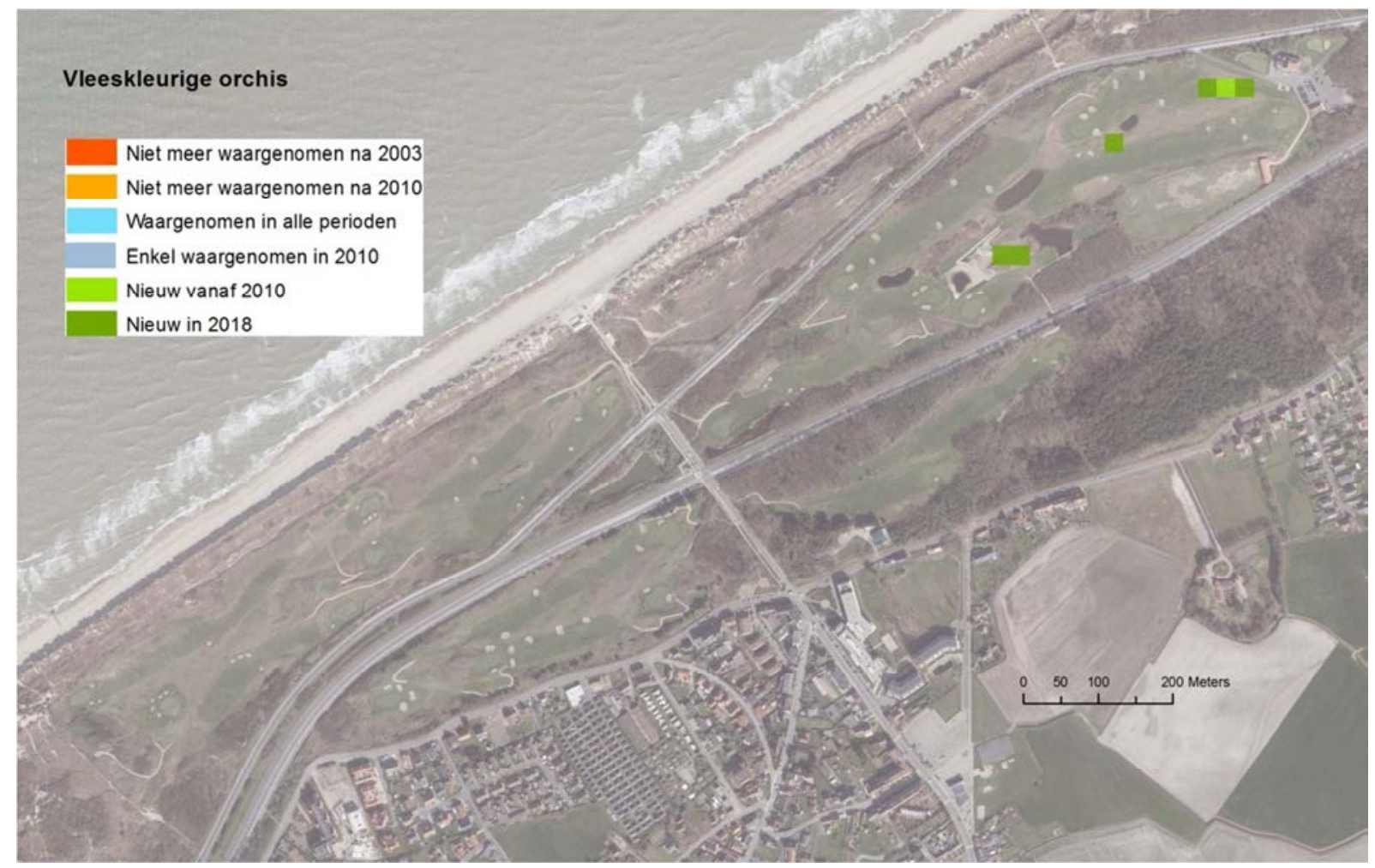




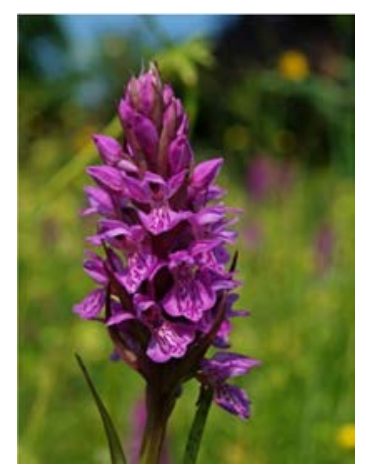

Rietorchis Dactylorhiza praetermissa

RL: Zeldzaam

Geschatte kustpopulatie: 5000-50 000 ind.

Geschatte populatie Golf: 2-5 ind.

Een soort van vochtige tot natte schrale graslanden maar met een voorkeur voor kalkhoudende bodems. In Vlaanderen is de soort globaal zeldzamer dan brede orchis en aan de kust is ze relatief goed vertegenwoordigd. De belangrijkste populaties zijn te vinden in de Fonteintjes, de Warandeduinen en Ter Yde. De soort werd vermeld voor de golf door Verboven (1980) maar is niet waargenomen tijdens de inventarisaties in 2003 en 2010. In 2018 werden opnieuw enkele exemplaren van rietorchis gevonden in de herstelde duinvallei aan hole 17.

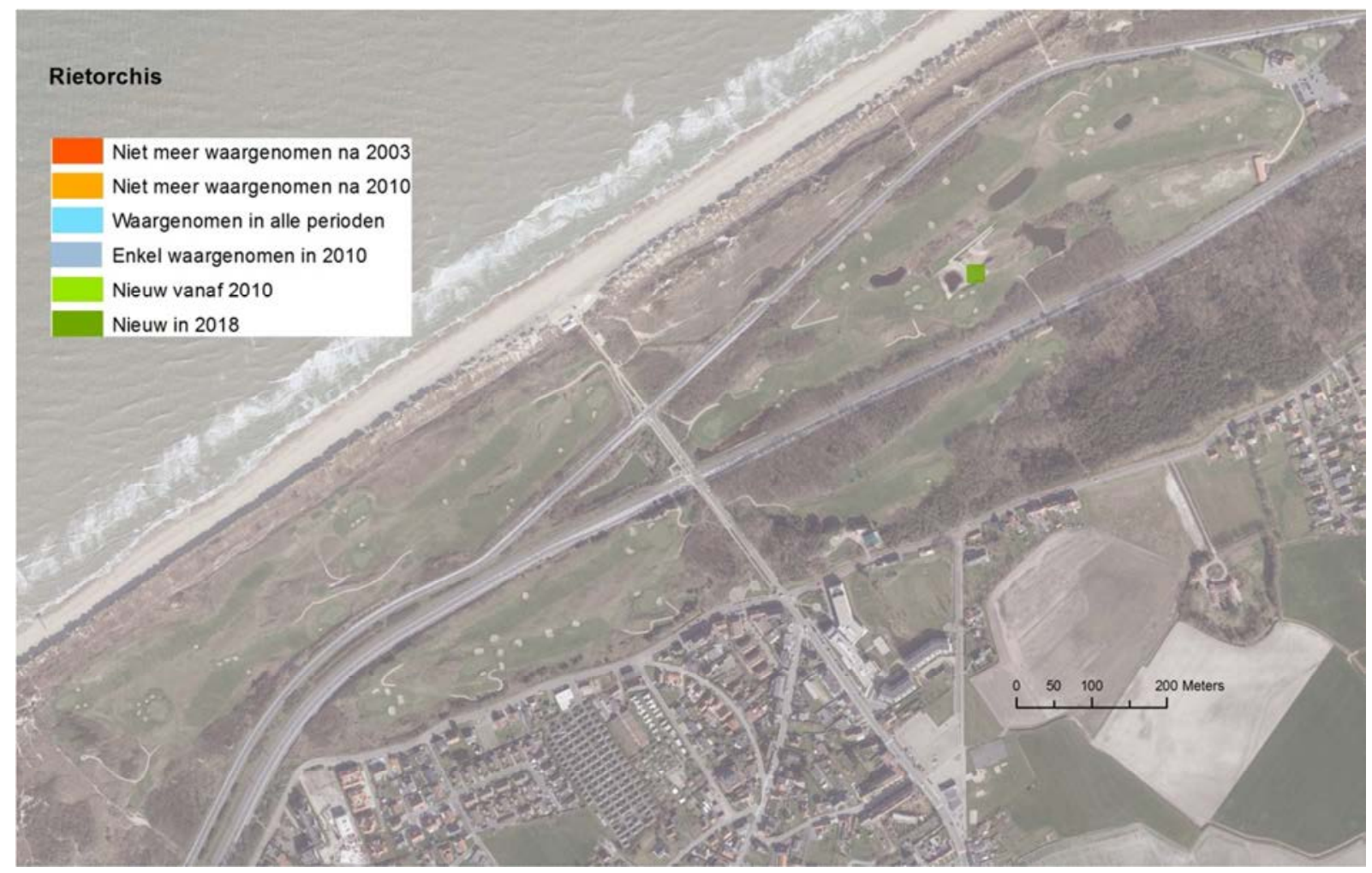




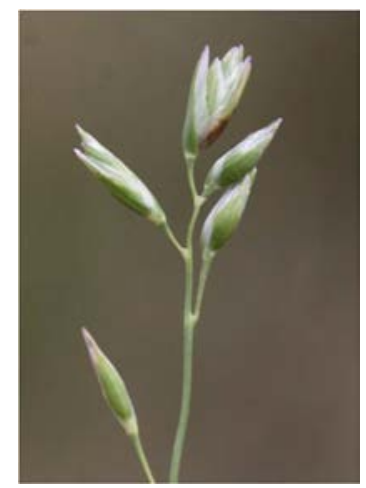

Tandjesgras Danthonia decumbens

RL: Achteruitgaand

Geschatte kustpopulatie: 5000-50 000 ind.

Geschatte populatie Golf: $50-500$ ind.

Een soort met een ecologisch optimum in heischrale graslanden. In Vlaanderen is de soort dan ook vooral in de Kempen en de Brugse zandstreek te vinden. Ook aan de kust vertoont tandjesgras een voorkeur voor de diep ontkalkte oudere duingebieden zoals D'Heye in Bredene-De Haan en Cabour in Adinkerke. Op de golf groeit tandjesgras in het grasland tussen holes 1 en 18 . Verboven (1980) vermeldt de soort als abundant langsheen 2 pannetjes in het noordoostelijk deelgebied. In de kartering van 2003 is de soort wel waargenomen maar niet gekarteerd.

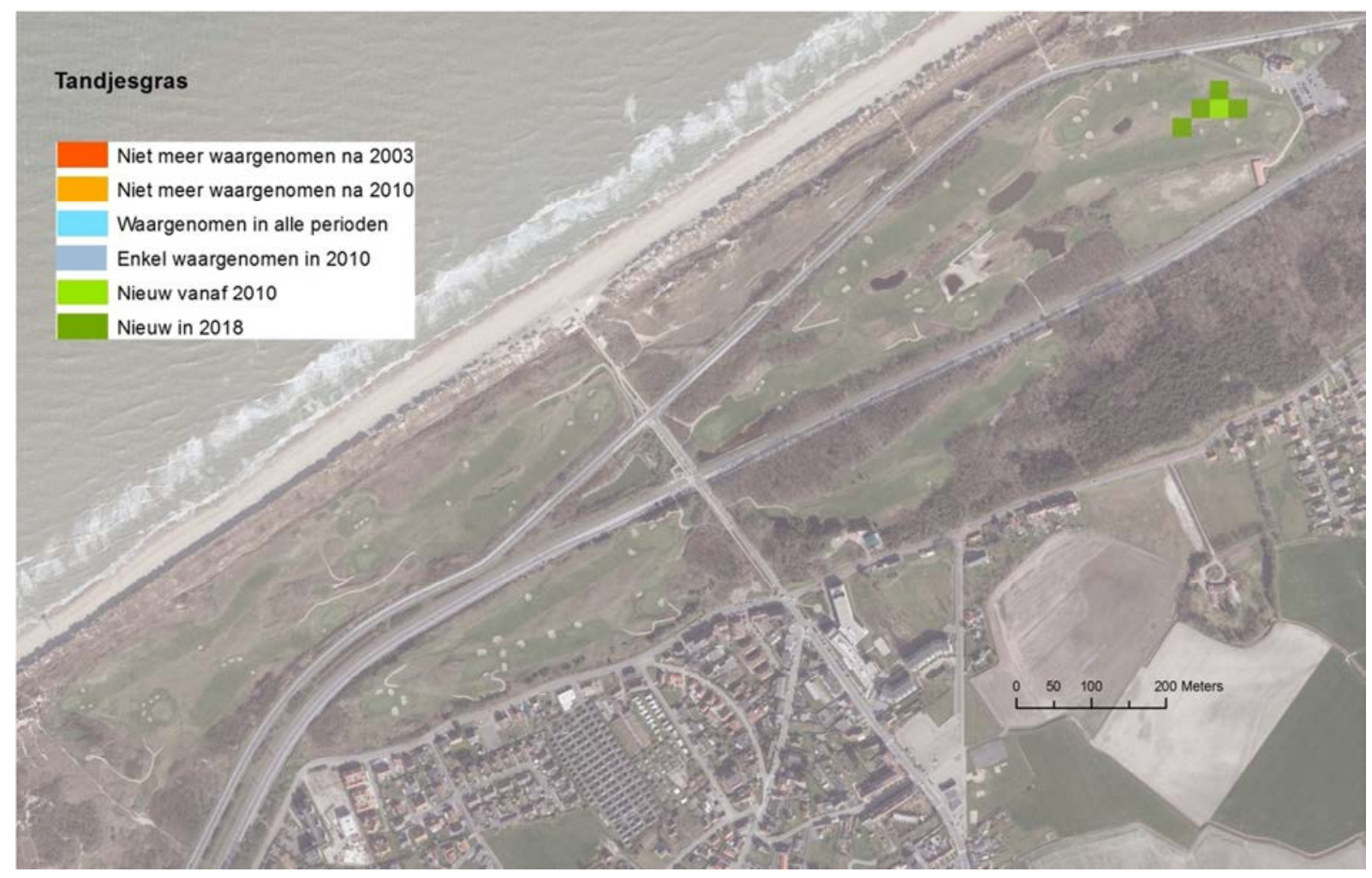




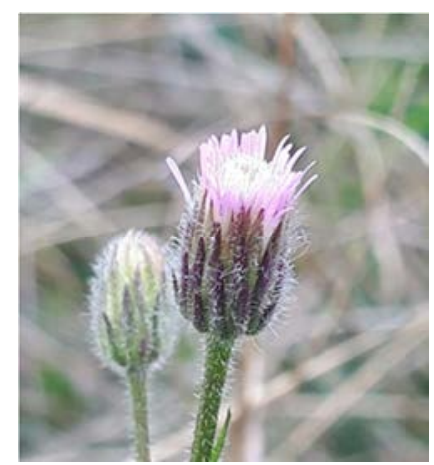

\section{Scherpe fijnstraal Erigeron acer}

\section{RL: Kwetsbaar}

Geschatte kustpopulatie: 5000-50 000 ind.

Geschatte populatie Golf: 25-50 ind.

Een soort van droge tot vochtige graslanden en pioniersituaties. Scherpe fijnstraal is goed vertegenwoordigd aan de kust, elders in Vlaanderen is zij doorgaans zeer zeldzaam. Nagenoeg de helft van de kustpopulatie is te vinden in de Baai van Heist en op de Sashul, verder herbergt ook de Westhoek een groot aantal individuen. Gefixeerd helmduin lijkt een optimale standplaats maar de soort gedijt ook in mosduinen (op noordkantjes bijvoorbeeld), open kruipwilgstruweel en (jong) duingrasland. Op de golf heeft scherpe fijnstraal verschillende groeiplaatsen, geconcentreerd tussen holes 9 en 10.

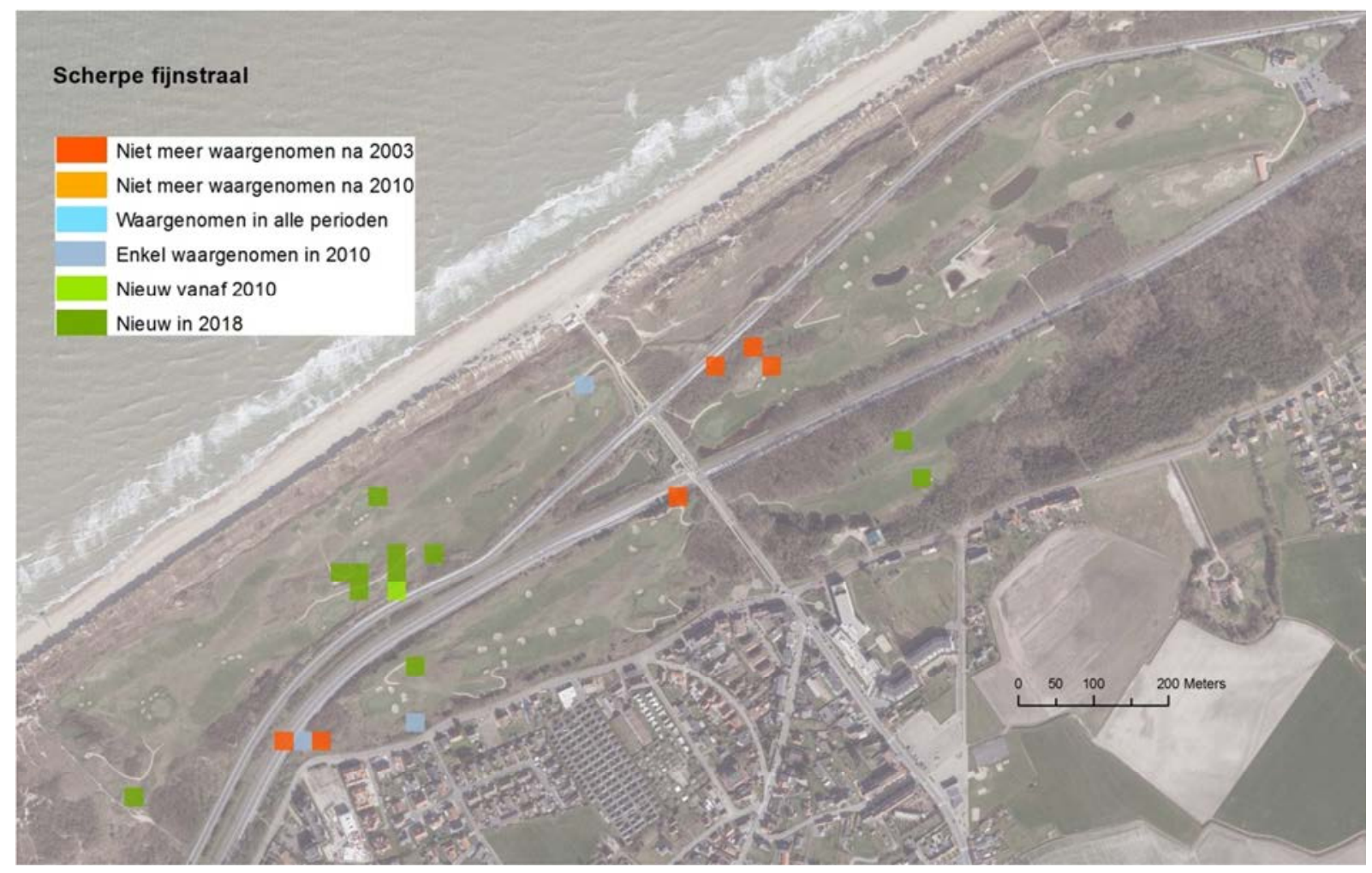




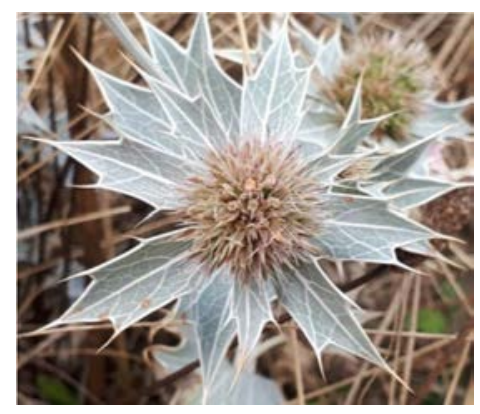

\section{Blauwe zeedistel Eryngium maritimum}

\section{RL: Zeldzaam}

Geschatte kustpopulatie: 5000-50 000 ind.

Geschatte populatie Golf: 5-25 ind.

Een soort van embryonale duinen en helmduinen in de zeereep, soms ook op artificiële substraten in de nabijheid van de zee. In Vlaanderen is blauwe zeedistel strikt kustgebonden en ook aan de kust bevinden de groeiplaatsen zich uitzonderlijk meer dan een paar honderd meter van de hoogwaterlijn. De soort wordt verspreid langs de hele kust gevonden maar de duinen van Middelkerke en het Schipgat herbergen samen ca. $70 \%$ van de populatie. Ook net ten noorden van de golf kan blauwe zeedistel vrij frequent worden aangetroffen en een aantal exemplaren groeit tot in de (jonge) graslanden op de golf. Deze groeiplaatsen waren al bekend door W. Verboven in 1980.

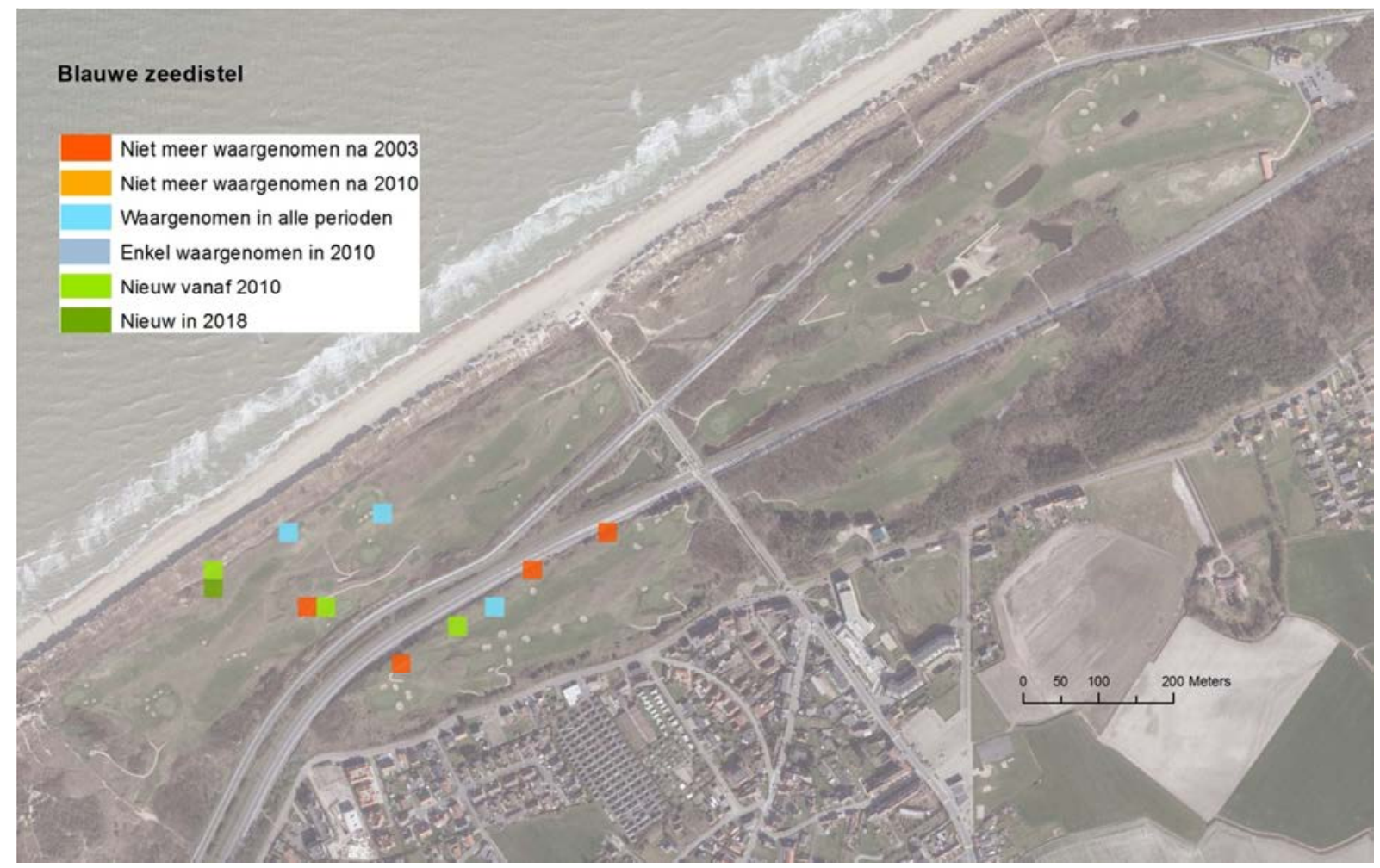




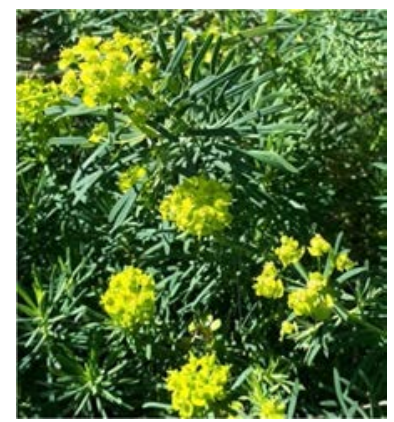

\section{Cipreswolfsmelk Euphorbia cyparissias}

RL: Momenteel niet bedreigd

Geschatte kustpopulatie: 500-5000 m²

Geschatte populatie Golf: $500-5000 \mathrm{~m}^{2}$

Een soort van droge graslanden op gebufferde (veelal kalkrijke) bodem die in Vlaanderen vooral in kunstmatige milieus wordt gevonden. In Nederland behoort cipreswolfsmelk tot de typische flora van stroomdalgraslanden, samen met onder meer echte kruisdistel, wilde marjolein en sikkelklaver. Aan onze de kust is de soort bekend van Ter Yde en de duinen van De Haan. Op de golf van de Haan wordt het grootste deel van de kustpopulatie aangetroffen. Ze vertoont de voorbije 15 jaar een sterke uitbreiding in het westen van het gebied.

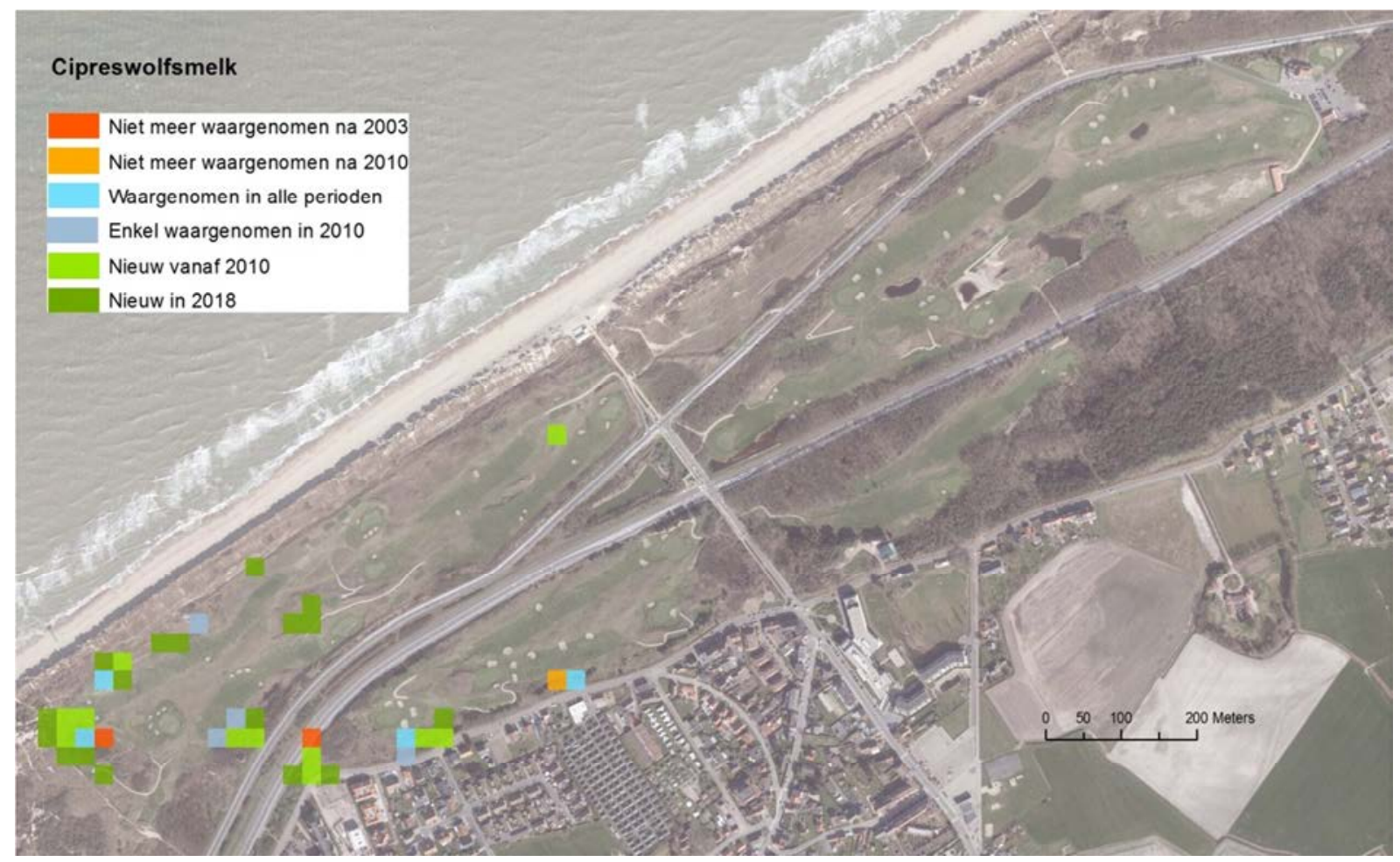




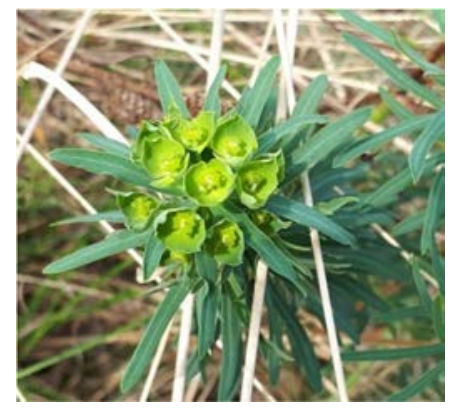

Heksensmelk Euphorbia esula

RL: Momenteel niet bedreigd

Geschatte kustpopulatie: 50-500 ind.

Geschatte populatie Golf: 5-25 ind.

Een soort van, relatief vochtige en voedselrijke zandbodems die in België vooral in de Maasvallei wordt aangetroffen. Aan de kust bekend van één groeiplaats in de wegberm langs de Koninklijke Baan aan en net in de golf van De Haan. Deze kleine populatie lijkt er de voorbije 15 jaar relatief stabiel te zijn.

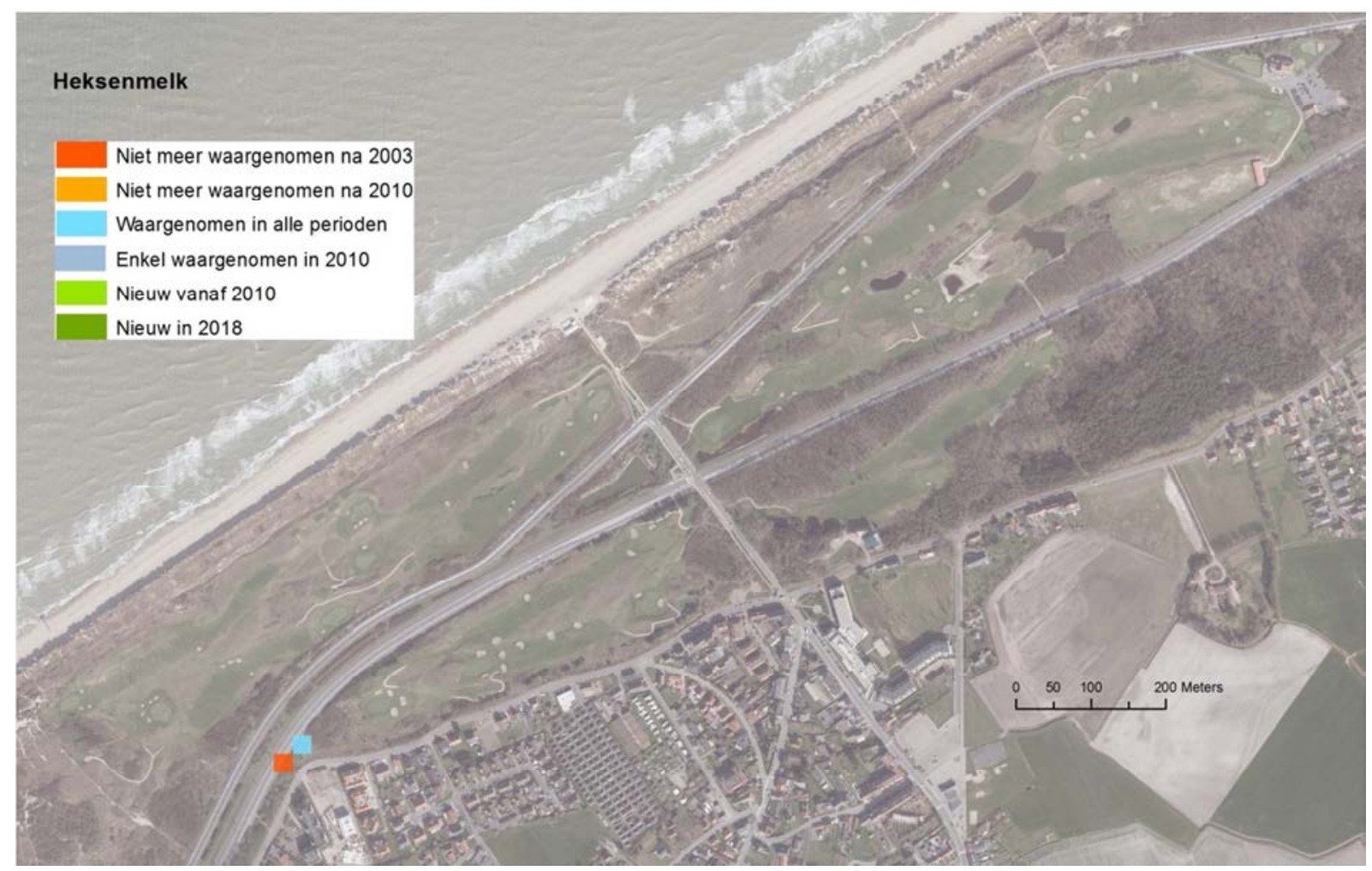




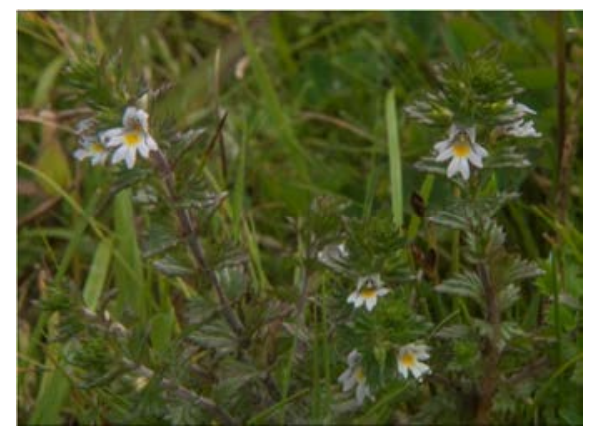

Ogentroost Euphrasia

RL: Kwetsbaar

Geschatte kustpopulatie: >50 000 ind.

Geschatte populatie Golf: -

Gezien de taxonomische verwarring tussen de verschillende soorten wordt de verspreiding van ogentroost op het niveau van geslacht behandeld. De vertegenwoordigers van dit geslacht zijn halfparasieten die groeien in schrale graslanden. Zij parasiteren op wortels van grassen en cypergrassen. Aan de kust vinden we ogentroost vooral in en in mindere mate ook in de droge graslanden. Ruim $80 \%$ van de individuen wordt aangetroffen in de Westhoek en Ter Yde. Verboven trof de soort aan in 3 opnames in verschillende terreindelen van de golf. In de karteringen van 2003 en later is de soort echter niet meer teruggevonden.

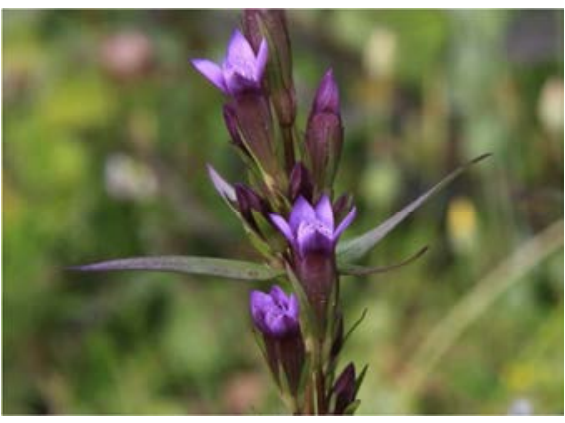

Duingentiaan Gentianella uliginosa

RL: Met verdwijning bedreigd

Geschatte kustpopulatie: 500-50 000 ind.

Geschatte populatie Golf: -

Een soort van vochtige tot natte rijpe duinvalleien en graslanden. Duingentiaan heeft een beperkt Europees verspreidingsgebied dat zich vooral in het noorden van Duitsland en Polen bevindt. Verder zijn er verschillende groeiplaatsen bekend langs de kust tussen Noord-Frankrijk en ZuidScandinavië en wordt de soort nog op een aantal geïsoleerde voorposten gevonden. In België is duingentiaan beperkt tot de duinen. Historische groeiplaatsen zijn bekend van verschillende duingebieden verspreid over de hele kustlijn, maar de soort kende een sterke achteruitgang in de 20ste eeuw. De soort wordt vermeld voor de golf door De Raeve et al. (1983). Deze auteurs vonden de soort in de jaren '80 op de oever van een duinplasje maar daarna werd ze in het gebied niet meer teruggevonden. Recent kent duingentiaan een behoorlijk spectaculaire remonte door natuurontwikkelingsmaatregelen in verschillende duingebieden. De verspreiding wordt in de hand gewerkt doordat zaden aan maaimachines blijven kleven. 
Geel zonneroosje Helianthemum nummularium

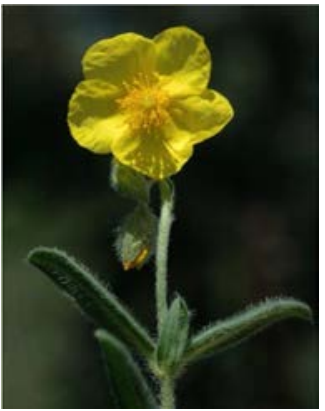

RL: Zeldzaam

Geschatte kustpopulatie: > $500000 \mathrm{~m}^{2}$

Geschatte populatie Golf: 5-25 m²

Een soort van droge tot vochtige kalkrijke graslanden die in Vlaanderen enkel bekend is van de kustduinen en de Sint Pietersberg. In duingraslanden doet de soort het goed onder begrazing. Passage door het spijsverteringsstelsel van grote grazers blijkt de kiemkracht van de zaden te bevorderen (Milotic et al. 2017). De Doornpanne en Ter Yde herbergen samen ca. 80\% van de kustpopulatie. Op de golf werd de soort nog op 3 relatief beperkte groeiplaatsen teruggevonden, allemaal in het noordoostelijk deelgebied. De gelimiteerde populatie in combinatie met de zeer beperkte verbreiding in de afwezigheid van grote grazers maakt de soort kwetsbaar.

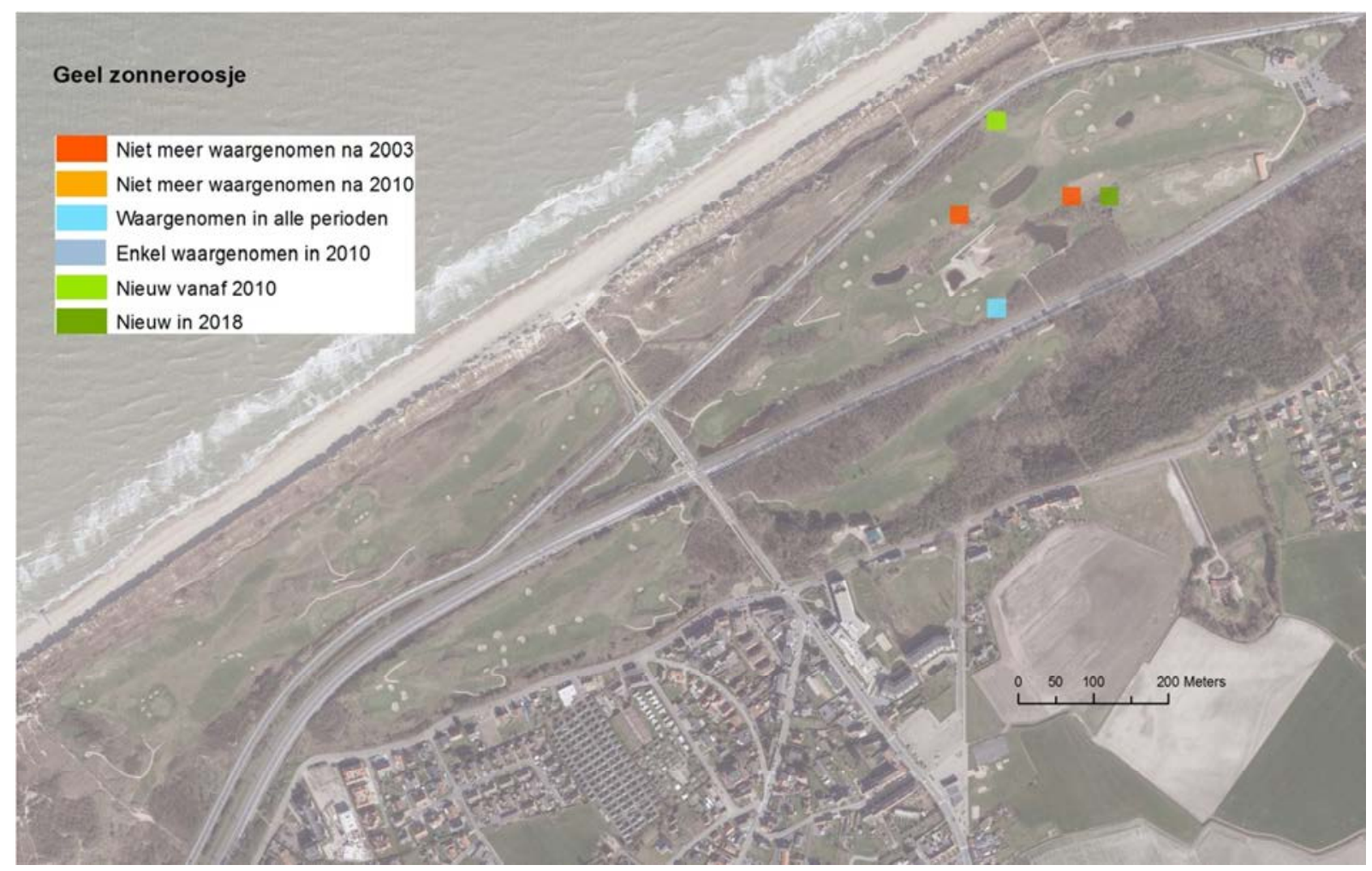




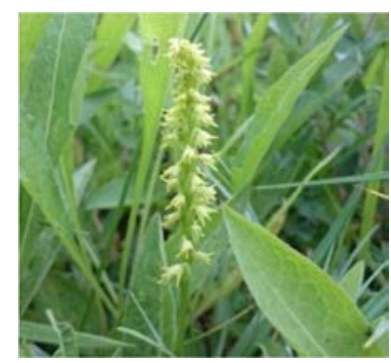

\section{Honingorchis Herminium monorchis}

RL: Met verdwijning bedreigd

Geschatte kustpopulatie: 500-5000 ind.

Geschatte populatie Golf: -

Een delicate soort van voedselarme en kalkrijke graslanden en moerassen (zoals duinvalleien). In België is de soort momenteel beperkt tot de kustduinen maar bijvoorbeeld in Noord-Frankrijk wordt de soort ook in het binnenland gevonden. Onze regio maakt geen deel uit van het hoofdareaal van de soort. Honingorchis kende aan onze kust een sterke achteruitgang in de tweede helft van de $20^{\text {ste }}$ eeuw. Terwijl de soort historisch verspreid over de hele kust kon worden gevonden, was er in de jaren '90 nog slechts één beperkte groeiplaats bekend. Dankzij het natuurherstel breidt de soort zich geleidelijk aan uit en momenteel is de soort weer aanwezig in verschillende gebieden aan de westkust. Honingorchis is historisch ook bekend van het golfterrein en wordt nog vermeld door lokale natuurkenners die er al langer actief zijn (WVi 2004). Gezien de soort net als andere orchideeën stoffijn zaad produceert en gemakkelijk door de wind wordt verbreid, is hervestiging niet onmogelijk maar door de geringe oppervlakte aan geschikte habitat is de kans voorlopig klein. 


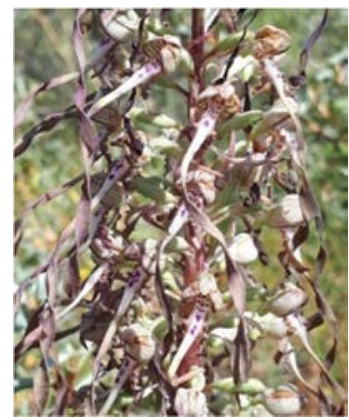

Bokkenorchis Himantoglossum hircinum

\author{
RL: Bedreigd
}

Geschatte kustpopulatie: 500-5000 ind.

Geschatte populatie Golf: 500-5000 ind.

Een soort van kalkrijke graslanden die in onze regio de noordgrens van haar areaal bereikt(e). In Vlaanderen is de bokkenorchis nagenoeg beperkt tot de duinen waar de soort in doorgaans iets verruigde graslanden en gefixeerde helmduinen wordt gevonden. Ca. 90\% van de (Vlaamse) populatie is te vinden op en in de onmiddellijke nabijheid van de golf van De Haan. Het is onduidelijk hoe die populatie zich daar heeft gevestigd. Mogelijk heeft ze zich gevestigd in het interbellum, een eerste klimatologische opstootperiode (De Langhe 1944; Leten 1989). Tot een vijftiental jaar geleden waren er sporadisch meldingen van bokkenorchis verspreid over de kust maar deze groeiplaatsen bleken snel weer te verdwijnen. De laatste jaren hebben zich weer blijvende populaties gevormd in verschillende duingebieden. Verboven (1980) beschrijft de verspreiding als 'erg abundant in de Heuveltjes' (ZW terreindeel), een paar exemplaren in de 'Bosjes' (ZO deelgebied) en telkens één exemplaar in de 'Jasmientjes' (NO) en het 'Zeetje'(NW). In dit laatste deelgebied vinden we actueel grootste populatie. Het zwaartepunt van de verspreiding is dus sedert de jaren ' 80 zeewaarts verschoven. Het is een trend die zich ook de voorbije 15 jaar lijkt verder te zetten. De populatiegrootte lijkt te fluctueren maar vertoont geen duidelijke trend.

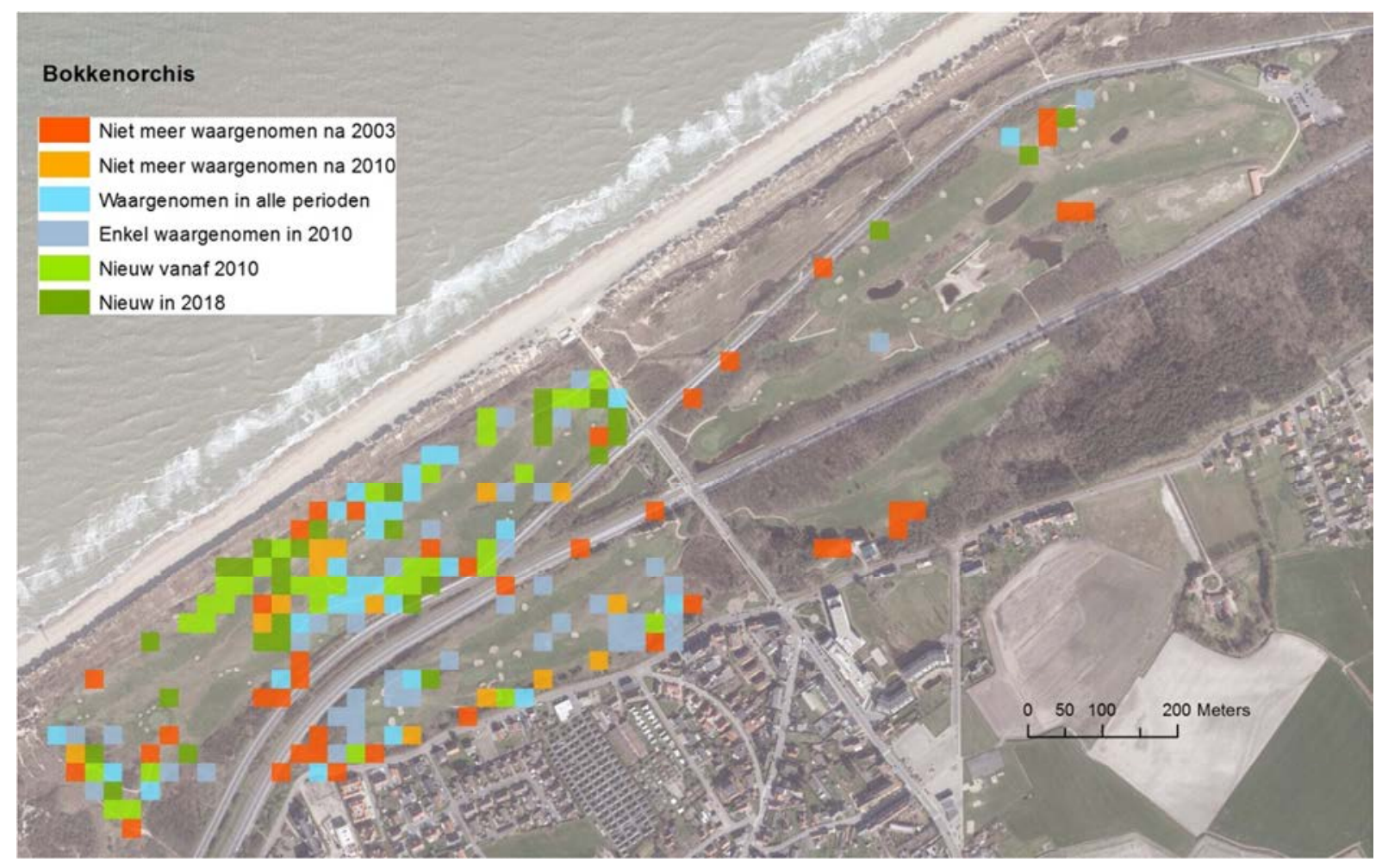




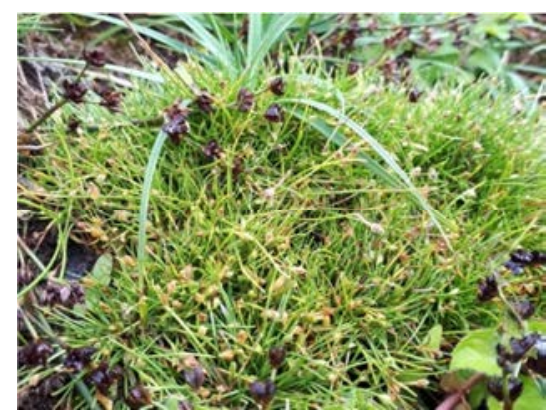

\section{Borstelbies Isolepis setacea}

RL: Momenteel niet bedreigd

Geschatte kustpopulatie: 5000-50 000 ind.

Geschatte populatie Golf: 5-25 ind.

Pioniersoort van vochtige tot natte, relatief voedselarme bodems met uiteenlopende textuur. Het is één van de meer algemene vertegenwoordigers van het dwergbiezenverbond. In de duinen is het een pionier van natte pannen. In Vlaanderen verspreid aanwezig met een zwaartepunt in de zandstreken. Aan de kust is ongeveer $80 \%$ van de individuen te vinden in de Westhoek en D'Heye, en sinds 2009 ook in de Zwinduinen. De soort werd in 2010 waargenomen aan hole 4 en lijkt zich te hebben uitgebreid. In 2018 is borstelbies ook waargenomen in de herstelde duinpannes ten oosten van de green van hole 3 en aan de vochtige zuidrand van hole 2 . Mogelijk is borstelbies tijdens eerdere karteringen over het hoofd gezien want de soort is historisch bekend van het gebied (Van Landuyt et al. 2006).

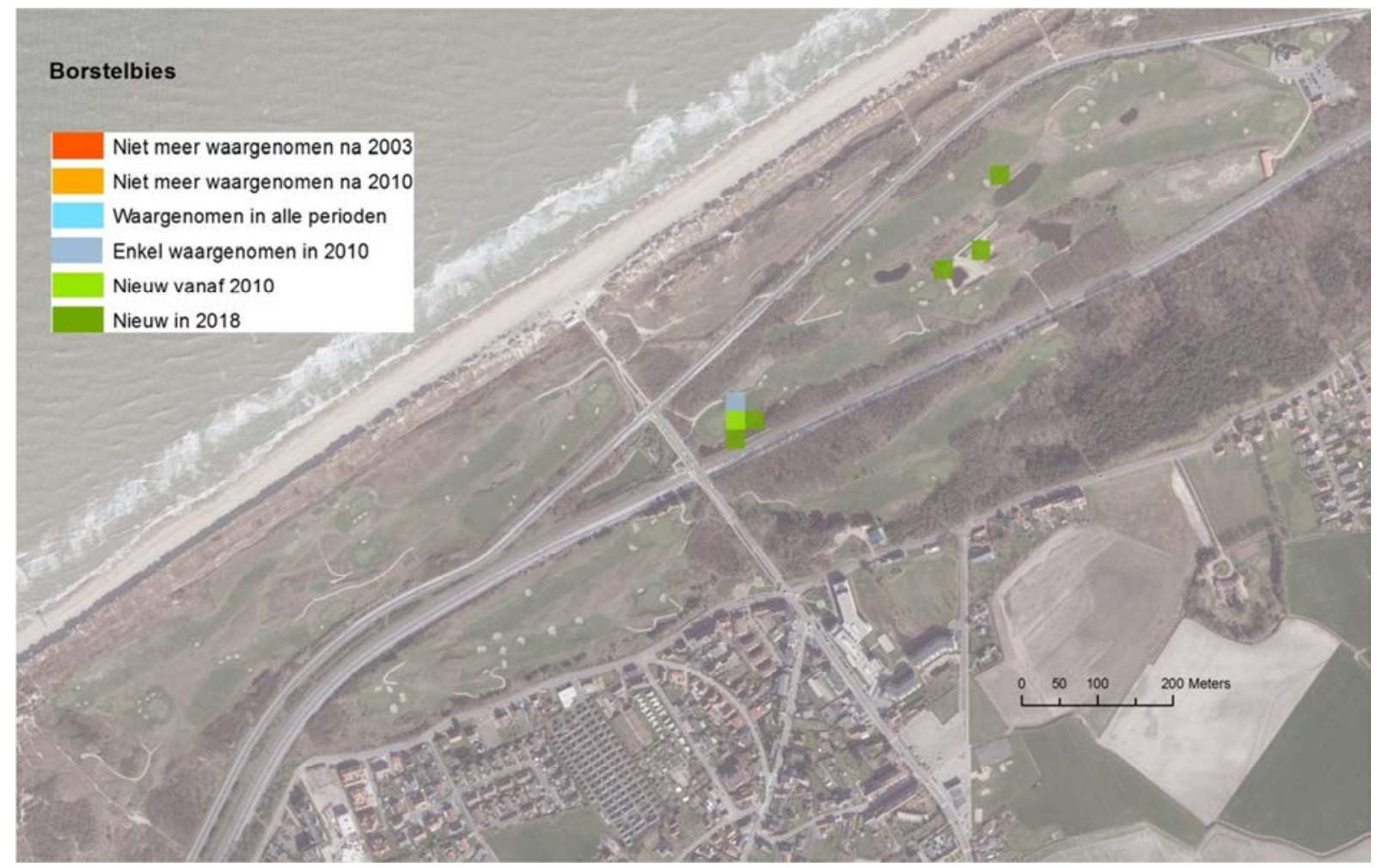




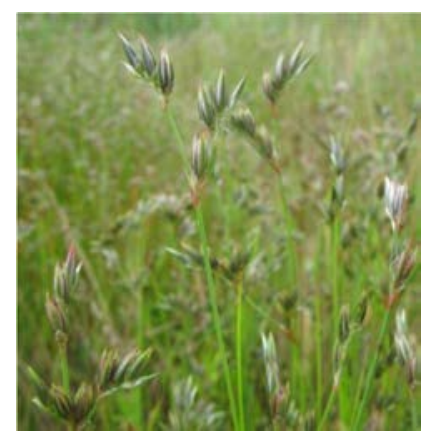

\section{Gestreepte greppelrus Juncus foliosus}

RL: -

Geschatte kustpopulatie: 50-500 ind.

Geschatte populatie Golf: 50-500 ind.

Een pioniersoort op standplaatsen met (sterk) wisselende waterstanden die pas in 1984 in Vlaanderen, meer bepaald in het Midden-Limburgs vijvergebied, werd ontdekt (Vannerom 1984). De verspreiding van de een soort is niet goed gekend maar het oorspronkelijk areaal is vermoedelijk zuidelijk Atlantisch. De soort kan gemakkelijk verward worden met gewone greppelrus. Tijdens de kartering in 2018 werden enkele tientallen individuen op de golf aangetroffen, ter hoogte van holes 3 en 16.

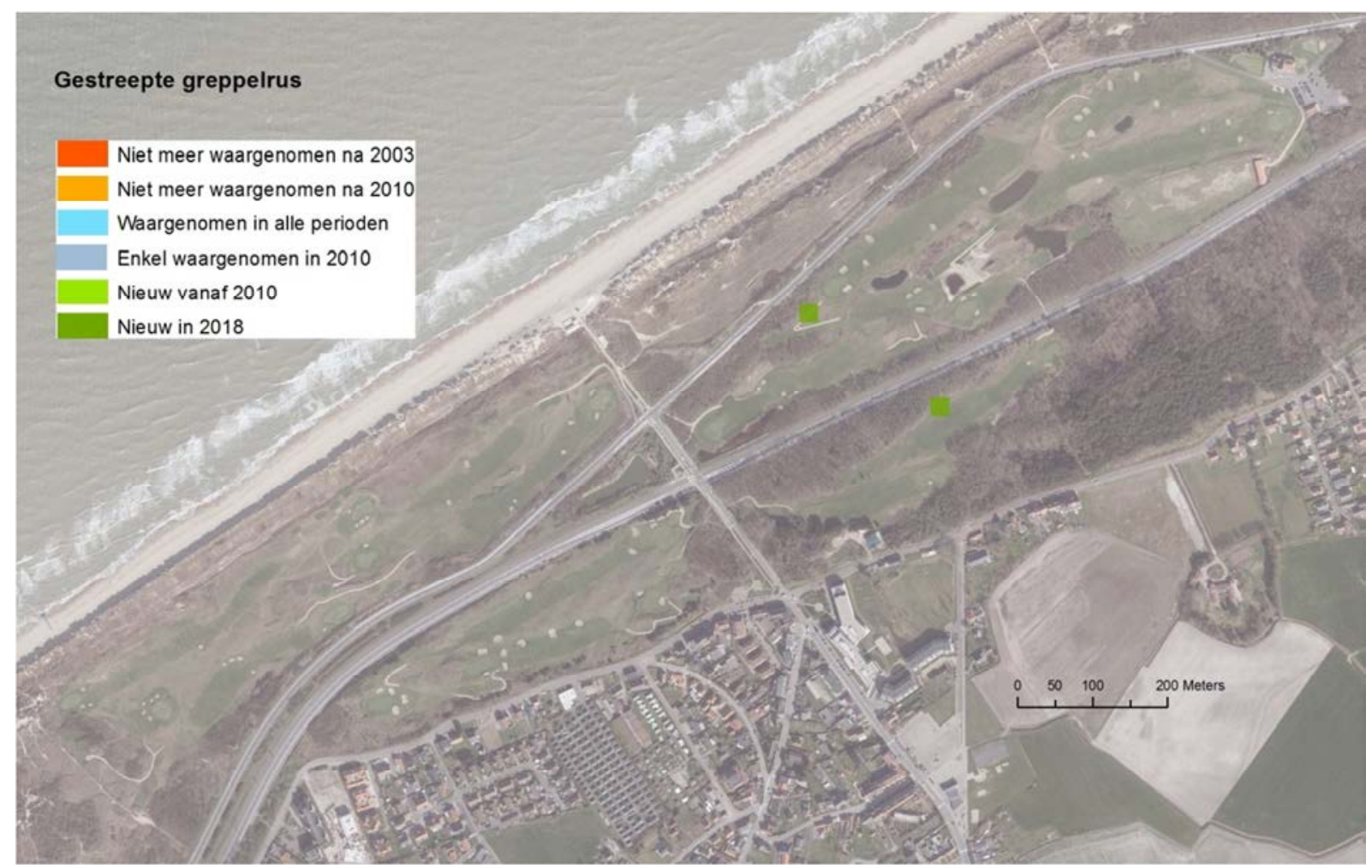




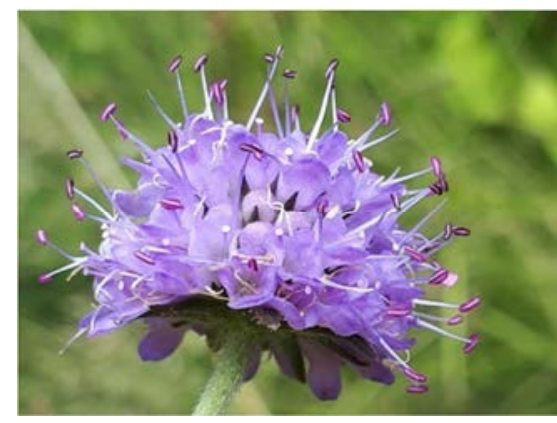

\section{Beemdkroon Knautia arvensis}

\section{RL: Achteruitgaand}

Geschatte kustpopulatie: 50-500 ind.

Geschatte populatie Golf: 5-25 ind.

Een soort van droge graslanden op kalkhoudende bodem zoals kalkrijke glanshavergraslanden. In Vlaanderen globaal relatief zeldzaam maar algemeen in de oostelijke leemstreek en aan de Maas. Aan de kust is het een zeer zeldzame soort die actueel enkel bekend is van de bermen van de Koninklijke Baan in Bredene-De Haan. Volgens de inventarisatiegegevens van Massart (1912) was de soort rond de vorige eeuwwisseling vrij algemeen aan de Westkust, hoewel volgens Marc Leten verwarring met blauwe knoop niet geheel valt uit te sluiten. Anderzijds zou een achteruitgang van beemdkroon wel kunnen samensporen met de achteruitgang van margriet in de duinstreek. Op het golfterrein werd in 2010 een kleine groeiplaats vastgesteld op de helling ten westen van hole 7 die goed lijkt stand te houden.

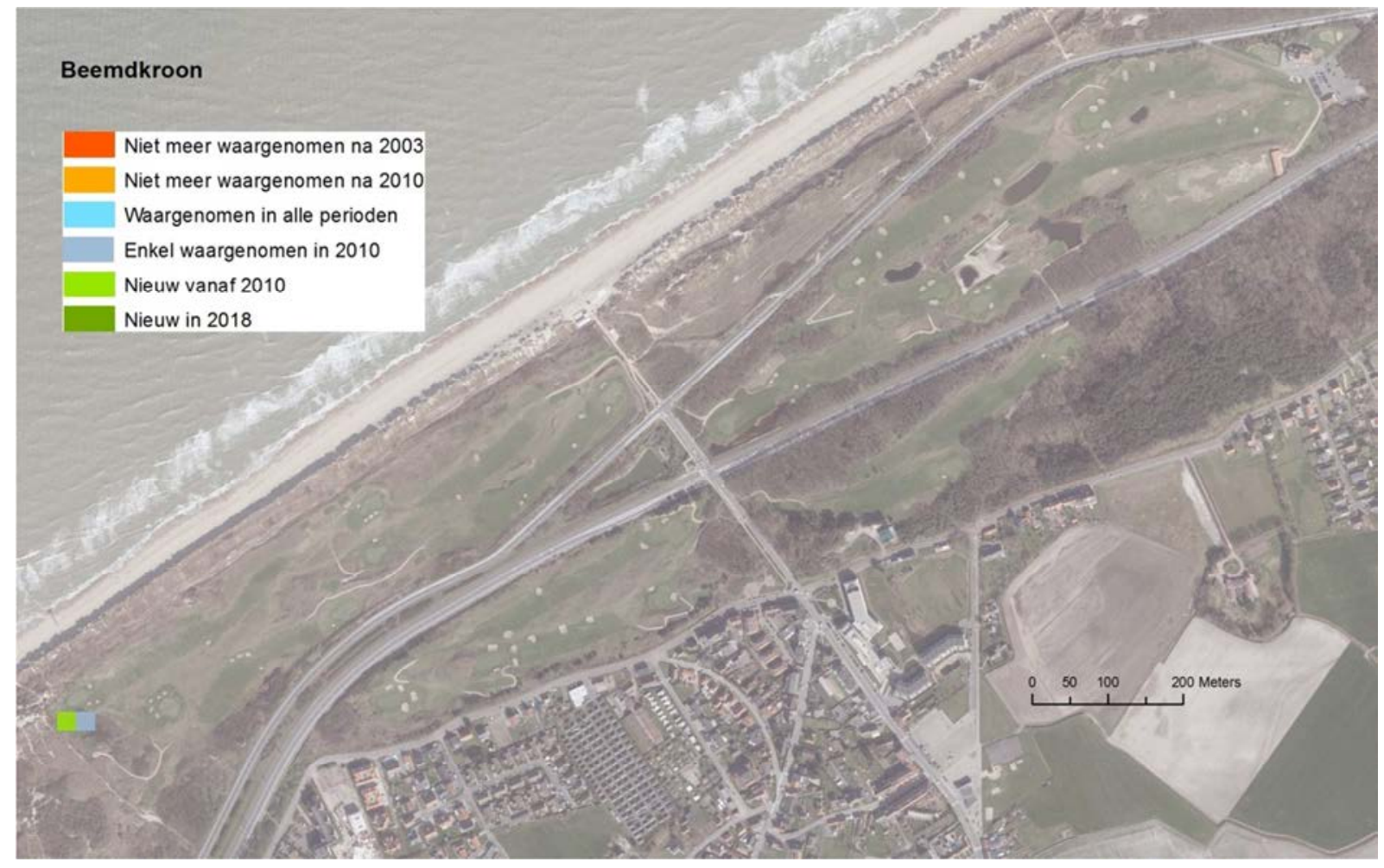




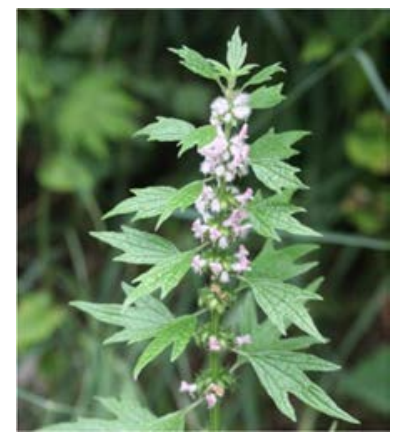

\section{Hartgespan Leonurus cardiaca}

\section{RL: Zeldzaam}

Geschatte kustpopulatie: 50-500 ind.

Geschatte populatie Golf: -

Een soort van nitrofiele ruigten en zomen op basische bodem. In onze streken is hartgespan vermoedelijk door de mens geïntroduceerd omwille van medicinale eigenschappen en als honingplant voor bijen. Ongeveer 90 \% van de kustpopulatie groeit binnen de gemeente De Panne. In 2003 werd hartgespan waargenomen in het open bos ten oosten van de werkplaats. De soort werd er niet meer waargenomen tijdens de meer recente inventarisaties.

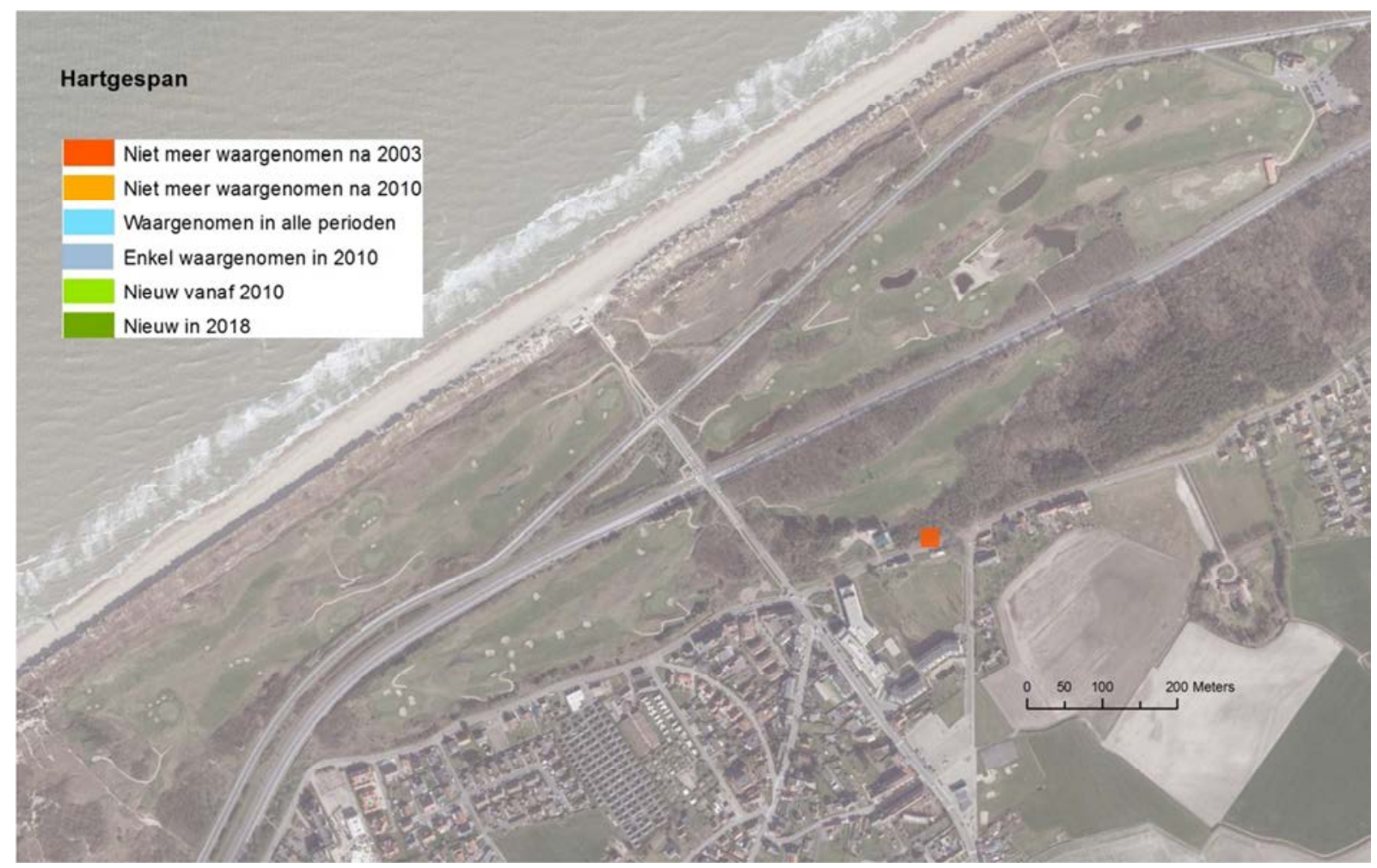




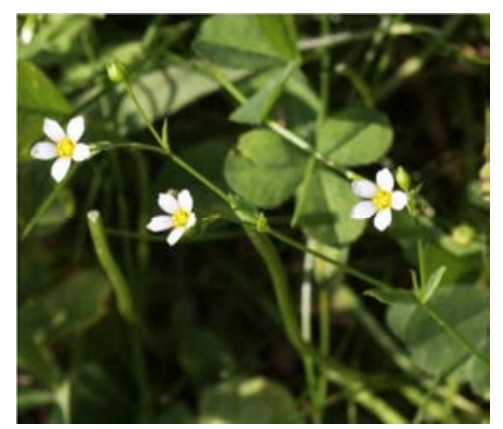

Geelhartje Linum catharticum

RL: Bedreigd

Geschatte kustpopulatie: 50-500 ind.

Geschatte populatie Golf: -

Een soort van diverse typen voedselarm, open grasland. Buiten de kalkgraslanden is de soort grondwaterafhankelijk. Aan de kust is de soort bekend van natte pannen en vochtige duingraslanden. Ongeveer driekwart van de populatie groeit in de Westhoek, een klein vierde kwart in Ter Yde. Verder komt de soort in kleine aantallen voor verspreid over de kust, vermoedelijk in een aantal gevallen door maaimachines verbreid. Verboven (1980) vond de soort in minstens 11 opnames op het golfterrein. Ook tijdens de inventarisaties van 2003 en 2010 werden nog enkele plantjes waargenomen. In 2018 werd de soort echter niet meer teruggevonden.

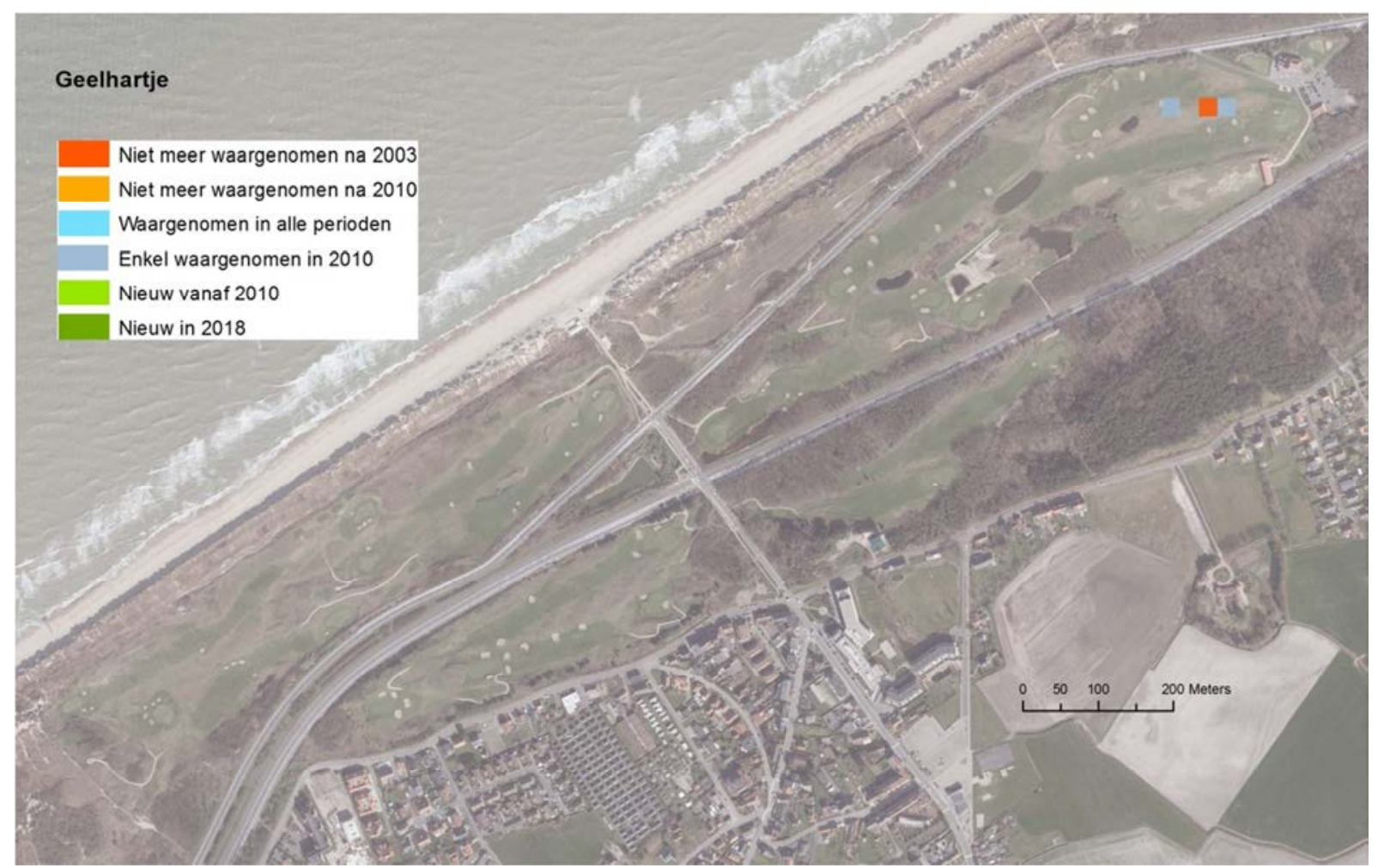




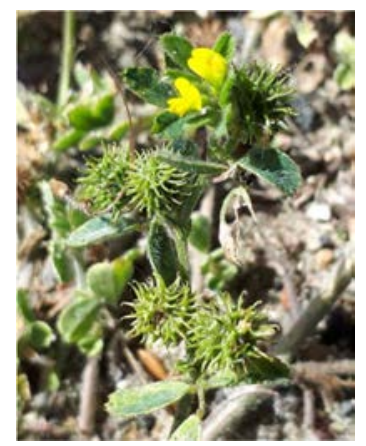

Kleine rupsklaver Medicago minima

RL: Zeldzaam

Geschatte kustpopulatie: 500-5000 ind.

Geschatte populatie Golf: 50-500 ind.

Thermofiele éénjarige van kalkrijke, relatief voedselarme maar bij ons eerder ruderale standplaatsen. Het zwaartepunt van de verspreiding ligt in het Middellands Zeegebied maar de soort wordt noordwaards tot Zuid Zweden waargenomen. Kleine rupsklaver is in Vlaanderen grotendeels beperkt tot de kust en de grensmaas. Aan de kust komt de soort verspreid voor, vooral in open, enigszins ruderale bermen en zelden in de duingebieden zelf. Kleine rupsklaver werd op de golf waargenomen in 2003 en in 2018, niet in de tussenliggende periode. De locaties uit beide perioden liggen bijna anderhalve kilometer uiteen. Mogelijk zijn er dus nog groeiplaatsen van deze kleine eenjarige over het hoofd gezien. De lokale populatie is toegenomen van 1 exemplaar (gekarteerd) in 2003 naar enkele tientallen exemplaren in 2018.

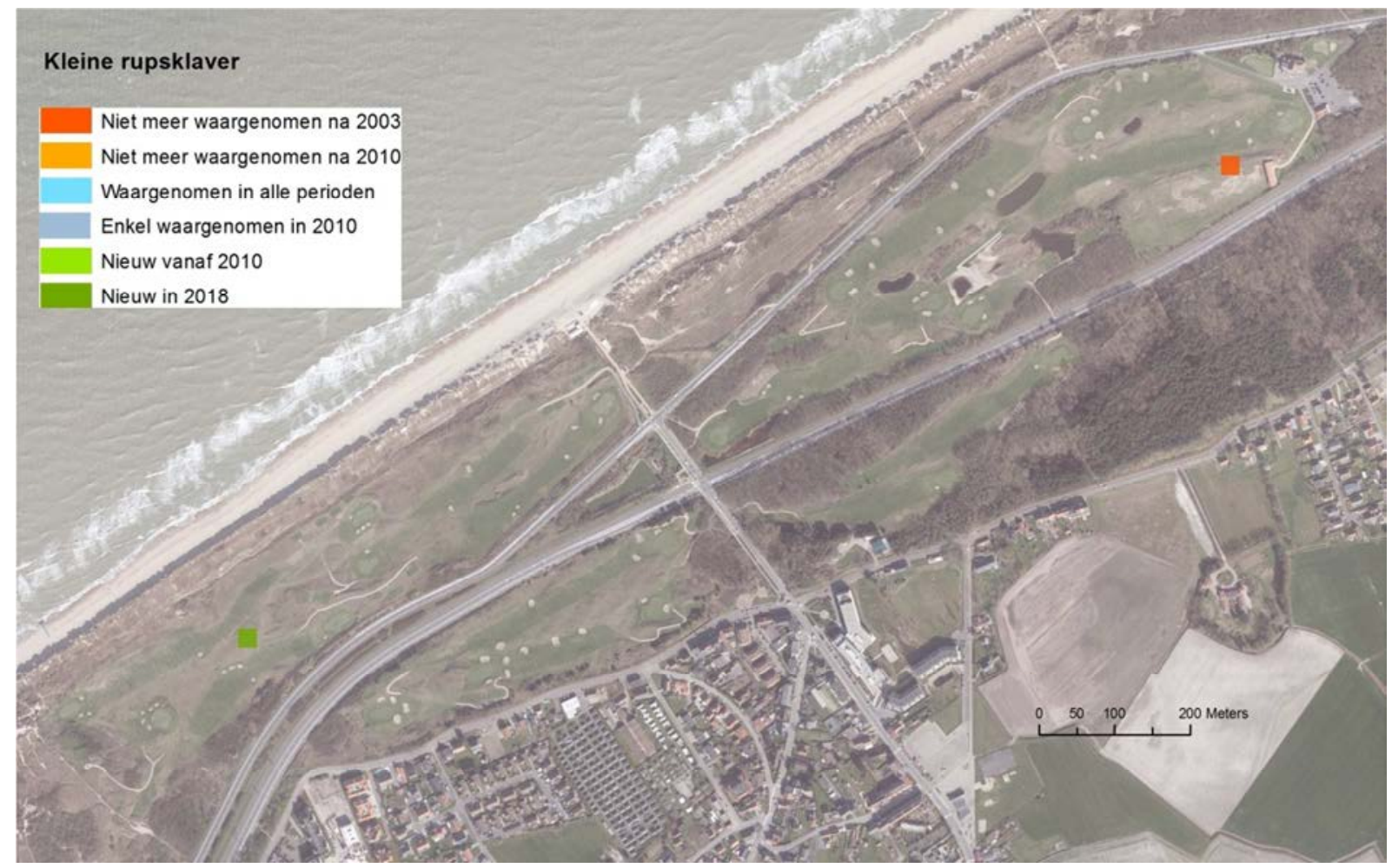




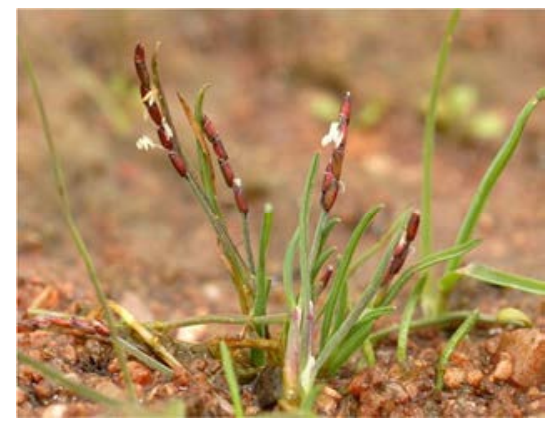

\section{Dwerggras Mibora minima}

\section{RL: Bedreigd}

Geschatte kustpopulatie: 5000-50 000 ind.

Geschatte populatie Golf: -

Klein eenjarig grasje van droge, voedselarme, open en vaak zure zandgrond. Zeer zeldzaam in Vlaanderen en aan de kust enkel bekend van De Panne en De Haan. In de Westhoek is de populatie sterk uitgebreid tot actueel vele duizenden exemplaren. Op de golf werd dwerggras op drie locaties gevonden tijdens de inventarisatie in 2003. Daarna is de soort er niet meer waargenomen.

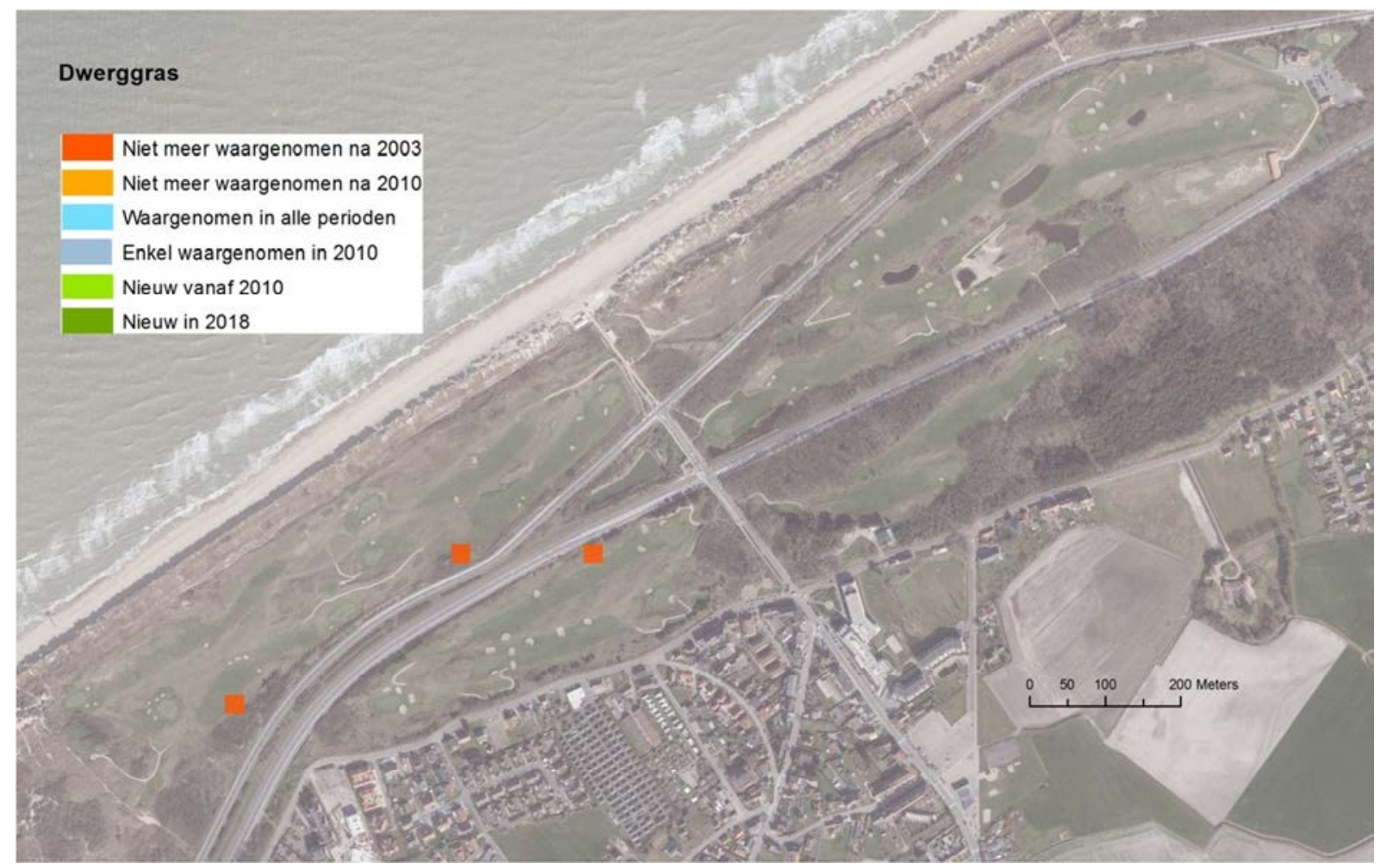




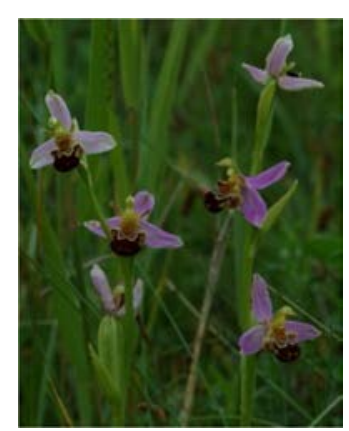

\section{Bijenorchis Ophrys apifera}

\section{RL: Zeldzaam}

Geschatte kustpopulatie: 500-5000 ind.

Geschatte populatie Golf: ?

Pioniersoort van droge tot vochtige kalkrijke bodem. In Vlaanderen is het een relatief zeldzame soort die recent regelmatig opduikt in bermen en op opgehoogde terreinen. Ook aan de kust zijn de groeiplaatsen vaak vrij kortstondig maar toch zijn er duidelijke zwaartepunten in de verspreiding. Zo is ongeveer de helft van de populatie te vinden in de omgeving van de Sashul in Heist. In 2003 werd een aantal exemplaren waargenomen ten noorden van de tee van hole 7. Tijdens de karteringen van 2010 en 2018 werd bijenorchis niet teruggevonden op de golf, ondanks een waarneming door een natuurminnende speler in 2016 (Anoniem 2016). De soort werd ook reeds vermeld voor het golfterrein door Verboven (1980).

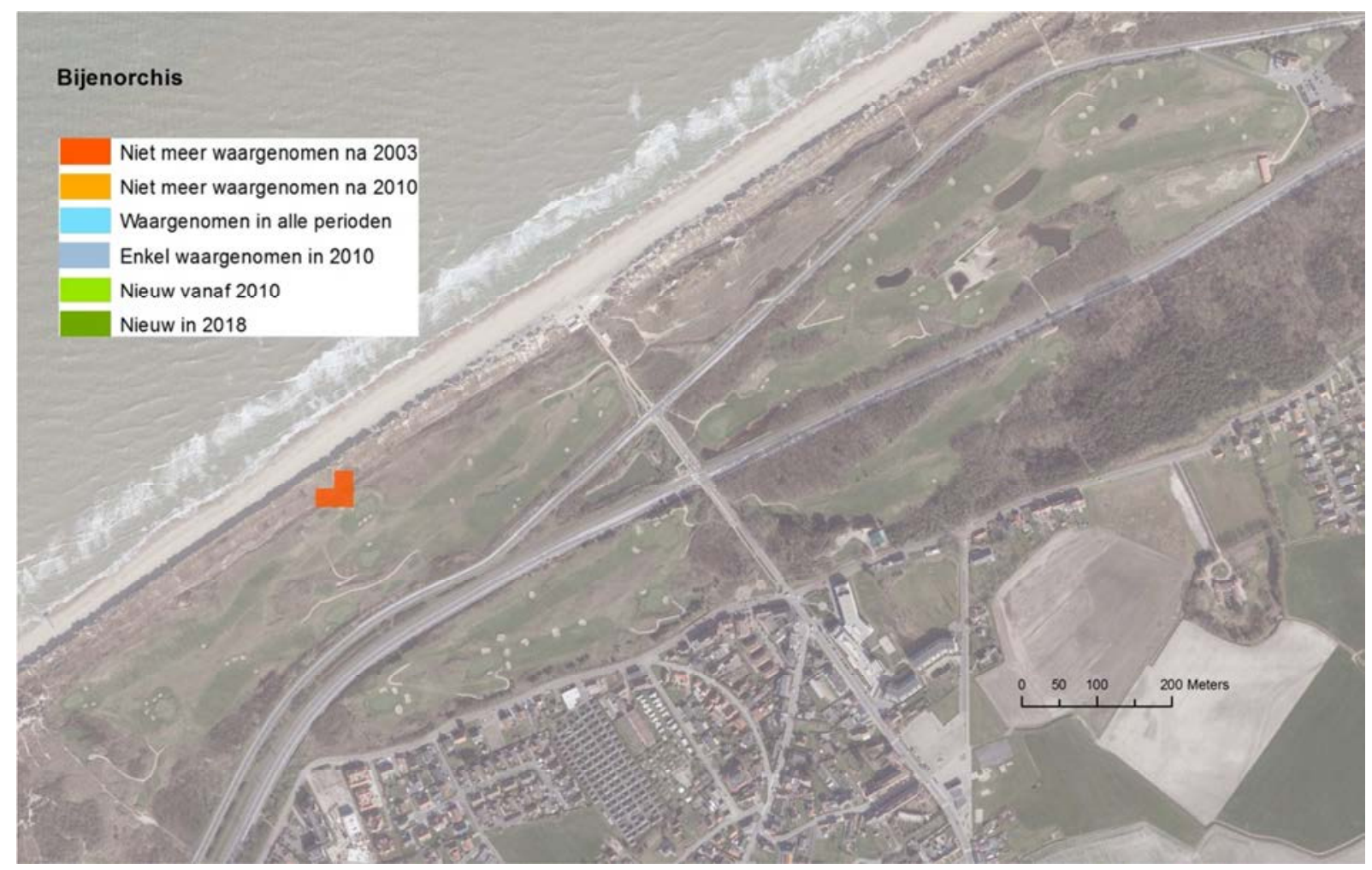




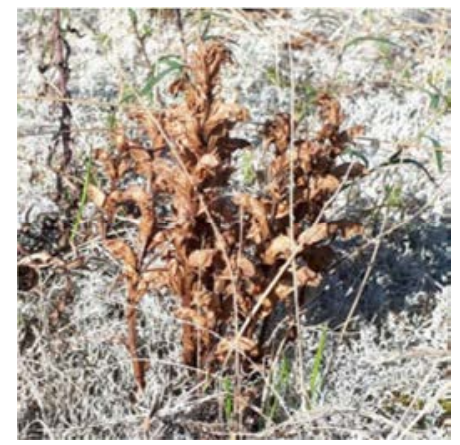

\title{
Walstrobremraap Orobanche caryophyllacea
}

\author{
RL: Bedreigd
}

Geschatte kustpopulatie: 5000-50000 ind.

Geschatte populatie Golf: 5-25 ind.

Een bladgroenloze plantensoort die parasiteert op verschillende soorten walstro en in Vlaanderen na 1972 enkel nog aan de kust is waargenomen. Daar groeit de soort vooral op geel walstro in jonge duingraslanden. Walstrobremraap is verspreid over de hele kust te vinden maar heeft duidelijke zwaartepunten in Ter Yde, het gebied rond de IJzermonding en de duinen van Middelkerke. Op de golf worden een aantal exemplaren van de soort waargenomen in de westelijke deelgebieden. De populatie lijkt de voorbije 15 jaar relatief stabiel.

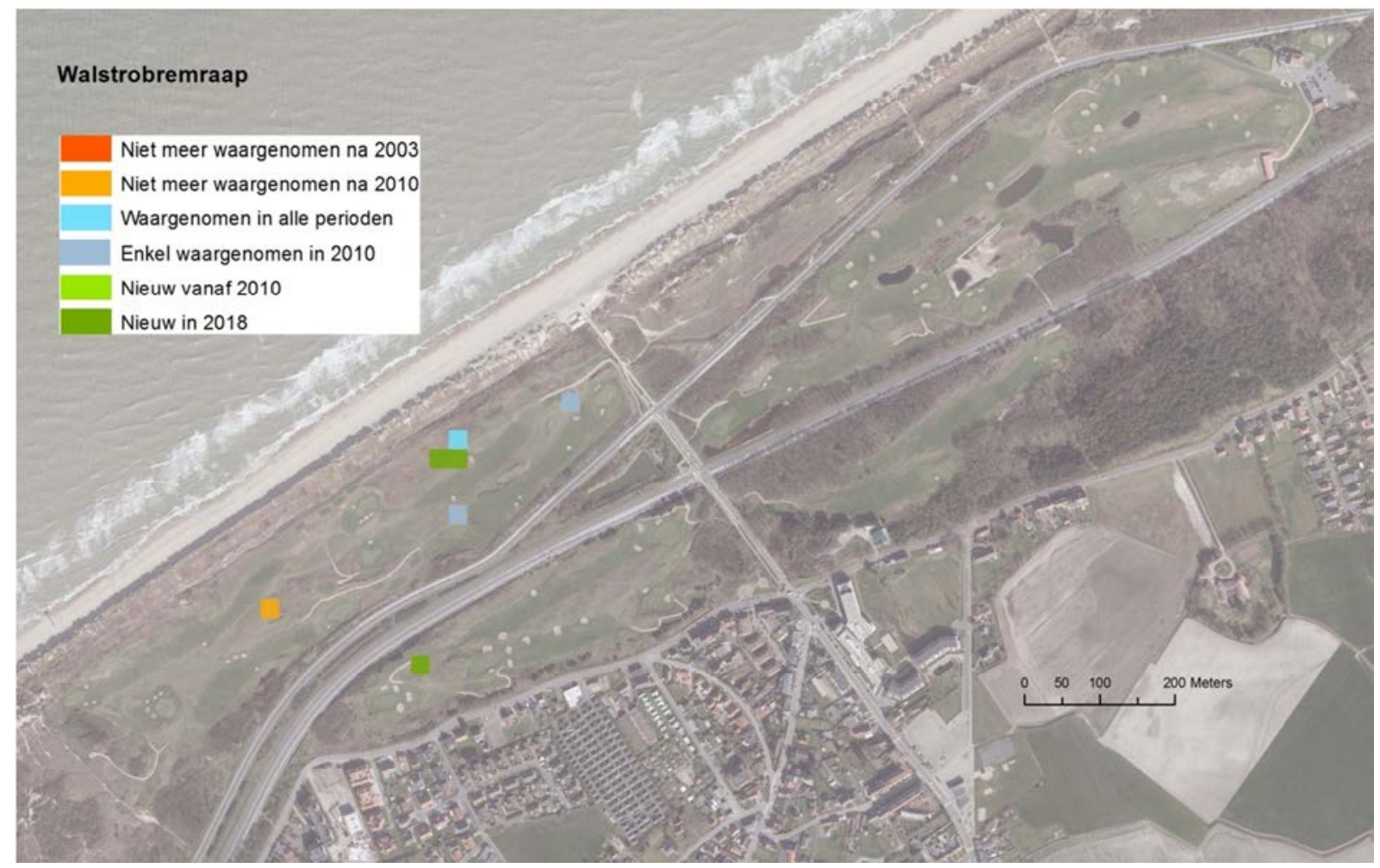




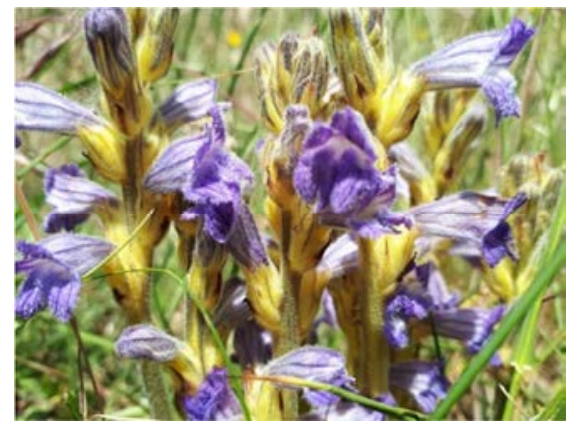

Blauwe bremraap Orobanche purpurea

\section{RL: Zeldzaam}

Geschatte kustpopulatie: 500-5000 ind.

Geschatte populatie Golf: 5-25 ind.

Parasiet van vooral duizendblad die groeit op droge, matig voedselarme bodems. In Vlaanderen is het een zeldzame soort die vooral in de duinstreek voorkomt. Daar is de soort verspreid te vinden in verschillende types relatief ruige graslanden. Op de golf is de soort in 2018 op vijf locaties gevonden. De populatiegrootte lijkt vrij stabiel de voorbije 15 jaar maar vertoont wel een grote ruimtelijke dynamiek. Verboven (1980) heeft slechts één enkel exemplaar op de golf aangetroffen.

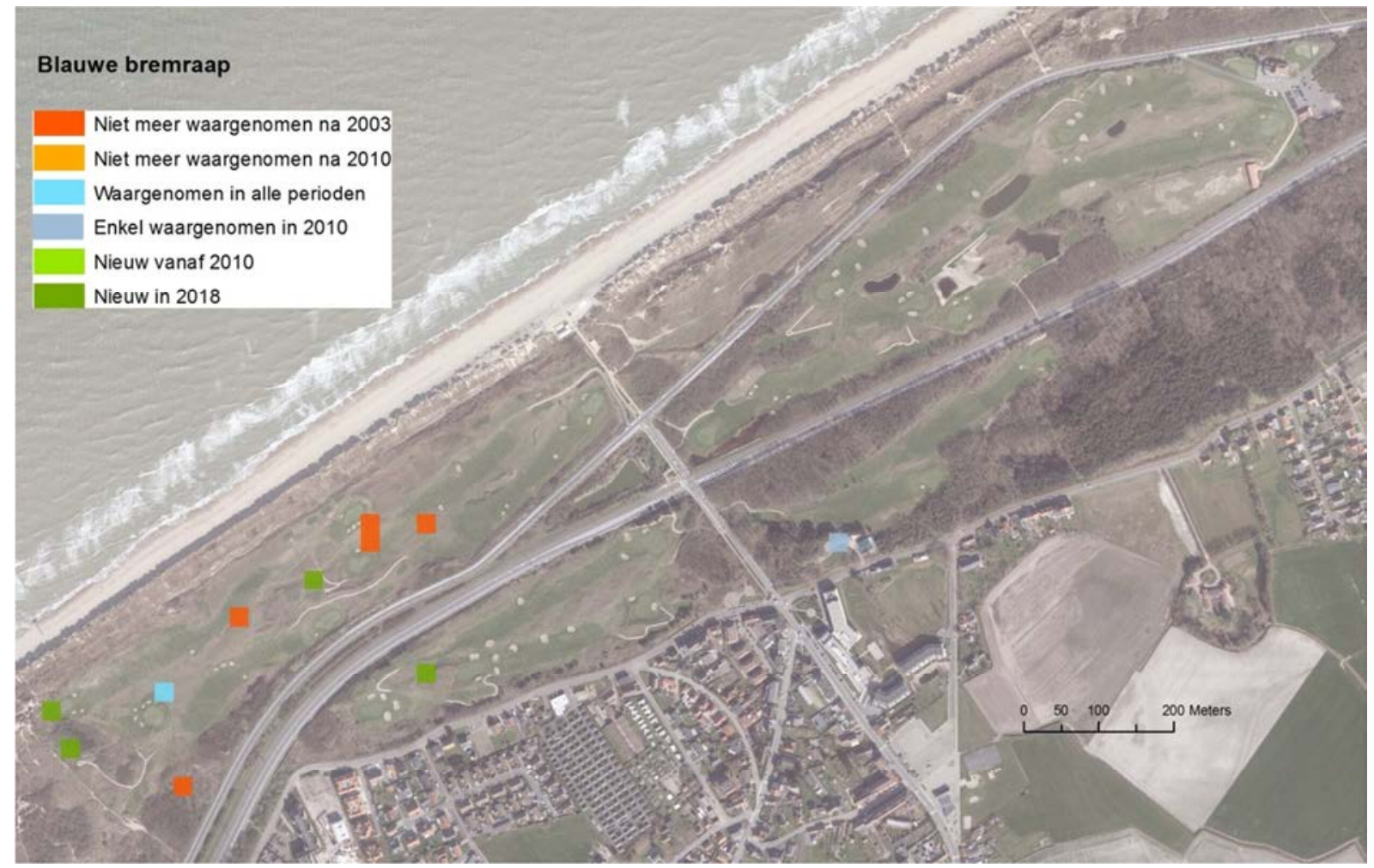




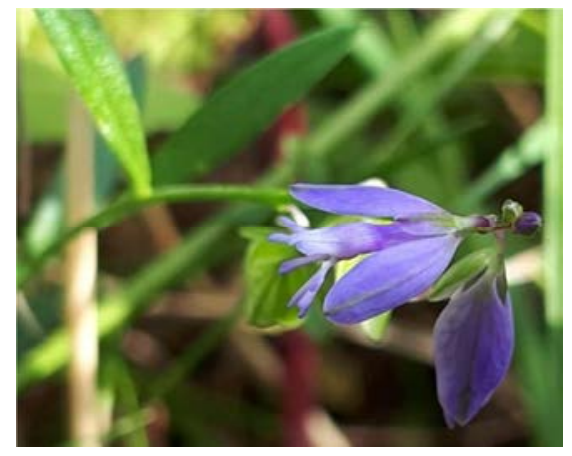

\section{Gewone vleugeltjesbloem Polygala vulgaris}

RL: Kwetsbaar

Geschatte kustpopulatie: > 50000 ind.

Geschatte populatie Golf: 25-50 ind.

Een soort van diverse voedselarme (vooral fosforarme) standplaatsen. In Vlaanderen is de soort zeer zeldzaam behalve aan de kust. Daar is het, vooral aan de Westkust, zelfs een lokaal algemene soort in vochtige pannen en duingraslanden. De soort heeft ook sterk geprofiteerd van de ontstruwelingen en is er vaak één van de eerste interessante soorten die opduikt. Op de golf worden enkele tientallen exemplaren waargenomen, vooral in het uiterste oosten en westen van het gebied. De populatie lijkt zich licht uit te breiden.

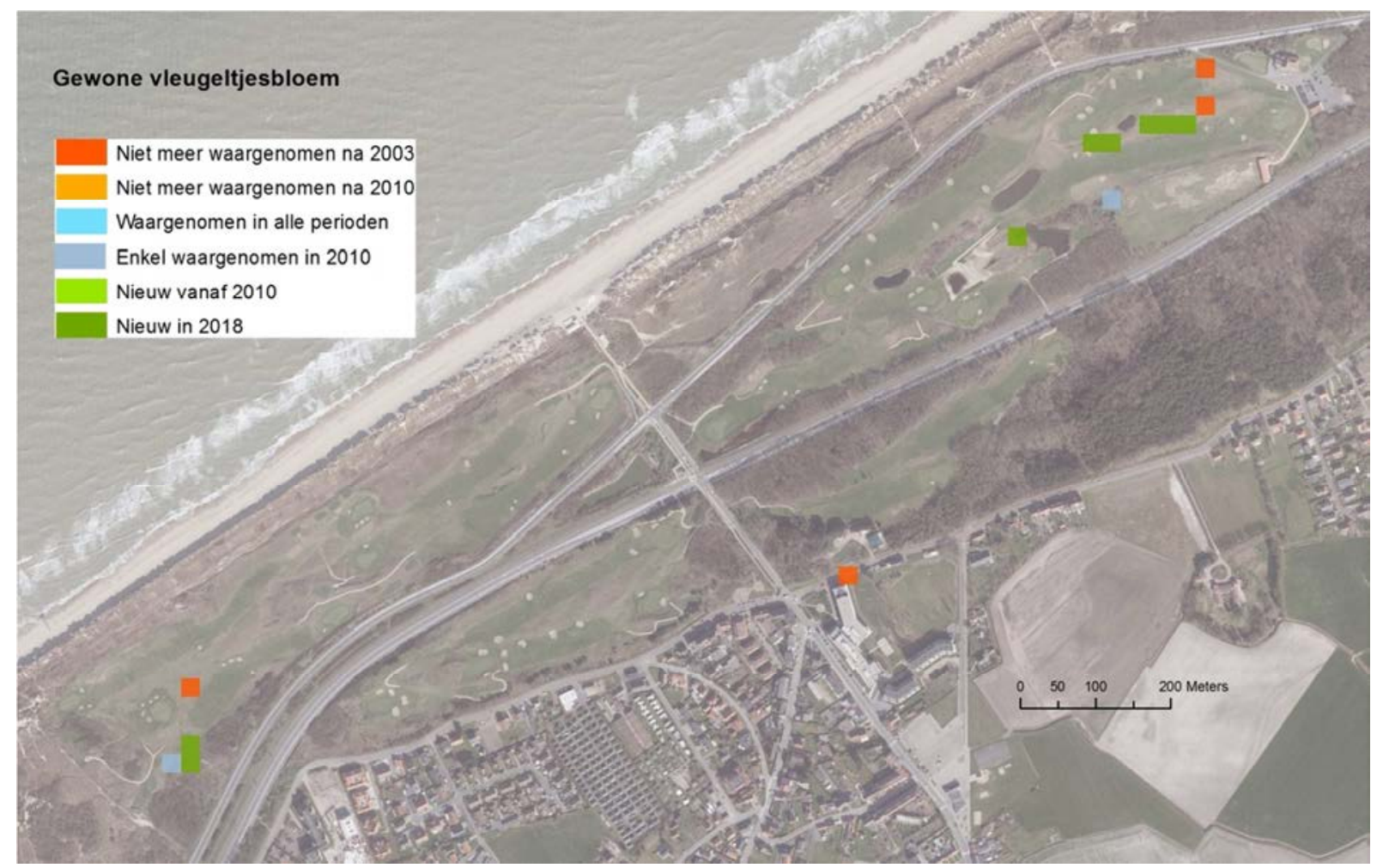




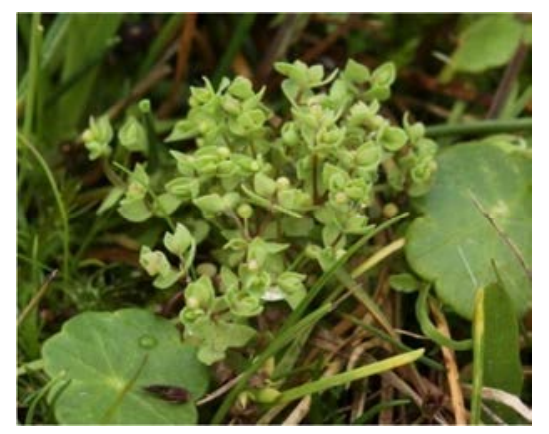

\section{Dwergvlas Radiola linoides}

RL: Met verdwijning bedreigd

Geschatte kustpopulatie: 2-5 ind.

Geschatte populatie Golf: -

Pionier van vochtige tot natte, voedselarme en zwak zure bodem (Nanocyperion). In Vlaanderen bijzonder zeldzaam en sterk achteruitgegaan. De meeste resterende groeiplaatsen bevinden zich in de Kempen. In 2003 werd de soort op twee locaties op de golf waargenomen door Arnout Zwaenepoel. Recenter zijn er geen waarnemingen meer bekend.

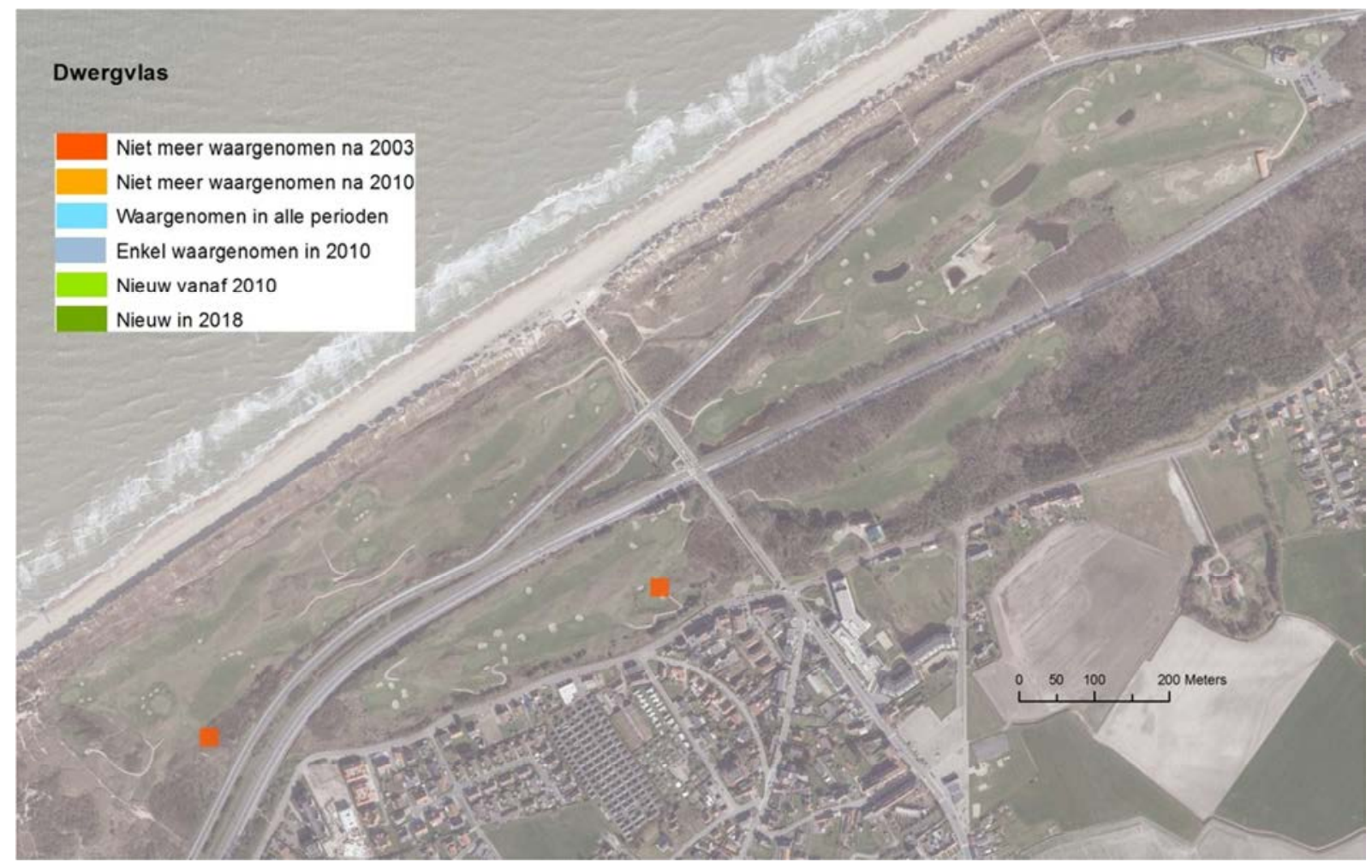




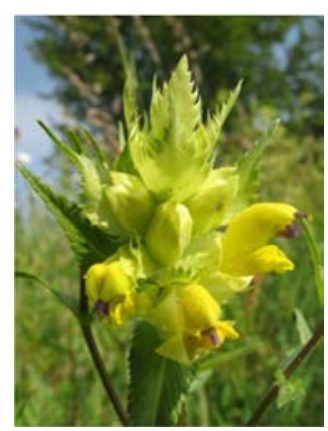

Grote ratelaar Rhinanthus angustifolius

RL: Kwetsbaar

Geschatte kustpopulatie: >50 000 ind.

Geschatte populatie Golf: 500-5000 ind.

Halfparasiet op grassen van vochtige tot natte, matig voedselrijke graslanden, vooral hooilanden. In Vlaanderen nog verspreid aan te treffen maar in de loop van de $20^{\text {ste }}$ eeuw sterk achteruitgegaan. Aan de kust heeft grote ratelaar zich recent spectaculair uitgebreid door het sterk toegenomen maaibeheer en het daarmee gepaard gaand vervoer van zaden. Fraaie ratelaarhooilanden zijn er te vinden in verschillende gebieden zoals o.m. Ter Yde, Groenendijk, D'Heye en de Fonteintjes. Op de golf werd grote ratelaar in de drie perioden waargenomen. In het noordwestelijke terreindeel, ten noorden van hole 7, heeft de soort zich sterk uitgebreid. Uitgebloeid zijn grote en kleine ratelaar doorgaans niet van elkaar te onderscheiden en in het veld wordt dan ook vaak "ratelaar spec." genoteerd. Dit geeft mogelijk een vertekening van de verspreidingspatronen (bv. ten zuiden van hole 12). In tabel 3.2 zijn de aantallen daarom in italics weergegeven.

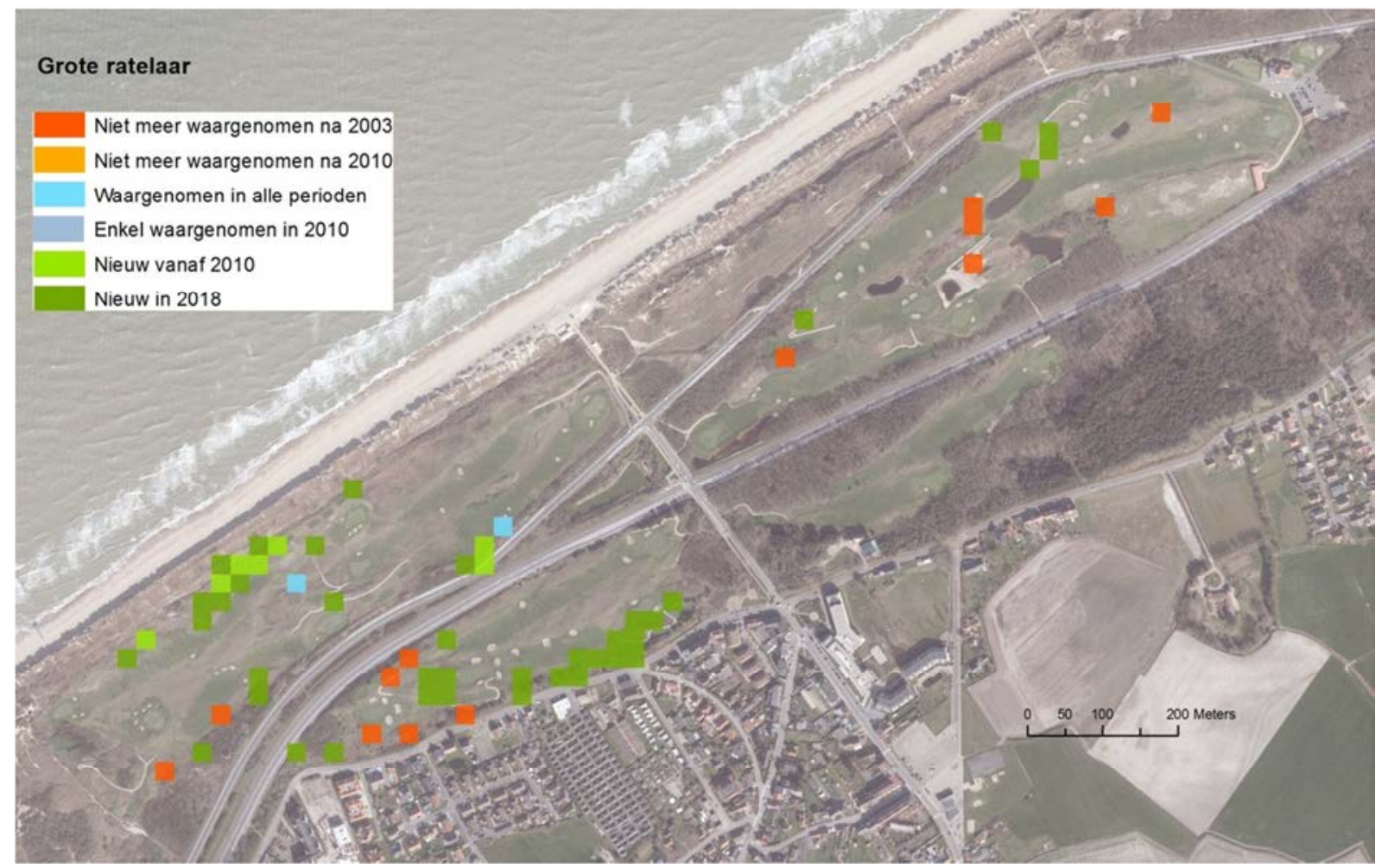




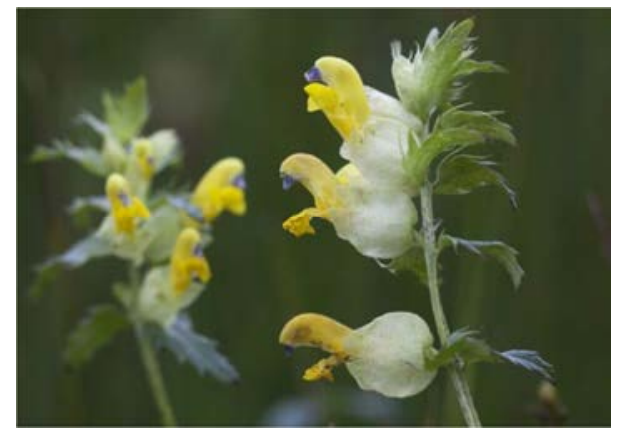

Kleine ratelaar Rhinanthus minor

RL: Kwetsbaar

Geschatte kustpopulatie: >50 000 ind.

Geschatte populatie Golf: 5000-50 000 ind.

Net als grote ratelaar een halfparasiet op grassen maar met een verschillende ecologie. Kleine ratelaar verkiest drogere en kalkrijkere standplaatsen hoewel ze samen kunnen voorkomen en ook kruisen. In Vlaanderen vertoont de (althans recente) verspreiding van deze soort duidelijke zwaartepunten aan de kust en aan de Maas. Kleine ratelaar is relatief frequent te vinden in droge duingraslanden verspreid over de hele kust. Op de golf is kleine ratelaar één van de meest algemene aandachtssoorten die verspreid over het hele terrein kan worden gevonden. Verspreiding en populatiegrootte zijn vermoedelijk relatief stabiel (zie opmerking bij grote ratelaar).

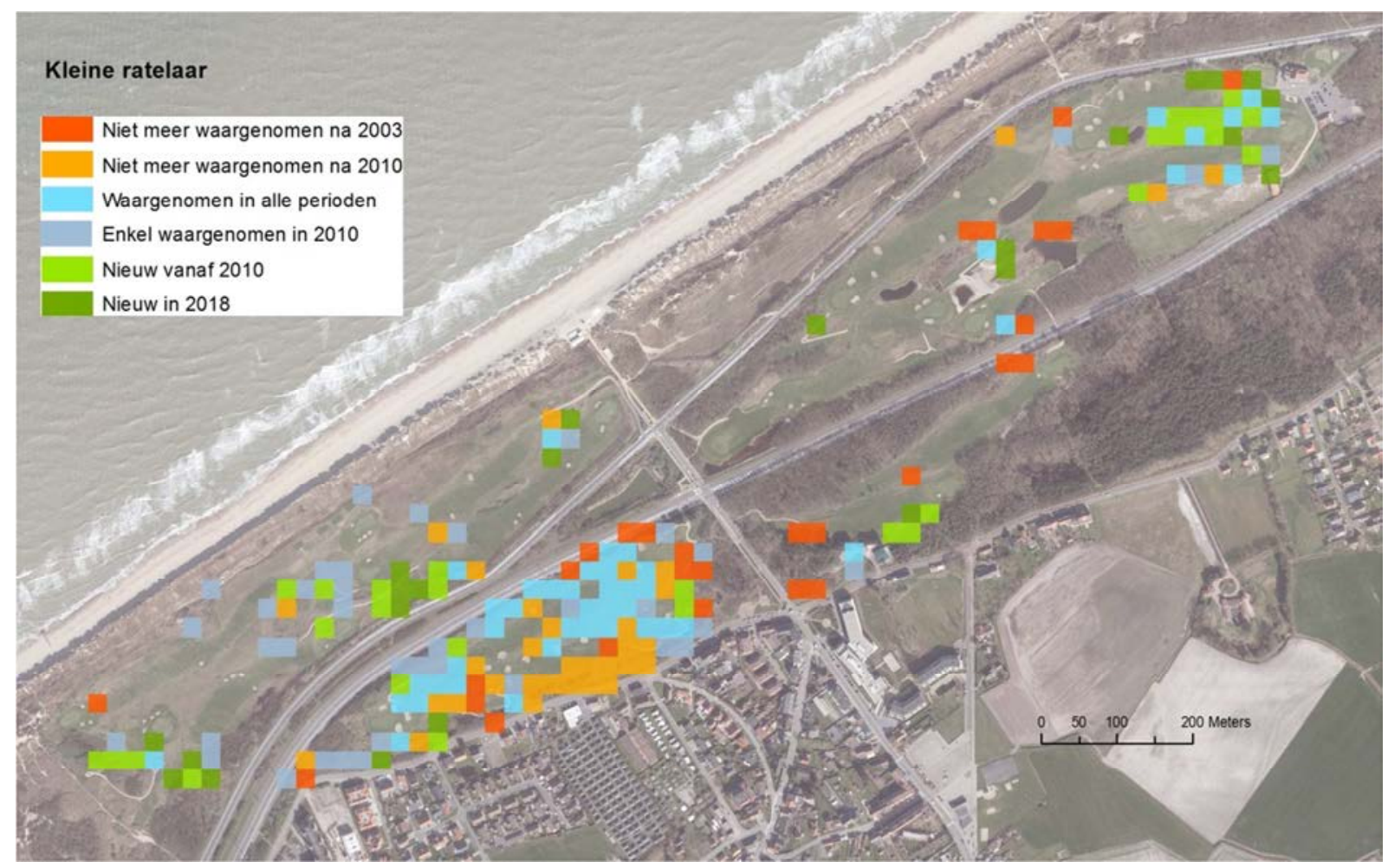




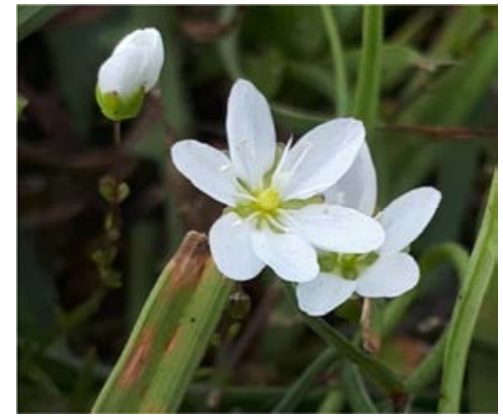

\section{Sierlijke vetmuur Sagina nodosa}

RL: Momenteel niet bedreigd

Geschatte kustpopulatie: > 50000 ind.

Geschatte populatie Golf: 25-50 ind.

Pionier van voedselarme, doorgaans vochtige bodems. In de duinen vooral in jonge duinvalleien, op open plekken in sommige vochtige graslanden en massaal in de zilte mosduinen van de Baai van Heist. De Westhoek en Heist zijn samen goed voor $85 \%$ van de kustpopulatie. Op de golf werd sierlijke vetmuur enkel in 2018 gekarteerd. De soort dook op in de herstelde duinvallei aan hole 17.

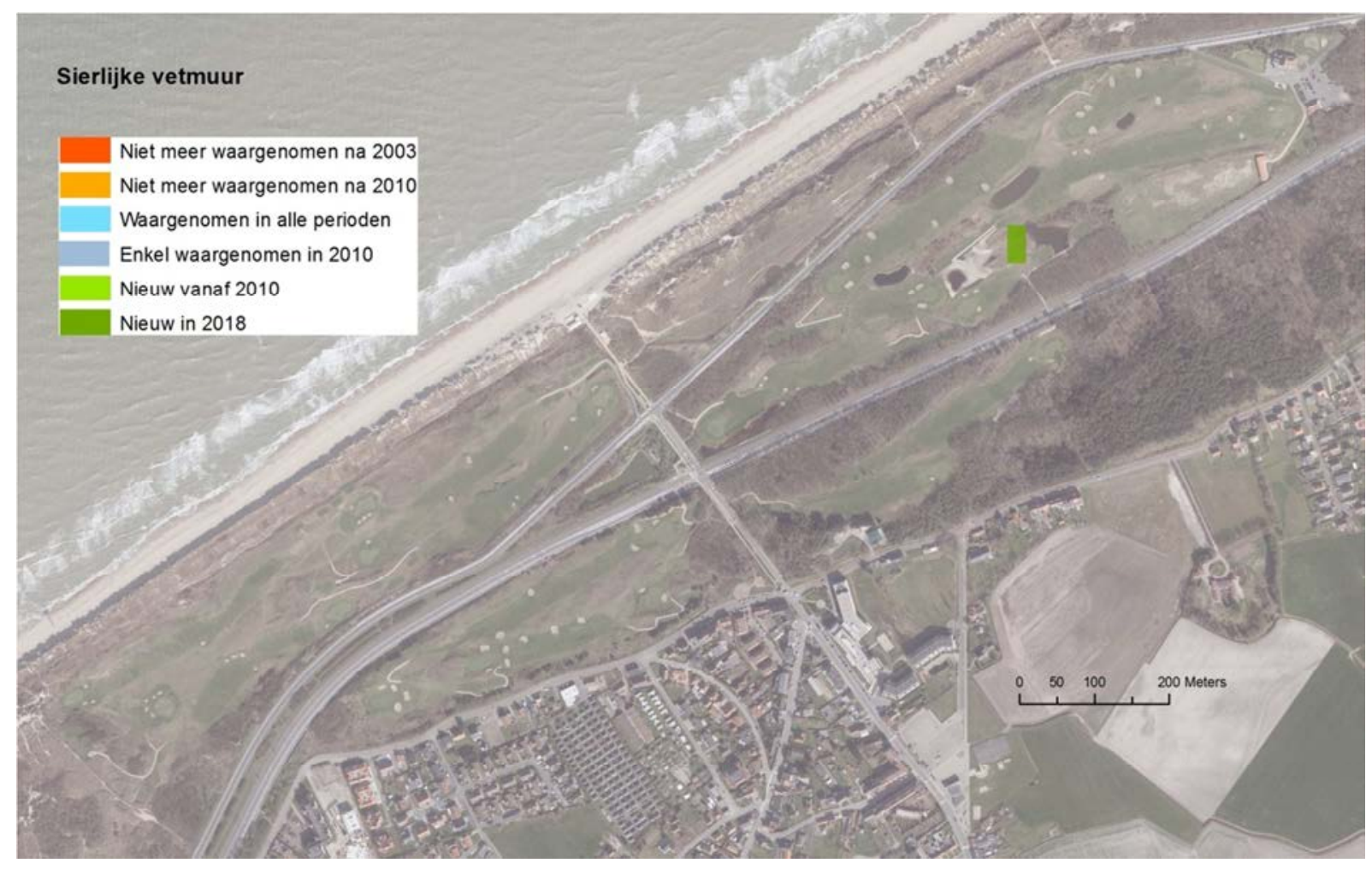




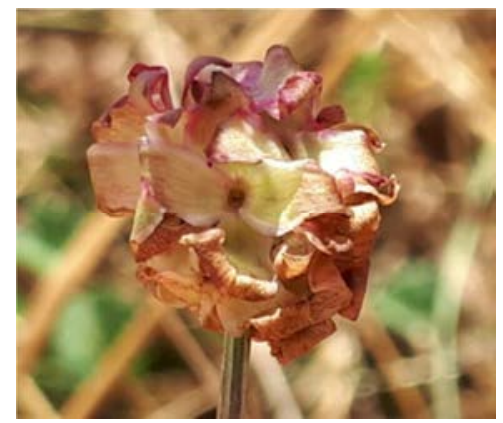

Kleine pimpernel Sanguisorba minor

RL: Momenteel niet bedreigd

Geschatte kustpopulatie: 50-500 ind.

Geschatte populatie Golf: 5-25 ind.

Een soort van kalkrijke, voedselarme graslanden die in Vlaanderen vooral aan de Maas en in de Voerstreek te vinden is. Aan de kust gekend van beperkt aantal groeiplaatsen in Koksijde en van de Golf in De Haan. Daar is de soort vermoedelijk nooit algemeen geweest. Verboven (1980) vond kleine pimpernel op drietal plaatsen. Ook in 2003 werden nog drie groeiplaatsen vastgesteld maar in 2010 en 2018 werd de soort op nog slechts één locatie gevonden (twee naburige hokken van $25 \times 25 \mathrm{~m}^{2}$ ). Dit maakt de soort binnen het gebied bijzonder kwetsbaar.

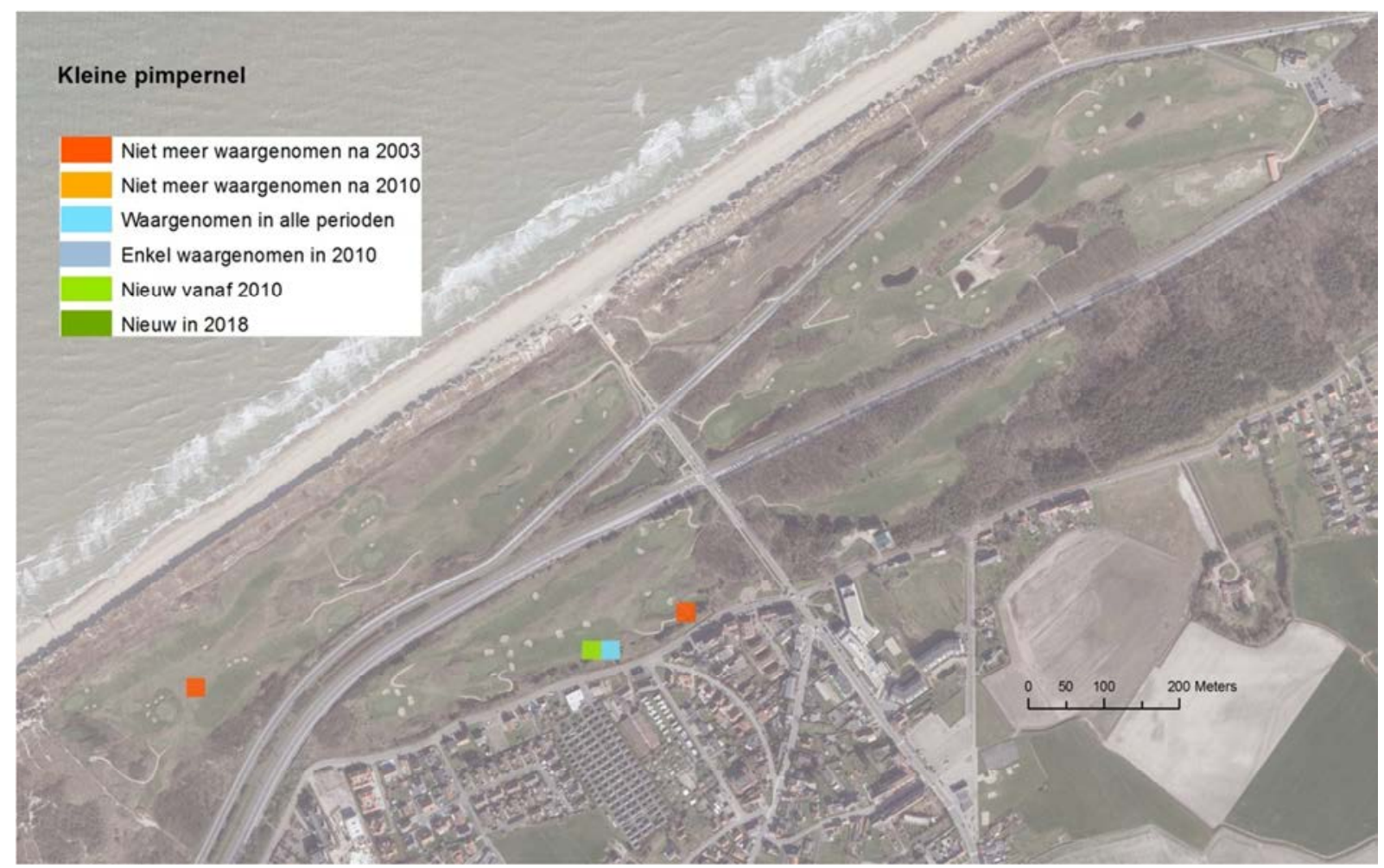




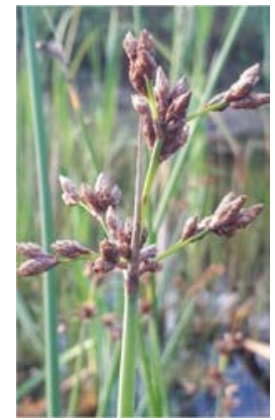

\section{Ruwe bies Schoenoplectus tabernaemontani}

RL: Momenteel niet bedreigd

Geschatte kustpopulatie: $50-500 \mathrm{~m}^{2}$

Geschatte populatie Golf: 5-25 m²

Een soort van oevers en zeer natte plaatsen met basenrijk, soms brak water. In Vlaanderen is het vooral een poldersoort en ook dichter tegen de kust komt de soort veelal in duin-polder overgangssituaties voor. De grootste populatie binnen de duinstreek bevindt zich in de ontboste delen van Hannecart (Doolaeghe). Op de golf werd een aantal exemplaren van de soort gevonden in 2018. Ruwe bies dook op in de uitgegraven natte depressie aan hole 4. De soort vormt een langlevende bodemzaadvoorraad, net zoals veel andere soorten biezen, russen en zeggen. Historisch is de soort ook bekend van het gebeid (Van Landuyt et al. 2006).

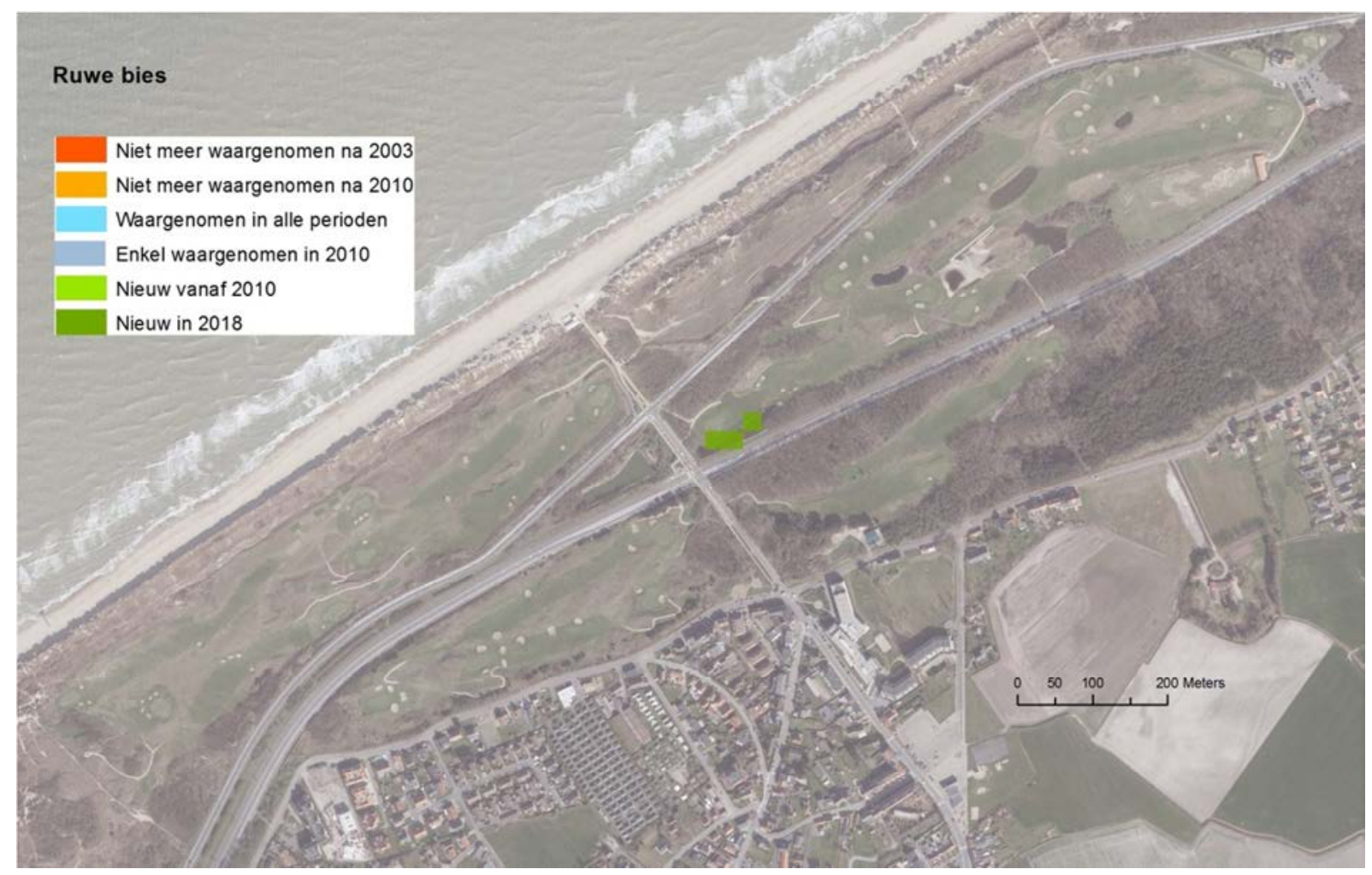




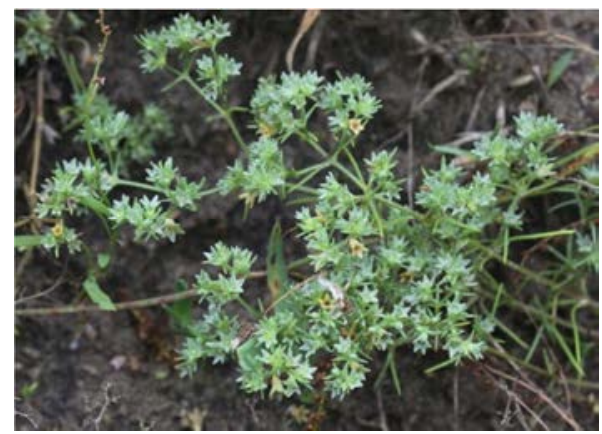

\title{
Eenjarige hardbloem Scleranthus annuus
}

\author{
RL: Achteruitgaand
}

Geschatte kustpopulatie: 500-5000 ind.

Geschatte populatie Golf: 500-5000 ind.

Pionier op open, schrale en (zwak) zure bodems. In Vlaanderen is het een algemene soort in de regio's met zure zandgrond. Aan de kust is de soort zeldzaam en vooral gekend van de oude, ontkalkte duingebieden Cabour en D'Heye. Verboven (1980) vermeld de soort in enkele opnames op de golf. In 2003 werd eenjarige hardbloem slechts op één locatie vastgesteld en in 2010 werd de soort niet gevonden. Er lijkt dus sprake van een aanzienlijke uitbreiding gezien de soort in 2018 in 16 hokken werd gevonden (vooral in het noorwestelijk deelgebied). De soort groeit er nagenoeg uitsluitend op de semi-rough.

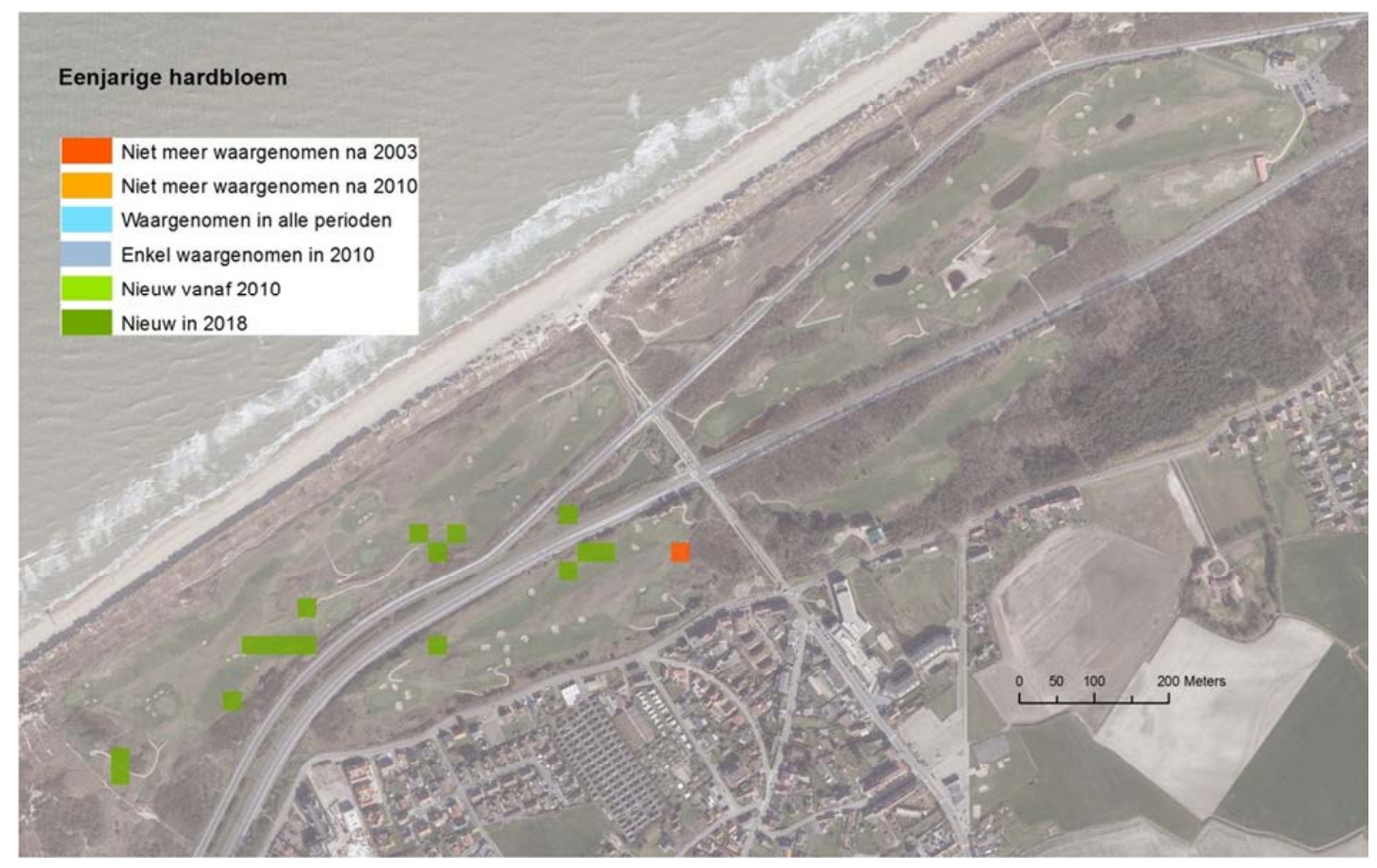




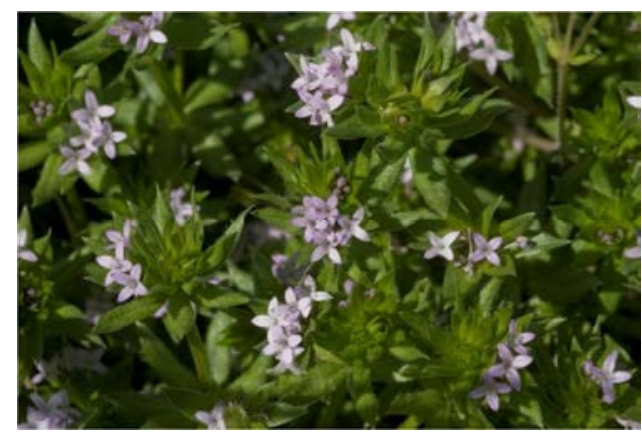

\section{Blauw walstro Sherardia arvensis}

RL: Momenteel niet bedreigd

Geschatte kustpopulatie: 50-500 $\mathrm{m}^{2}$

Geschatte populatie Golf: 2-5 $\mathrm{m}^{2}$

Een soort van korte, droge tot vochtige kalkhoudende graslanden en pioniersituaties. In Vlaanderen is het een vrij zeldzame soort met een voorkeur voor de kuststreek en de oostelijke leemstreek. Aan de kust wordt blauw walstro verspreid aangetroffen in gazons en wegbermen. Op de golf in 2003 op twee locaties en in 2018 op één (andere) locatie waargenomen. Indien niet bloeiend wordt de soort gemakkelijk over het hoofd gezien.

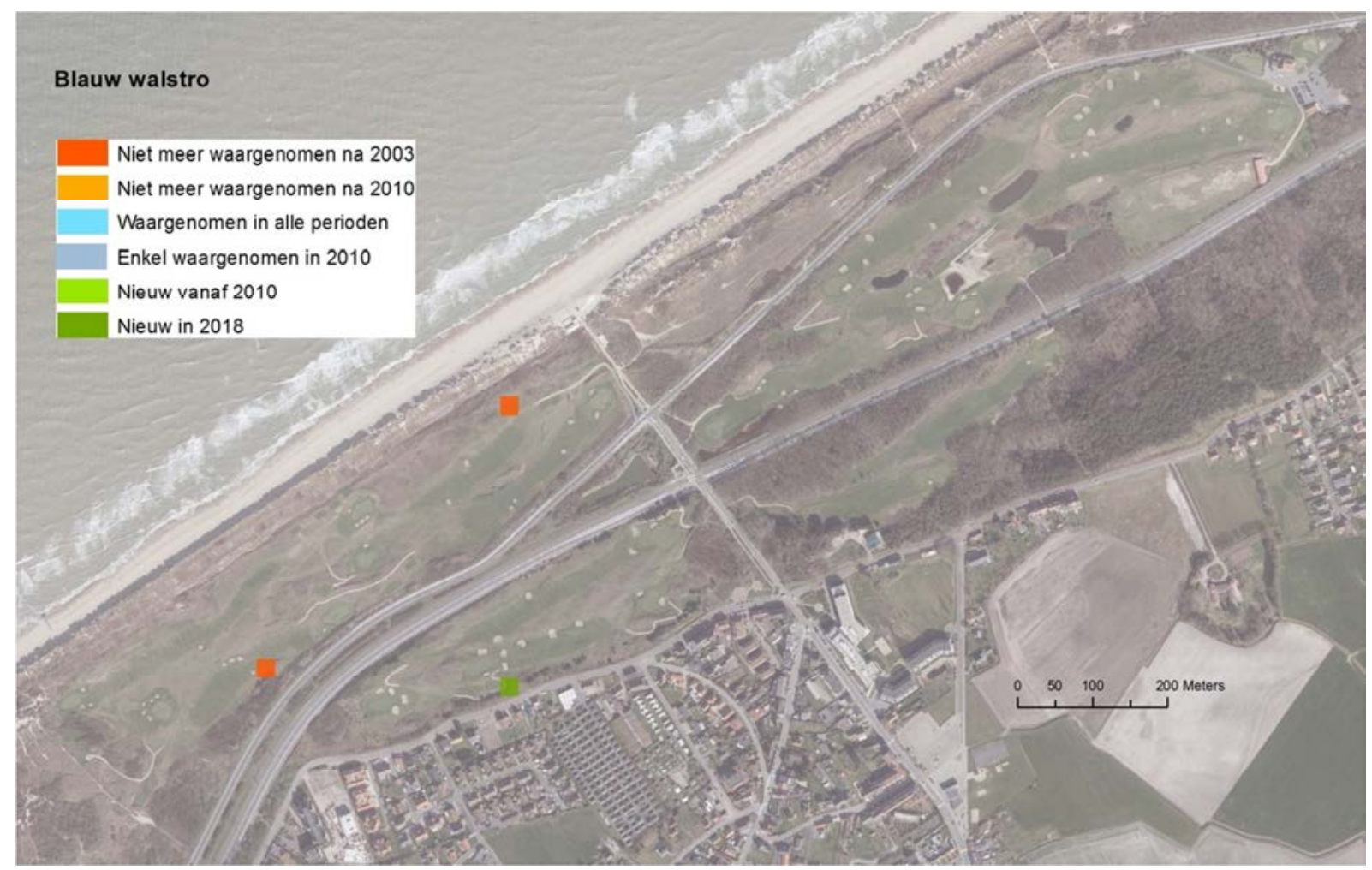




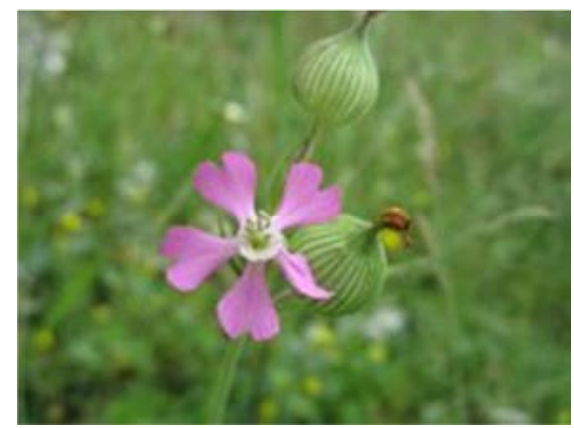

\section{Kegelsilene Silene conica}

\section{RL: Zeldzaam}

Geschatte kustpopulatie: 5000-50 000 ind.

Geschatte populatie Golf: 50-500 ind.

In Noordwest-Europa een soort van droge, kalkrijke en licht geruderaliseerde open duinen. Vrij algemeen aan onze kust (en heel sporadisch adventief in het binnenland) maar grotendeels in antropogene milieus. De bermen van de Koninklijke Baan vormen bijvoorbeeld één van de favoriete standplaatsen. Op de golf wordt de soort enkel in de westelijke terreindelen gevonden. Het aantal vindplaatsen (hokken) is teruggelopen van 12 in 2003 tot 5 in 2018 . Een waarschijnlijke oorzaak hiervan is de successie van mosduinen naar duingrasland.

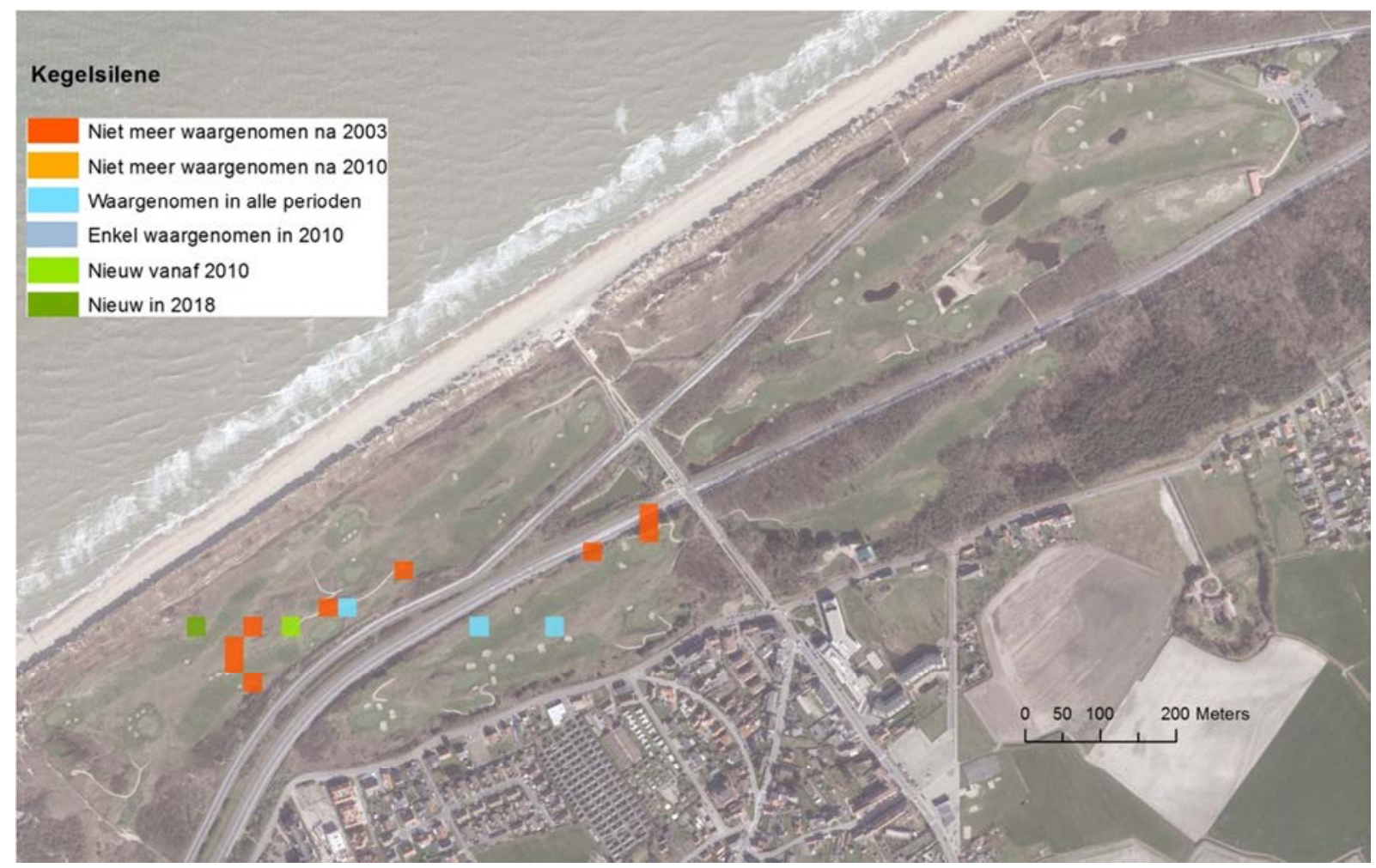




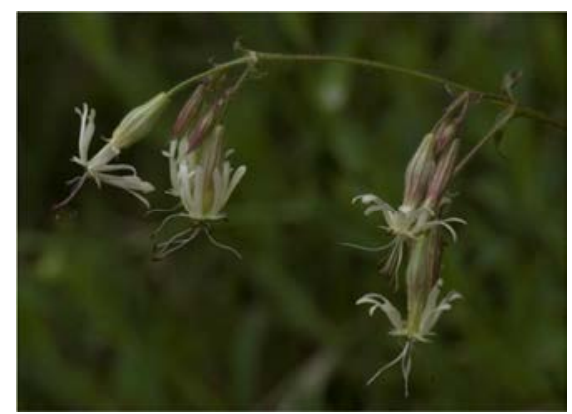

Nachtsilene Silene nutans

RL: Zeldzaam

Geschatte kustpopulatie: 5000-50 000 ind.

Geschatte populatie Golf: -

Een soort van droge kalkgraslanden en rotsen die in Vlaanderen nagenoeg uitsluitend aan de kust gevonden wordt. Belangrijke populaties zijn te vinden aan de Westkust, de Warandeduinen in Middelkerke en de golf van Knokke. Nachtsilene wordt niet vermeld voor de golf door Verboven (1980), maar is historisch wel gekend van het gebied (Van Landuyt et al. 2006). In 2003 werden nog enkele individuen waargenomen op twee verschillende plaatsen maar in 2010 en 2018 werd de soort niet meer teruggevonden. Indien de soort er effectief verdwenen is, betekent dit dat nachtsilene aan de kust actueel niet meer voorkomt tussen de Warandeduinen in Middelkerke en Park 58 in Knokke, hoewel de soort historisch aan nagenoeg de hele kust werd gevonden (Van Landuyt et al. 2006).

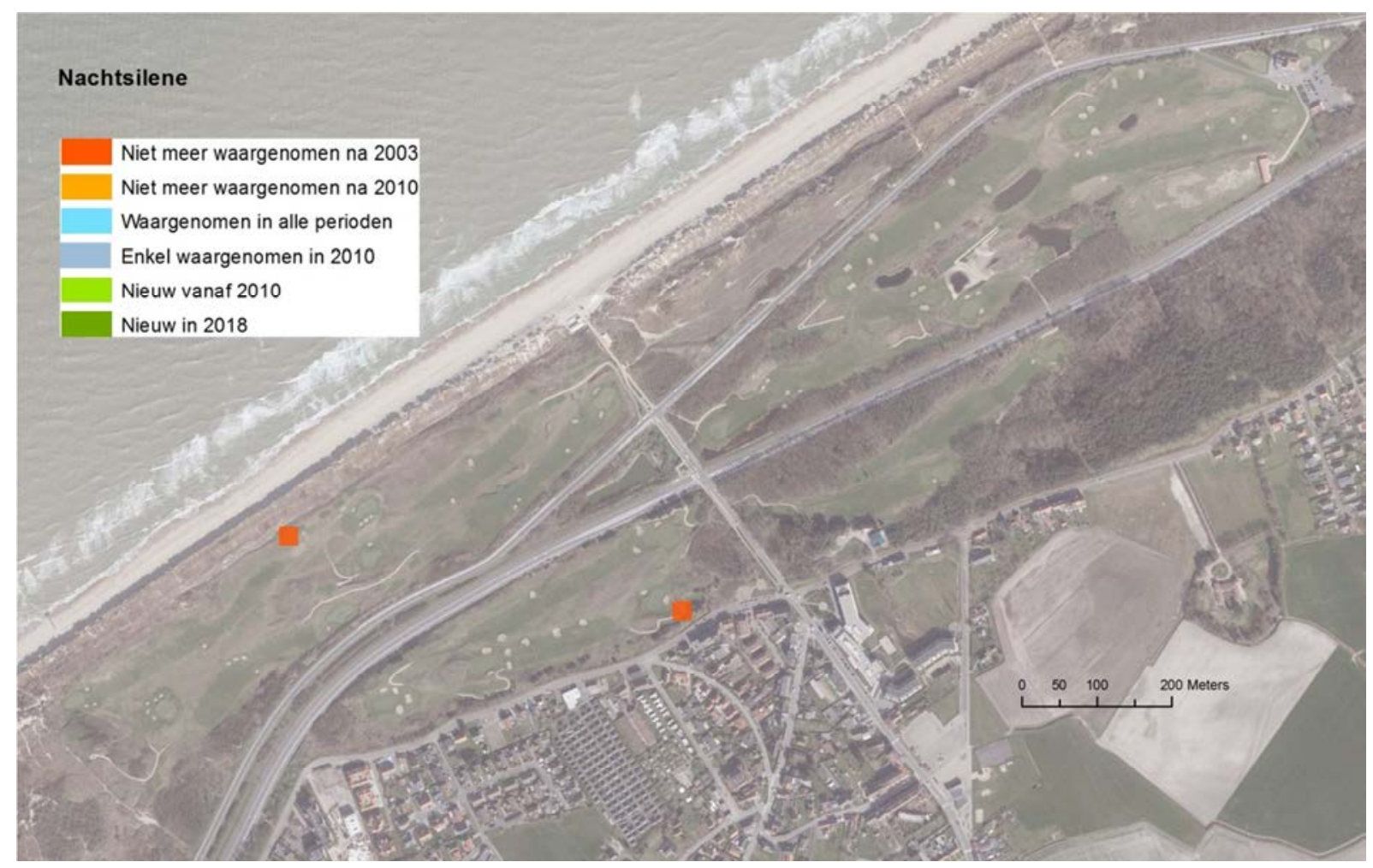




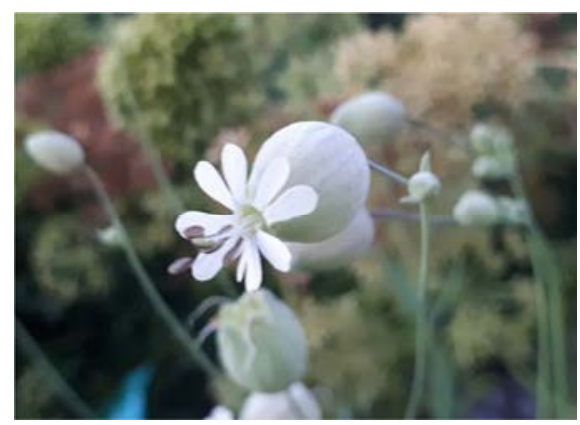

Blaassilene Silene vulgaris

RL: Momenteel niet bedreigd

Geschatte kustpopulatie: 5000-50 000 ind.

Geschatte populatie Golf: -

Een soort van kalkrijke graslanden en pioniersituaties. In Vlaanderen verspreid aanwezig en zich uitbreidend in antropogene milieus. Aan de kust recent bekend van enkele waarnemingen, vaak te relateren aan tuinontsnappingen. Op de golf van De Haan werden in 2003 enkele individuen aangetroffen ten zuiden van hole 12 . $\mathrm{Zij}$ werden niet meer gevonden tijdens de daaropvolgende inventarisaties in 2010 en 2018.

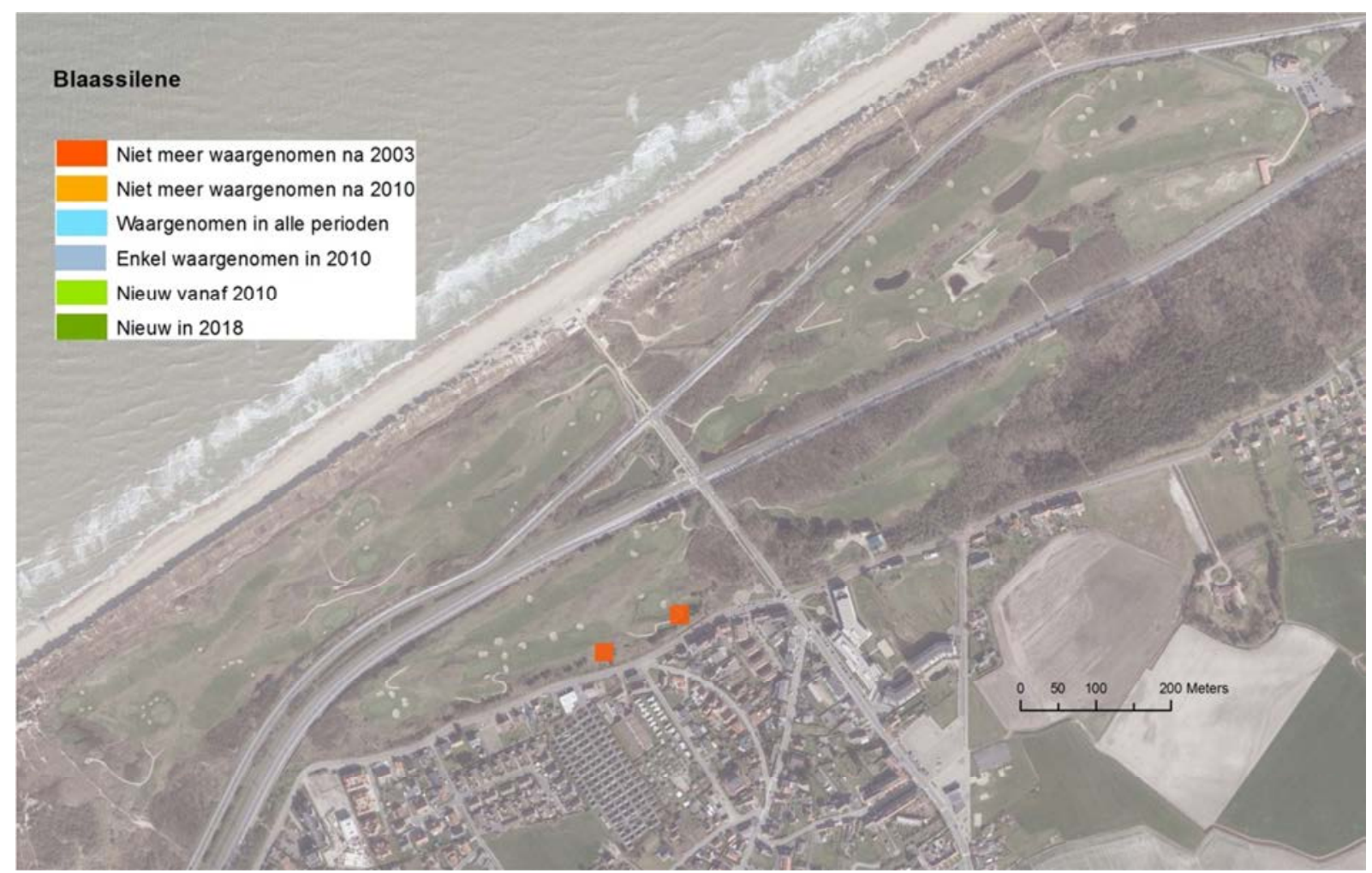




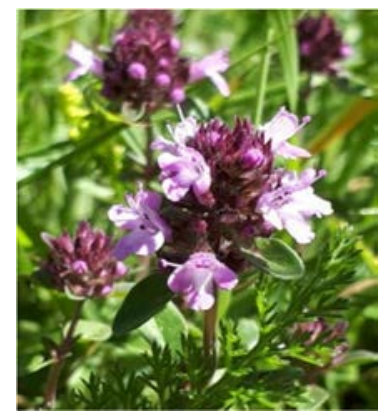

Grote tijm Thymus pulegioides

RL: Kwetsbaar

Geschatte kustpopulatie: 5000-50 $000 \mathrm{~m}^{2}$

Geschatte populatie Golf: $50-500 \mathrm{~m}^{2}$

Een soort van droge tot vochtige, schrale graslanden. In Vlaanderen vrij zeldzaam met zwaartepunten in de kustduinen, langs de Maas en in de oostelijke leemstreek. Grote tijm komt voor in duingraslanden verspreid over de kust. Het is vaak de laatste soort die bij degradatie van graslanden het loodje legt en daarom nog ruimer verspreid dan andere graslandsoorten zoals nachtsilene, geel zonneroosje of liggend bergvlas. Aan de hele Westkust is het een vrij algemene verschijning maar verder oostwaarts is de verspreiding beperkt tot een aantal gebieden: StLaureinsduinen, Warandeduinen, golf van De Haan, golf van Knokke en Zwinduinen. Op de golf is een vrij grote populatie aanwezig, verspreid over een vijftigtal rasterhokken van $25 \times 25 \mathrm{~m}^{2}$. De soort lijkt er globaal relatief stabiel. Opvallende achteruitgang is er in de rough ten zuiden van hole 5. Die is nagenoeg volledig door klimop overgroeid, wat overleving van de karakteristieke graslandsoorten verhindert. De sterke uitbreiding op de flank van het Spanjaardduin, ten westen van hole 8 berust vermoedelijk op een gebrekkige inventarisatie in de vroegere periodes. Grote tijm is namelijk geen goede verbreider en het is dan ook onwaarschijnlijk dat de soort zich massaal heeft gevestigd in de sterk vergraste vegetatie.

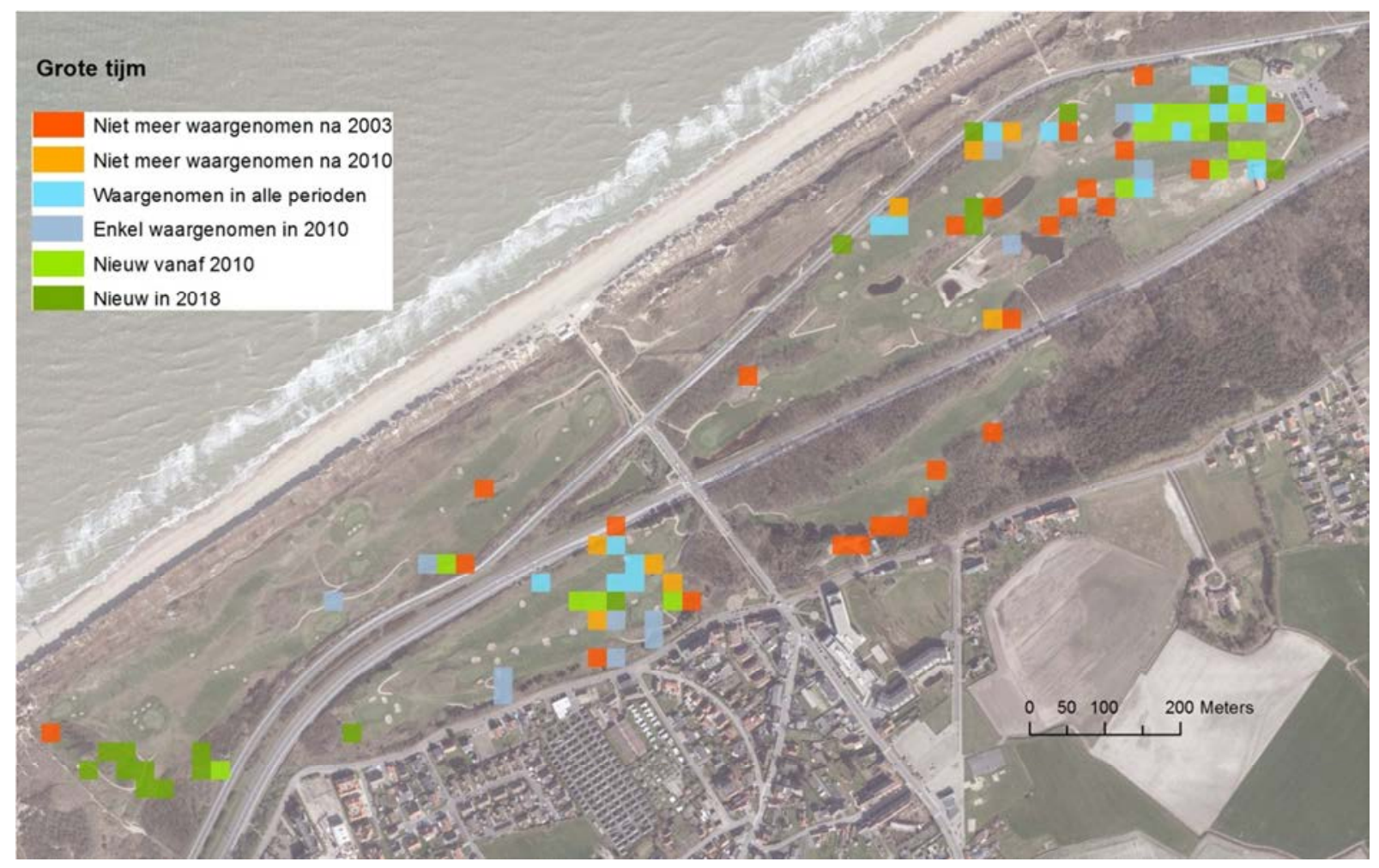




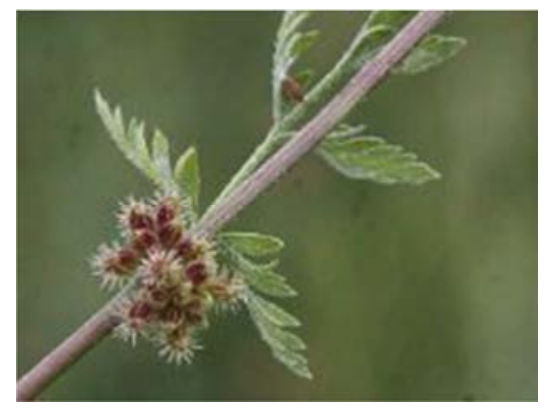

\section{Knopig doornzaad Torilis nodosa}

RL: Momenteel niet bedreigd

Geschatte kustpopulatie: 500-5000 ind.

Geschatte populatie Golf: -

Een soort van droge, open en graslanden die in Vlaanderen nagenoeg uitsluitend in de polders te vinden is. De soort wordt aangetroffen in de berm van de Driftweg net buiten de golf maar is wel een potentiële aandachtssoort voor het gebied.

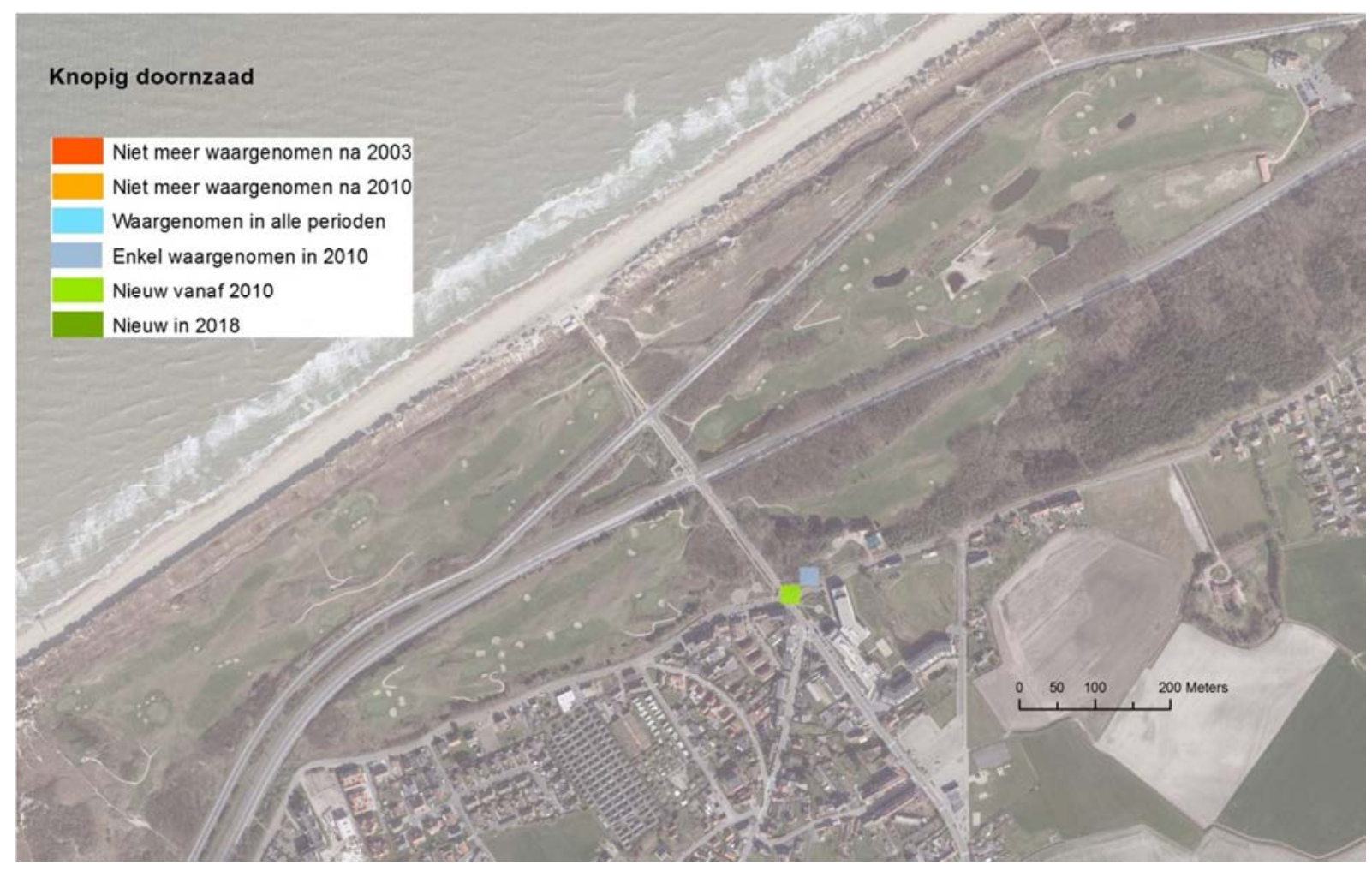




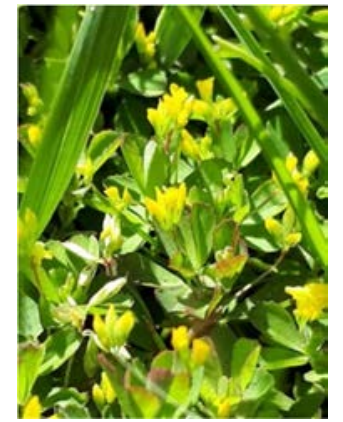

Draadklaver Trifolium micranthum

RL: Momenteel niet bedreigd

Geschatte kustpopulatie: > 50000 ind.

Geschatte populatie Golf: 500-5000 ind.

Een soort van korte, matig voedselrijke, droge tot vochtige graslanden. In Vlaanderen wordt de soort vooral aangetroffen op de intensief gemaaide gazons van de Commonwealth militaire kerkhoven rond Ieper (Van Landuyt et al. 2004). Aan de kust groeit het grootste deel van de populatie in de ontkalkte 'klavergraslanden' van D'Heye en Garzebekeveld-Cabour, samen met gestreepte en onderaardse klaver. Ook de fairways van de golfterreinen in De Haan en Knokke vormen een geschikte habitat voor de soort. In De Haan lijkt de soort zich recent sterk te hebben uitgebreid, van 25 hokken van $25 \times 25 \mathrm{~m}^{2}$ in 2003 tot 46 in 2018 . Het is de aandachtssoort met de meest uitgesproken voorkeur voor de korte gazons van de fairways en zelfs sommige tees en surrounds.

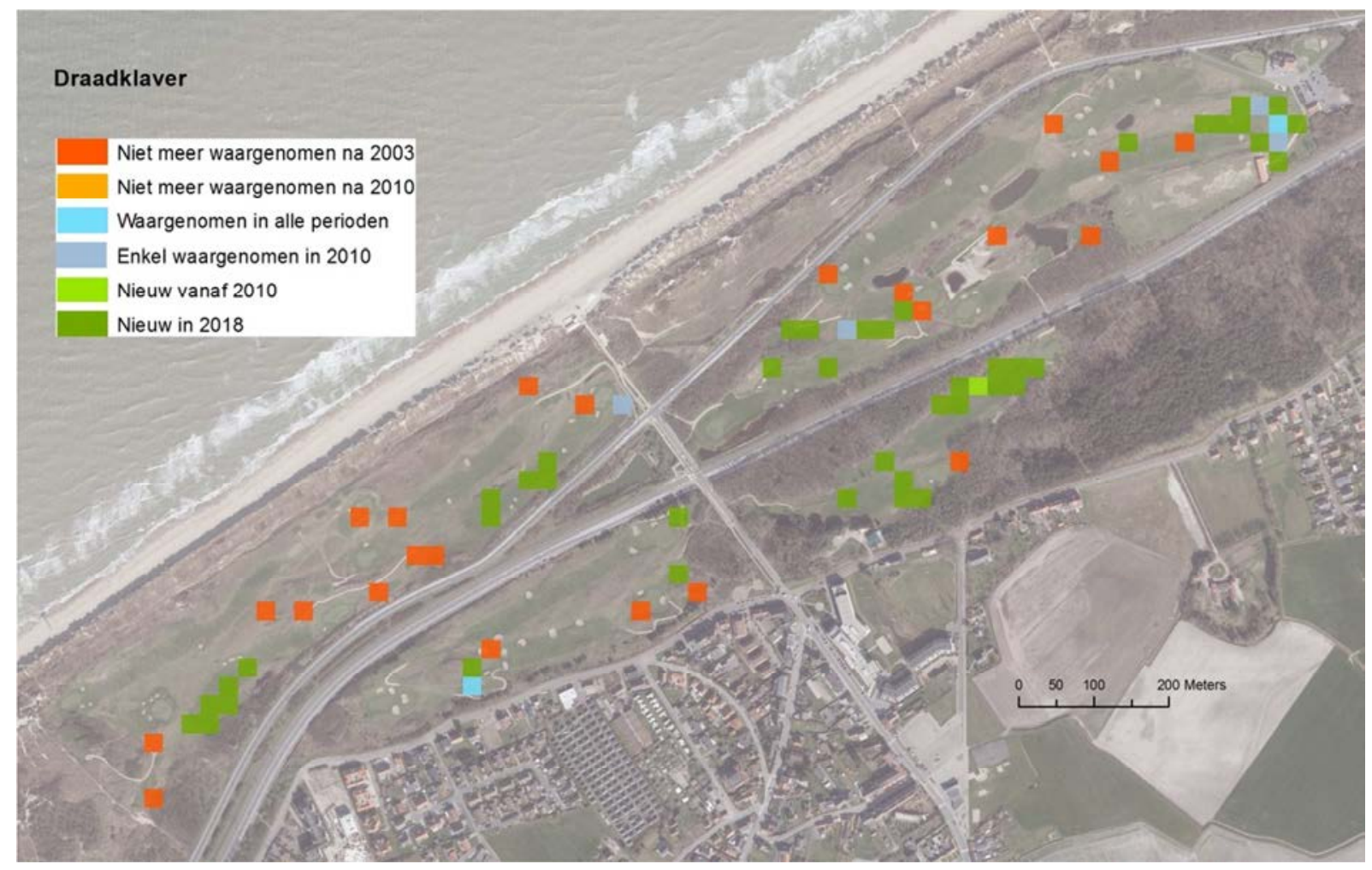




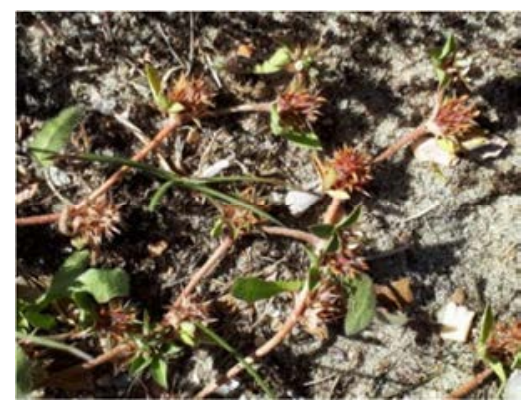

\section{Ruwe klaver Trifolium scabrum}

RL: Zeldzaam

Geschatte kustpopulatie: 5000-50 000 ind.

Geschatte populatie Golf: 5000-50 000 ind.

Eénjarige pionier van droge, open graslanden op kalkrijke tot neutrale bodem. Het is een Atlantisch-Mediterrane soort die in Vlaanderen nagenoeg beperkt is tot de kustduinen. Daar groeit ze in zandige wegbermen en zeer schrale gazons en duingraslanden. Het merendeel van de populatie wordt buiten de reservaten gevonden in eerder antropogene milieus. Op de golf bevindt zich de belangrijkste populatie van de hele kust en daarmee is dit wellicht het meest belangrijke gebied voor de soort in Vlaanderen, en bij uitbreiding België. Ruwe klaver groeit op de golf zowel in de schrale roughs, semi-roughs al fairways. In vergelijking met de vroegere karteringen van 2003 en 2010 is de soort spectaculair uitgebreid (van 71 naar 280 hokken van $25 \times 25 \mathrm{~m}^{2}$ ). Deze toename heeft zich vooral op de holes zelf voorgedaan.
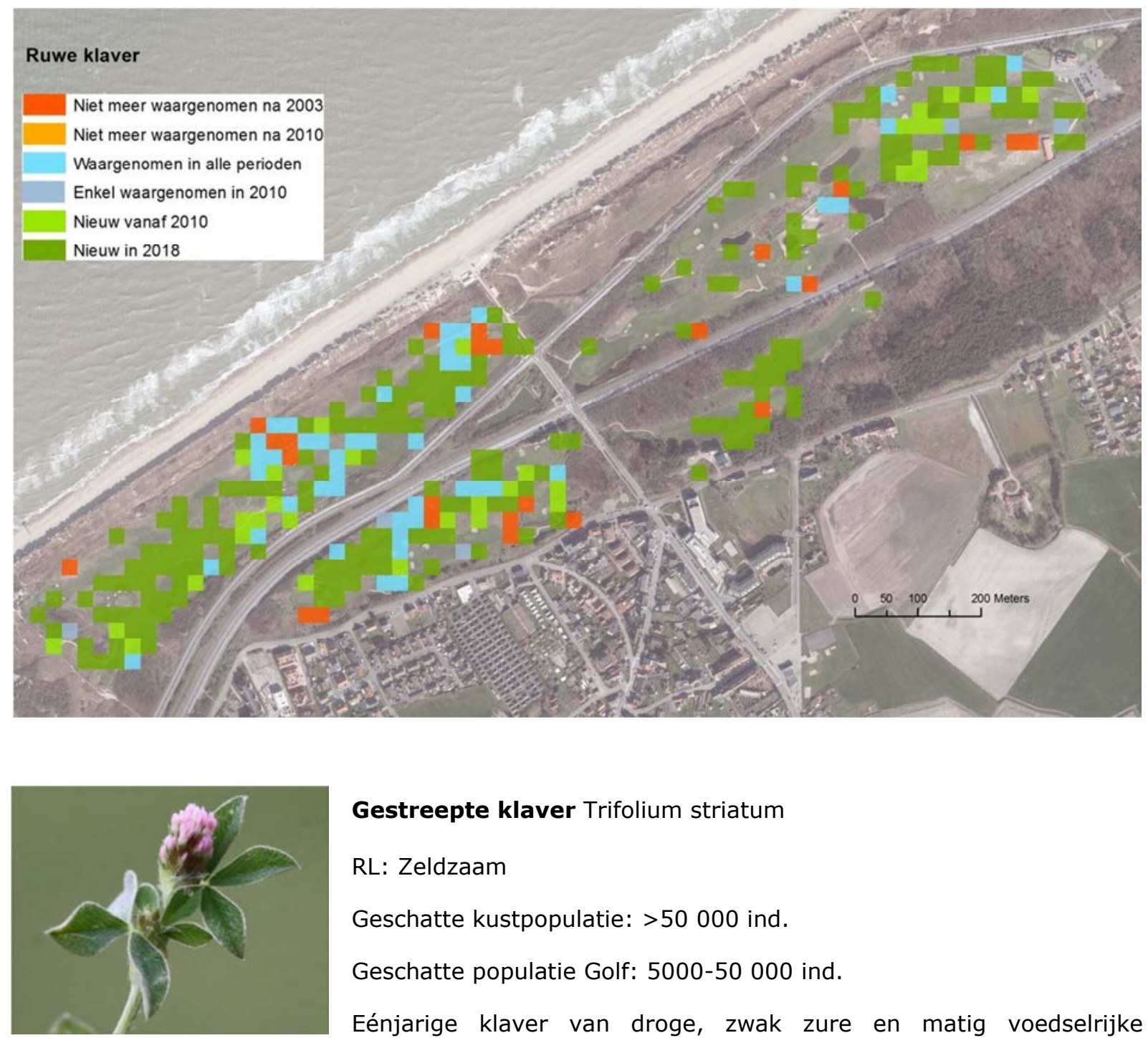

Gestreepte klaver Trifolium striatum

RL: Zeldzaam

Geschatte kustpopulatie: >50 000 ind.

Geschatte populatie Golf: 5000-50 000 ind.

Eénjarige klaver van droge, zwak zure en matig voedselrijke 
graslanden. In Vlaanderen grotendeels beperkt tot de kust. Evenals onderaardse klaver een soort van de 'klavergraslanden' van vooral D'Heye (goed voor ca. drie kwart van de populatie), de Schuddebeurze en de ontkalkte duingebieden in De Panne. Ook op de golfterreinen doet de soort het goed. Gestreepte klaver wordt niet vermeld door Verboven (1980), maar het is onwaarschijnlijk dat de soort toen ontbrak in de golf. Het kan wél wijzen op de relatieve zeldzaamheid ten opzichte van ruwe klaver, wat actueel niet meer uitgesproken is. Evenals ruwe klaver vertoont gestreepte klaver een spectaculaire uitbreiding van 24 hokken in 2003 naar 171 hokken in 2018. Op de golf vinden we beide soorten klavers in dezelfde vegetatie. Gestreepte klaver lijkt een iets grotere voorkeur te hebben voor duingrasland terwijl ruwe klaver relatief meer in de grazige vegetatie te vinden is (figuur 3.3).

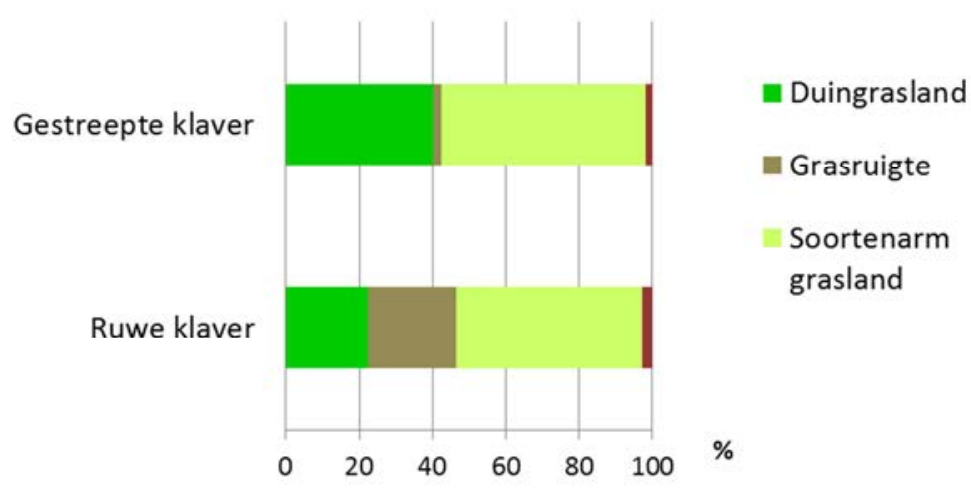

Figuur 3.3. Verschillen in habitatvoorkeur tussen ruwe en gestreepte klaver.

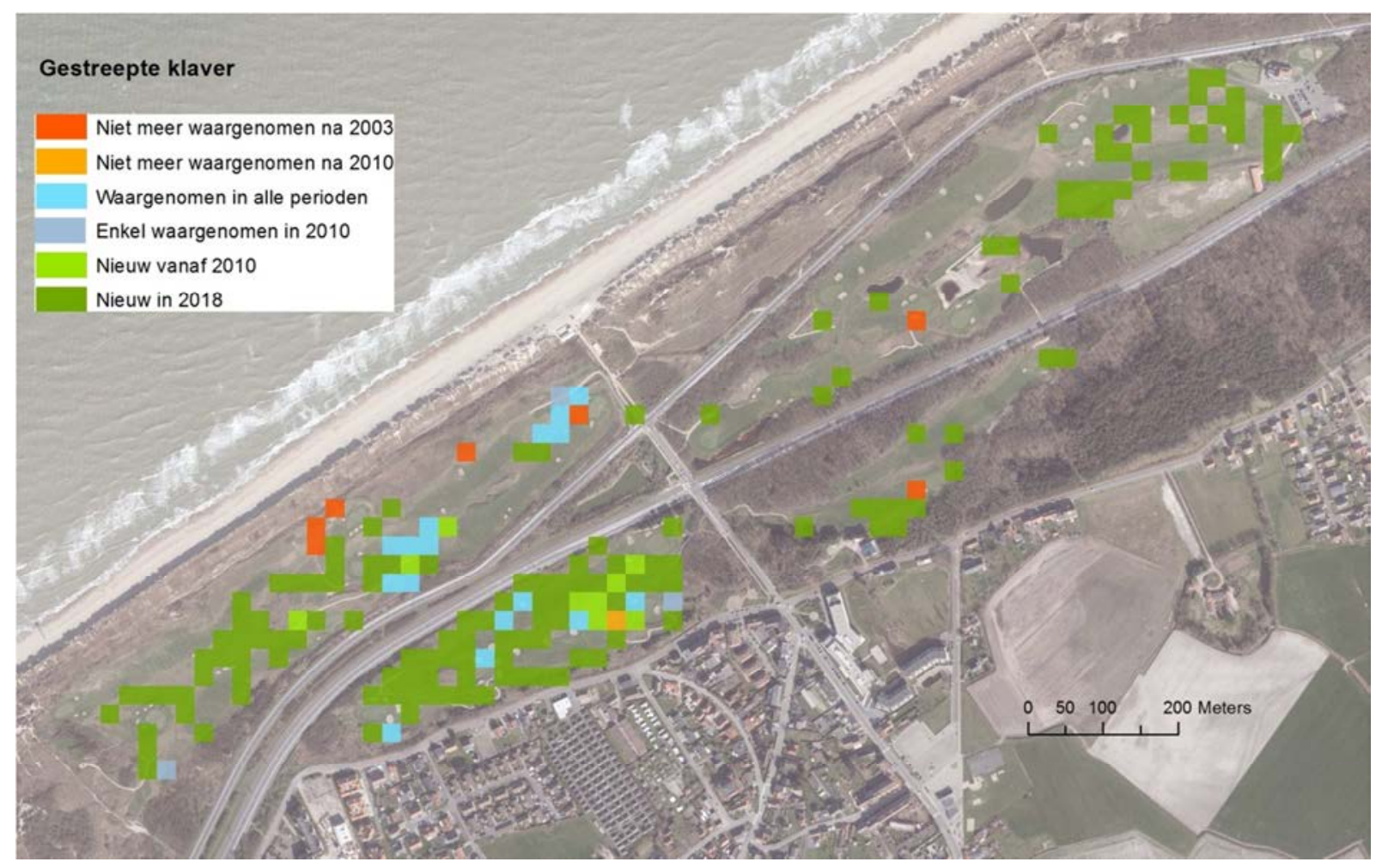




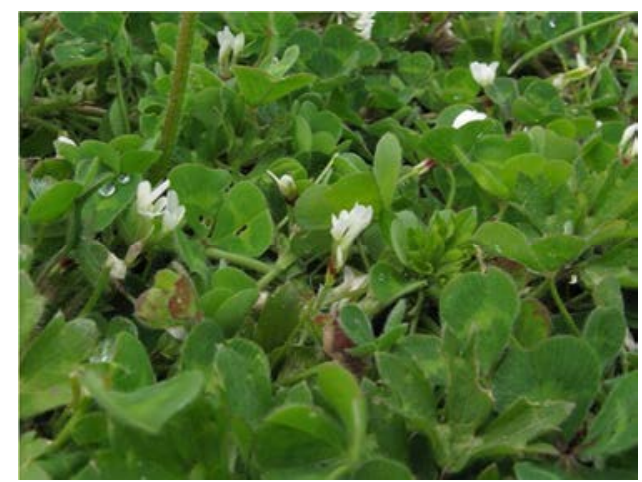

\section{Onderaardse klaver Trifolium subterraneum}

\section{RL: Zeldzaam}

Geschatte kustpopulatie: 5000-50 000 ind.

Geschatte populatie Golf: 5-25 ind.

Een derde typische vertegenwoordiger van de 'klavertjesgraslanden' (cf. draadklaver en gestreepte klaver). In Vlaanderen bekend van de kust maar ook van zandige terreinen met een lichte kalkaanrijking rond het Brugse. Ongeveer $90 \%$ van de kustpopulatie concentreert zich in D'Heye. Daarnaast zijn er ook behoorlijke deelpopulaties in de ontkalkte duingebieden in De Panne en Westende en duikt de verspreid aan de kust op in wegbermen, tuinen of andere antropogene milieus zoals campings (Verloove 2016).

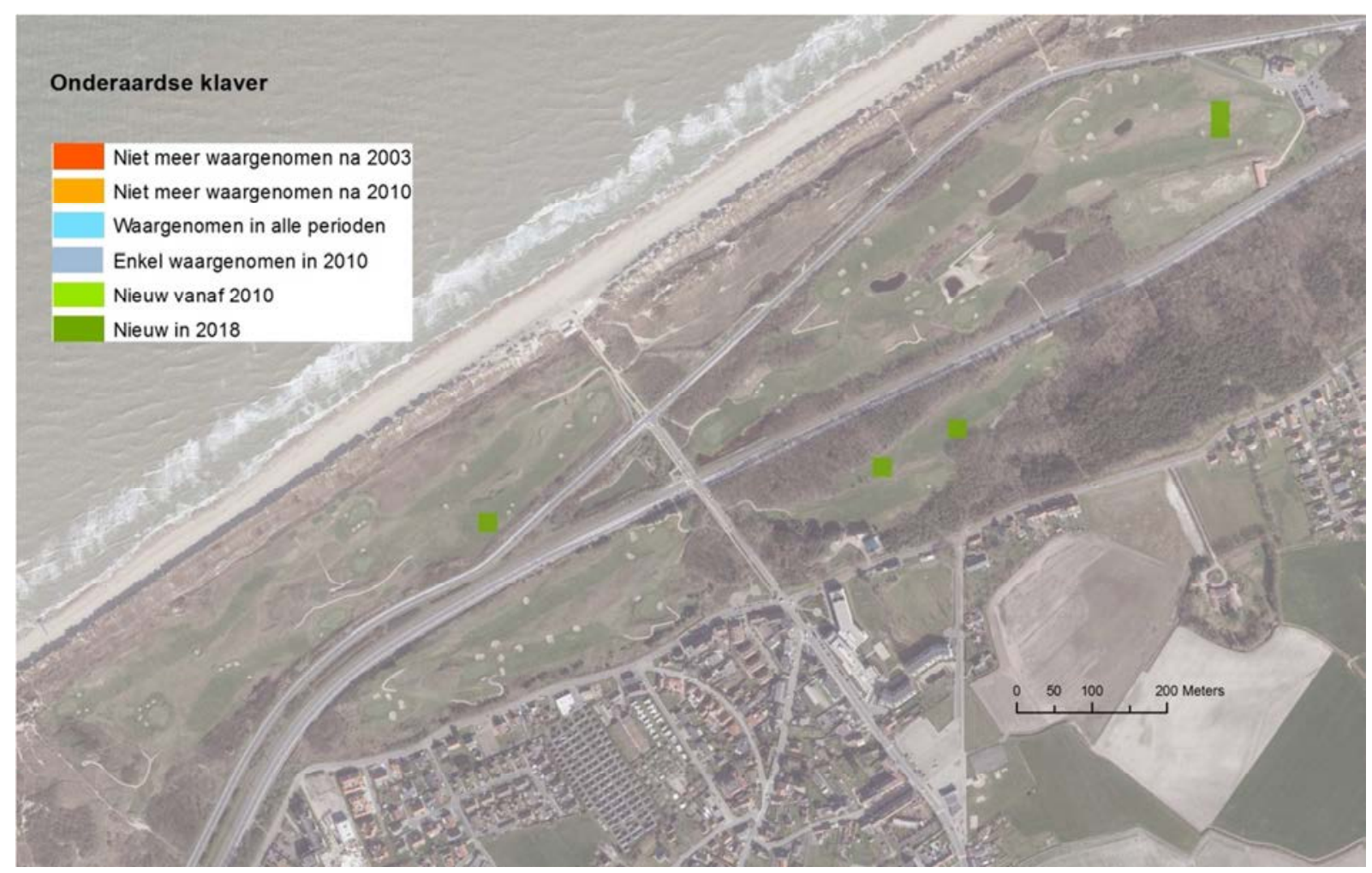




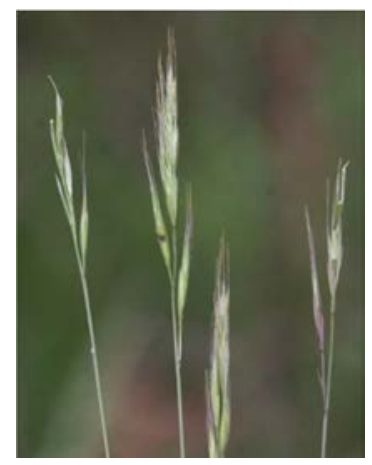

\section{Eekhoorngras Vulpia bromoides}

RL: Momenteel niet bedreigd

Geschatte kustpopulatie: >50 000 ind.

Geschatte populatie Golf: -

Eénjarige soort van open graslanden en andere pioniersmilieus. Aan de kust is de soort grotendeels beperkt tot de ontkalkte duinen van Cabour en D'Heye, maar in het binnenland groeit ze ook op meer kalkrijke standplaatsen. Verboven (1980) vond de soort in een van zijn opnames, namelijk $\mathrm{nr}$ 83 , ten zuiden van hole 18 . Recent niet meer teruggevonden.

\subsubsection{Floristische trends}

Globaal is het aantal aandachtssoorten op het golfterrein toegenomen van 33 in 2003 (29 in 2010) naar 44 tijdens de laatste inventarisatieronde in 2018.

\section{Vochtige duinvalleien}

De toename van het soortenaantal is in eerste instantie te danken aan de afbouw van de grondwaterwinning en de natuurontwikkelingsmaatregelen ter hoogte van hole 4 en ten noorden van hole 17. Daarbij verschenen 6 nieuwe soorten van natte duinvalleien en konden andere zich sterk uitbreiden. Natte duinmilieus worden relatief vlot gekoloniseerd door planten, enerzijds vanuit de zaadvoorraad in de bodem en anderzijds via stoffijne zaden die gemakkelijk door de wind worden verbreid. Typische soorten met langlevende zaden die ook op de golf minstens lokaal uit de bodemzaadvoorraad werden gerekruteerd zijn zeegroene zegge, drienervige zegge, borstelbies, dwergzegge, ruwe bies, strandduizendguldenkruid en sierlijke vetmuur. Met uitzondering van de eerste drie zijn het soorten die al gedurende langere periode niet meer op de golf waren waargenomen. De tweede groep duinvalleisoorten met stoffijne zaden omvat onder meer verschillende orchideeën. Zowel vleeskleurige orchis als rietorchis hebben de golf het voorbije decennium weten te koloniseren en vooral de populatie vleeskleurige orchis is ook al sterk uitgebreid. De snelle kolonisatie is waarschijnlijk ook gerelateerd aan de sterke uitbreiding van de populaties van verschillende orchideeënsoorten aan de kust tijden de voorbije decennia door gericht beheer en inrichting van terreinen (Leten et al. 2012). De grondwaterafhankelijke flora van de golf, die sterk was achteruitgegaan door waterwinning en kunstmatige inrichting van de oevers van open waters weet zich dus geleidelijk aan te herstellen. Zeer kritische duinvaleisoorten zoals duingentiaan en honingorchis zijn echter (nog?) niet terug opgedoken.

\section{Semi-rough en fairway}

Een tweede opvallende trend is de sterke uitbreiding van een aantal aandachtssoorten op de semirough en fairway, namelijk draadklaver, ruwe en gestreepte klaver en eenjarige hardbloem. Het gewijzigde beheer van deze zones met vooral een afbouw van de bewatering, is de meest voor de hand liggende verklaring voor deze trend. Hierdoor zijn deze zones verschraald en speelt droogtestress een toenemende rol in de vegetatieontwikkeling. Dit doorbreekt de grasdominantie waardoor eenjarigen, zoals de bovenvermelde aandachtssoorten er zich weer kunnen vestigen. Wellicht is hierdoor ook een uitbreiding van overblijvende duingraslandsoorten zoals geel walstro, kruipend stalkruid en gewone rolklaver mogelijk (figuren 3.4 en 3.5). Een aantal permanente 
vegetatieproefvlakken in deze zones zou het mogelijk maken om dit in de toekomst beter op te volgen.

\section{Duingraslanden in de roughs}

De ontwikkeling van droge duingraslanden verloopt in het algemeen veel langzamer dan bij de natte duinvalleien. Dit houdt in de eerste instantie verband met de droogtestress die processen zoals biomassaproductie en -afbraak of humusaccumulatie in de bodem sterk afremt. Hierdoor verloopt de ontwikkeling naar soortenrijke vegetaties zelf bij een optimaal beheer zeer langzaam. Een voordeel van de droogtestress is dat ook verruigingsprocessen langzamer verlopen dan in vochtige milieus. Hierdoor kunnen aandachtssoorten nog lang na-ijlen in de vegetatie, zelfs als een geschikt beheer ontbreekt. Verder hebben relatief veel aandachtssoorten van duingrasland relatief grote zaden met een relatief geringe levensduur (grote tijm, geel zonneroosje, nachtsilene, ...). Onder meer klavers en wondklaver vormen hierop een uitzondering.

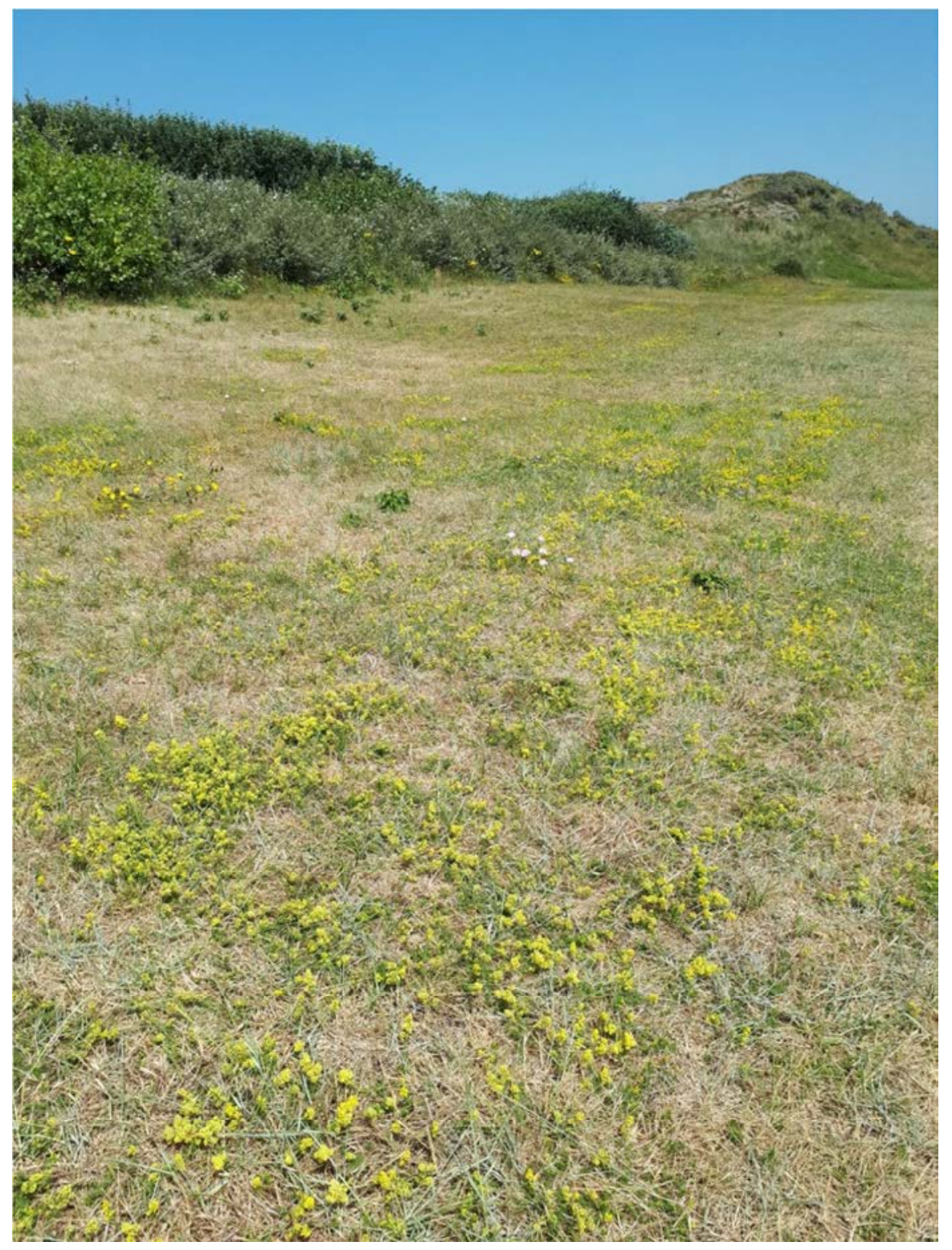

Figuur 3.4. Geel walstro in de semi-rough van hole 7. Wellicht doet deze soort het hier goed omwille van de afbouw van de beregening. 


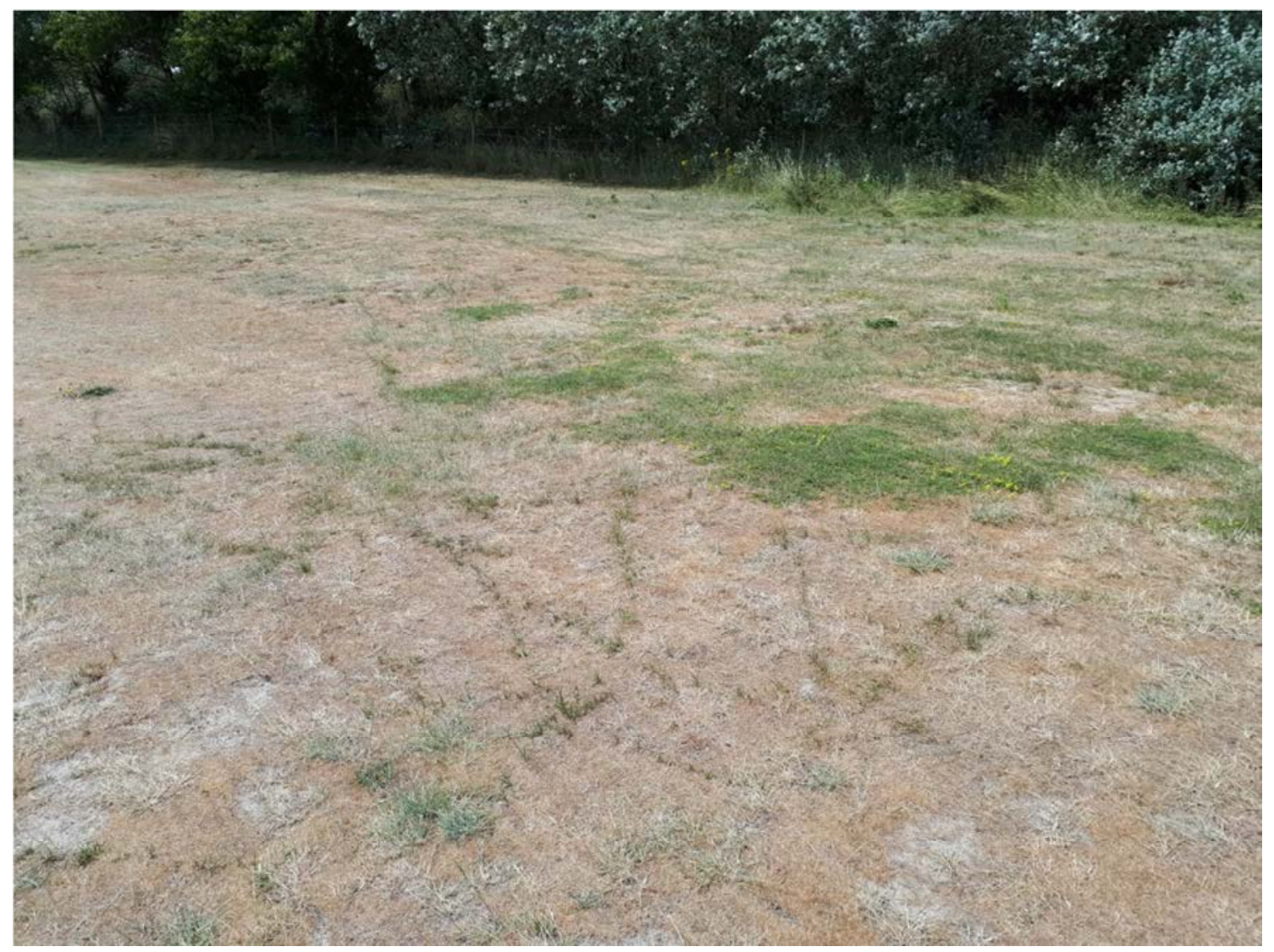

Figuur 3.5. In schrale en droge delen van de fairways en semi-roughs bepalen duingraslandsoorten de structuur van de vegetatie. Hier zien we het typische uitbreidingspatroon van zandzegge met nieuwe bladeren die op regelmatige afstand opduiken vanuit de lange wortelstokken.

Deze factoren verklaren mee waarom de duingraslanden in de roughs geen uitgesproken trend vertonen op het vlak van aandachtssoorten. Een aantal soorten waaronder cipreswolfsmelk en grote ratelaar vertoont een duidelijke uitbreiding. Cipreswolfsmelk gedijt zowel in kort schraal grasland als in ruigere vegetatie en kan er zich via wortelstokken sterk uitbreiden. Grote ratelaar vertoont een opmars aan de hele kust door uitbreiding van het natuurtechnisch maaibeheer en profiteert ook op de golf duidelijk van een geschikt maaibeheer van de roughs. Deze trend is duidelijkst in de rough ten noorden van hole 7. Gewone agrimonie, beemdkroon en walstrobremraap lijken er licht op vooruit te gaan maar de oorzaak hiervan is niet duidelijk. Bevertjes en gewone bermzegge werden enkel in de recente karteerperiode aangetroffen. Zeker bevertjes werd hoogstwaarschijnlijk tijdens de vorige karteerrondes over het hoofd gezien. De soort wordt al vermeld door Verboven (1980, opname 16), beschikt niet over een langlevende zaadvoorraad en staat niet bekend als een vlotte verbreider. Ook het ontbreken van tandjesgras in de eerste karteerperiode is vermoedelijk te wijten aan de kartering en niet aan effectieve trends. Verboven (1980) vond de soort 'abundant rond 2 pannetjes'.

Soorten met een min of meer stabiele populatie zijn bokkenorchis, wondklaver en grote tijm. De verspreiding van bokkenorchis lijkt sterke fluctuaties te vertonen. De soort gaat achteruit in de oostelijke terreindelen maar nam sterk toe in het noordwesten, ten noorden van hole 7 . Verboven (1980) beschrijft de verspreiding als 'erg abundant in de Heuveltjes' (ZW), een paar exemplaren in de Bosjes (ZO) en één exemplaar in de Jasmientjes (NO) en Zeetje (NW)'. Zowel van wondklaver als grote tijm is het aantal groeiplaatsen globaal achteruitgegaan maar lijkt de populatie goed stand te houden of zelfs uit te breiden op de overgebleven locaties. Bij grote tijm is die 
achteruitgang substantieel ten zuiden van hole 15, waar de soort lokaal volledige verdwenen is. Deze trend is indicatief voor de verdere achteruitgang van de habitatkwaliteit op de onbeheerde terreindelen door verruiging, vergrassing en verstruweling (figuur 3.6). Wellicht is deze trend nefast geweest voor nachtsilene, een soort die in de recente kartering niet meer teruggevonden is. Het verdwijnen van deze soort op de golf heeft een grote impact op de verspreiding van deze soort aan de kust, die daardoor een leemte vertoont tussen de Warandeduinen in Middelkerke en Park 58 in Knokke. Ook ogentroost (Euphrasia spec.) en geelhartje, twee soorten van vochtige graslanden, zijn vermoedelijk door lokale verruiging en verstruweling uit het gebied verdwenen. Ogentroost werd door Verboven (1980) in 3 opnames aangetroffen, geelhartje in 11. Geel zonneroosje en kleine pimpernel zijn momenteel bijzonder kwetsbaar omwille van de zeer beperkte omvang van de populatie. Zonder bijkomende beheermaatregelen is de kans groot dat ook deze soorten uit het gebied verdwijnen.
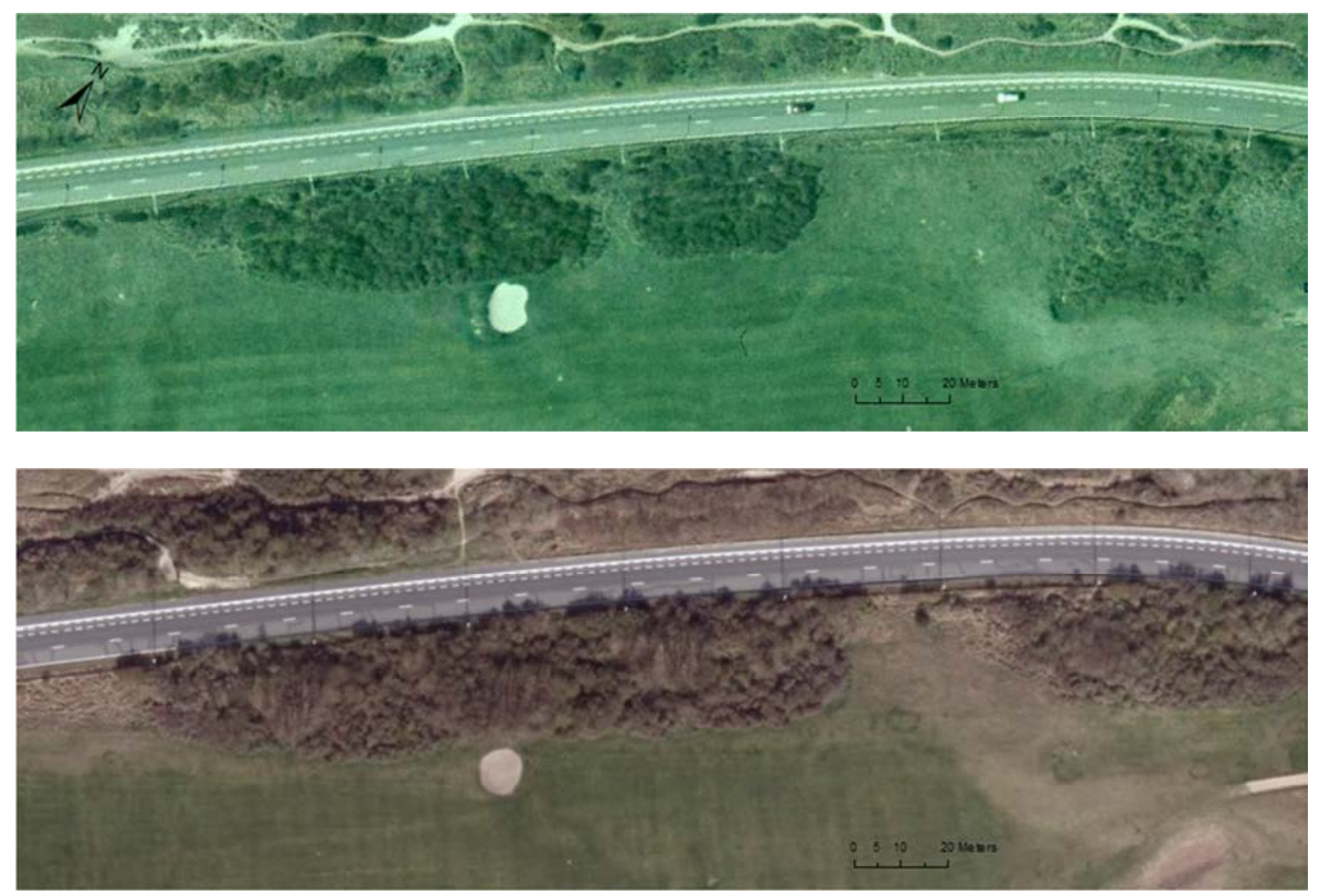

Figuur 3.6. Uitbreiding van struweel in de rough ten noorden van hole 2. Boven: 2000; onder: 2017.

Verschillende andere factoren bepalen mee de waargenomen trends in verspreiding en populatiegroottte van de flora van de golf. Waarnemerseffecten zijn zeker aanwezig, getuige het ontbreken van waarnemingen van grote op het Spanjaardduin (zie hoger), maar niet systematisch te traceren. Voor heel kleine soorten zoals dwergvlas, -bloem en -gras speelt de ervaring en het scherpe oog van de karteerder een rol. Mogelijk is daarom ook een soort als eekhoorngras niet meer op de golf waargenomen (door Verboven in één van de opnames aangetroffen in 1980). Ook weerseffecten bepalen de herkenbaarheid van bepaalde soorten. Zo was 2018 een bijzonder warm en droog jaar waardoor eenjarigen sneller waren uitgebloeid en minder snel tot kieming kwamen.

Een laatste factor die trends in de verspreiding van soorten in toenemende mate bepaalt is de klimaatwijziging. Zo is de algemene uitbreiding van onder meer laksteeltje, zeekool, bokkenorchis en kleine rupsklaver aan onze kust hoogstwaarschijnlijk (mee) aan de opwarming van het klimaat te wijten. 


\subsection{Vegetatiekaart}

Aan de opmaak van de vegetatiekaart werden 6 karteerdagen besteed tijdens de maanden augustus en september. De kaart omvat 1134 polygonen. In de attributentabel zit zowel informatie over de verschillende delen van de holes (figuur 3.7) als over de vegetatie (figuur 3.8) vervat. Tabel 3.3 geeft een overzicht van de oppervlakte van de combinatie van beide types.

Soortenarme graslanden, inclusief de bespeelde delen van de golf, vormen het belangrijkste vegetatietype van het terrein $(47,5 \%)$. Bos en struweel bedekken ongeveer $25 \%$ van de oppervlakte. Ruigten gedomineerd door grassen, dauwbraam of in mindere mate ruigtkruiden bedekken $11 \%$ van het terrein evenals de meer soortenrijkere open vegetaties (duingrasland, duinvalleivegetatie, mosduin, ...). De holes en de hardere infrastructuur van de golf nemen samen een kleine helft van de oppervlakte in beslag.

Tabel 3.3. Oppervlaktes van de verschillende vegetatietypen in de golf.

\begin{tabular}{|c|c|c|c|c|c|c|c|c|c|c|c|c|c|c|}
\hline & Geen golf & $\begin{array}{l}3 \\
0 \\
0 \\
0 \\
0\end{array}$ & $\begin{array}{l}\frac{0}{0} \\
\frac{0}{00} \\
\frac{5}{0} \\
\frac{2}{10} \\
\frac{10}{1}\end{array}$ & 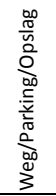 & \% & 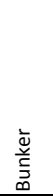 & $\begin{array}{l}\mathbb{\Xi} \\
\stackrel{\Xi}{0} \\
\end{array}$ & 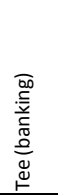 & 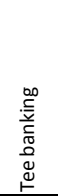 & 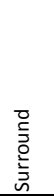 & 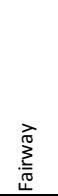 & 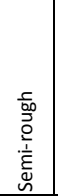 & TOTAAL & $\%$ \\
\hline Helmduin & 0,20 & & & & & & & & & & & & 0,20 & 0,4 \\
\hline Mosduin & 0,23 & & & & & & & & & & & 0,02 & 0,25 & 0,5 \\
\hline Duingrasland & 3,65 & & & & 0,07 & & & & 0,06 & & & 0,68 & 4,47 & 8,8 \\
\hline Grasruigte & 4,08 & & & & & & & & & & & 0,02 & 4,10 & 8,1 \\
\hline Dauwbraam & 1,32 & & & & & & & & & & & & 1,32 & 2,6 \\
\hline Ruigte & 0,34 & & & & & & & & & & & & 0,34 & 0,7 \\
\hline Soortenarm grasland & 2,10 & & & & 0,97 & & & & 0,42 & 1,96 & 7,76 & 8,72 & 21,92 & 43,2 \\
\hline Duinvallei & 0,20 & & & & & & & & & & & & 0,20 & 0,4 \\
\hline Water/Oever & 0,79 & & & & & & & & & & & & 0,79 & 1,6 \\
\hline Kruipwilg & 0,06 & & & & & & & & & & & & 0,06 & 0,1 \\
\hline Struweel & 2,22 & & & & & & & & & & & & 2,22 & 4,4 \\
\hline Exotenstruweel & 0,92 & & & & & & & & & & & & 0,92 & 1,8 \\
\hline Loofbos & 7,91 & & & & & & & & & & & & 7,91 & 15,6 \\
\hline Struweel/Bos & 1,77 & & & & & & & & & & & & 1,77 & 3,5 \\
\hline Naaldbos & 0,51 & & & & & & & & & & & & 0,51 & 1,0 \\
\hline Golf & & & & & & 0,39 & 0,99 & 0,86 & 0,03 & & & & 2,26 & 4,4 \\
\hline Antropogeen & & 0,17 & 0,62 & 0,67 & & & & & & & & & 1,46 & 2,9 \\
\hline TOTAAL & 26,32 & 0,17 & 0,62 & 0,67 & 1,04 & 0,39 & 0,99 & 0,86 & 0,51 & 1,96 & 7,76 & 9,44 & 50,72 & \\
\hline$\%$ & 51,9 & 0,3 & 1,2 & 1,3 & 2,0 & 0,8 & 1,9 & 1,7 & 1,0 & 3,9 & 15,3 & 18,6 & & \\
\hline
\end{tabular}

Figuur 3.9. geeft de vegetatiekaart weer volgens een legende die de nadruk legt op de verschillende graslandtypen. Op deze kaart is ook de verspreiding van de kenmerkende duingraslandsoorten weergegeven. De floristische informatie wordt samengevat weergegeven in figuur 3.10 die de Shannon-Wiener diversiteitsindex van de waargenomen graslandsoorten weergeeft binnen de $25 \times 25 \mathrm{~m}^{2}$ rastercellen. In het terrein zijn duidelijke concentraties van soortenrijke graslanden aanwezig:

- $\quad$ tussen holes 1 en 18

- $\quad$ ten zuiden van hole 15

- $\quad$ het gehele zuidwestelijke deelgebied rond holes 12 en 14

- de zone tussen holes 9 en 10

- de meest zeewaartse strook ten noorden van holes 5 en 7

- de flank van het Spanjaardduin ten westen van holes 8 en 9. 

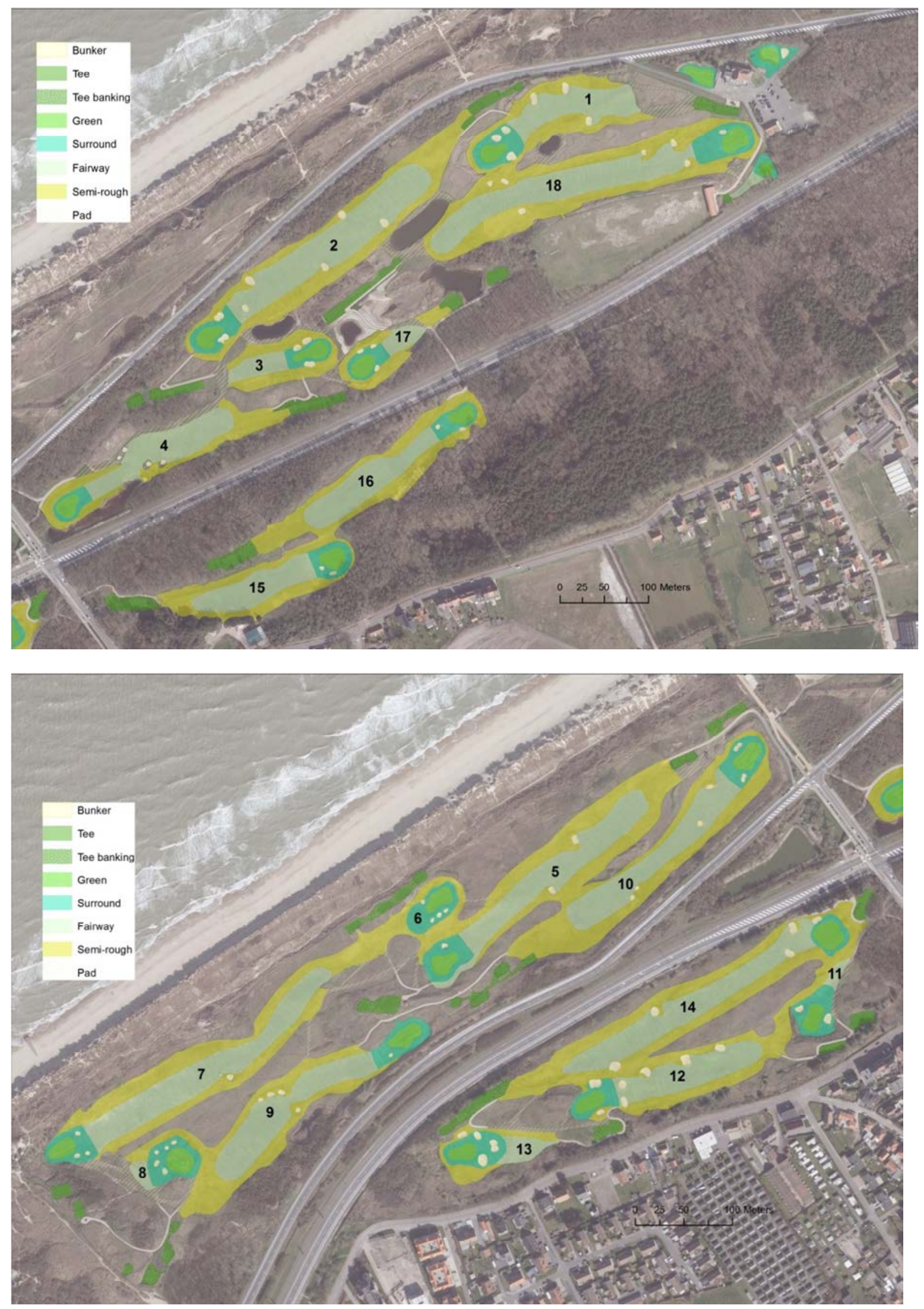

Figuur 3.7. Overzicht van de 18 holes op de golf van De Haan. 

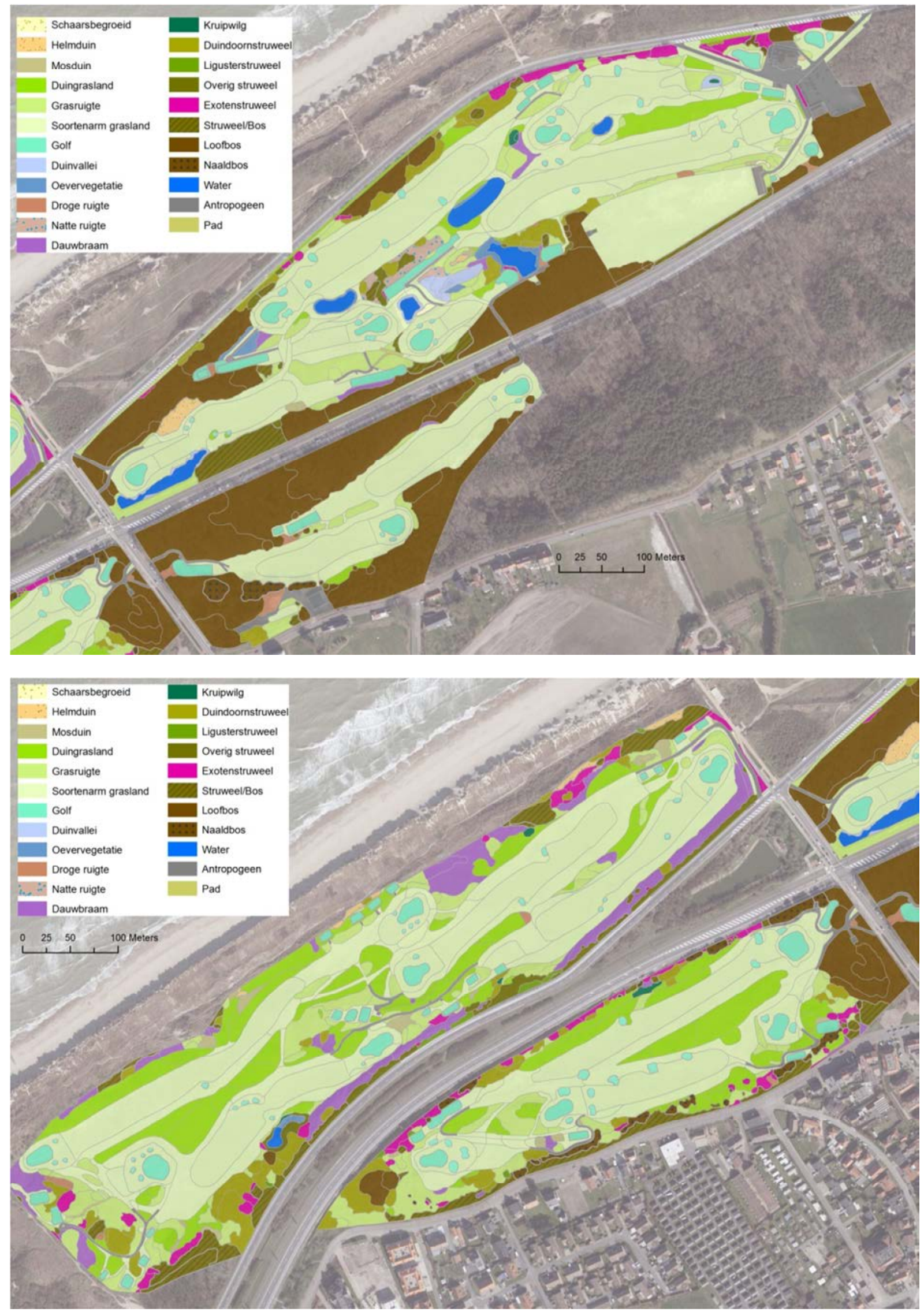

Figuur 3.8. Vegetatiekaart van de golf. 

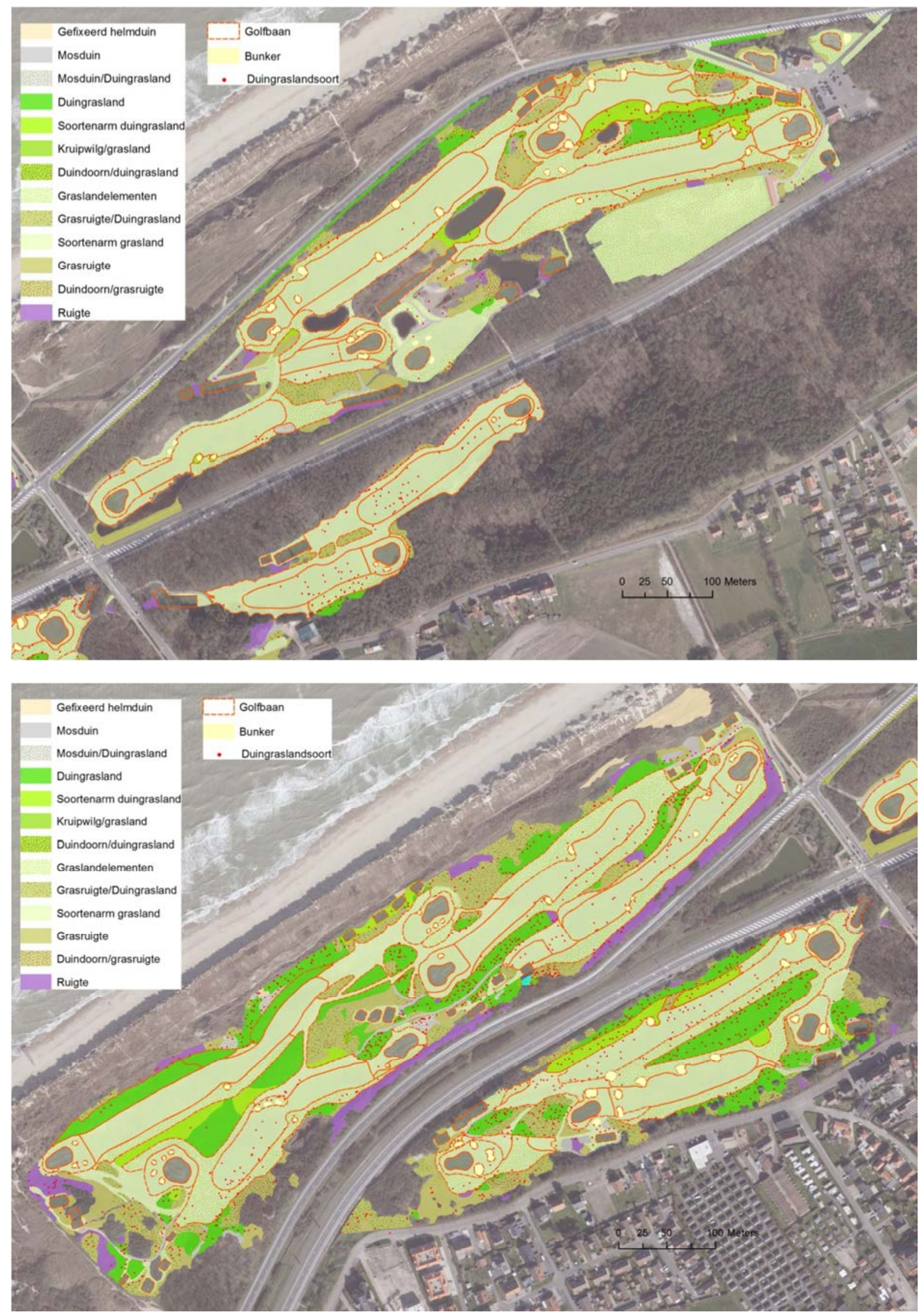

Figuur 3.9. Vegetatiekaart van de golf met nadruk op de verschillende graslandtypen. 


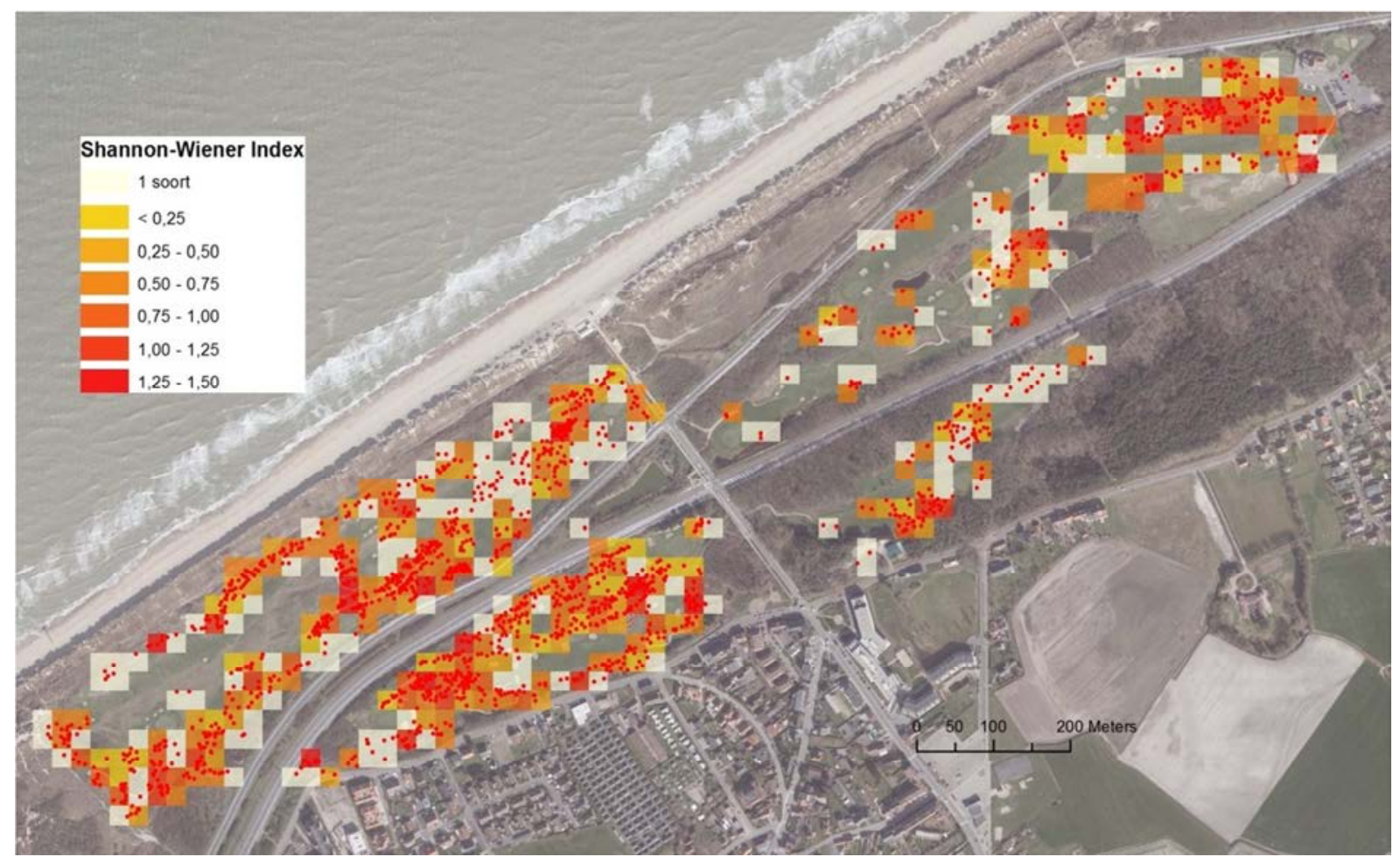

Figuur 3.10. Shannon-Wiener diversiteitsindex voor duingraslandsoorten per $25 \times 25 \mathrm{~m}^{2}$ hok.

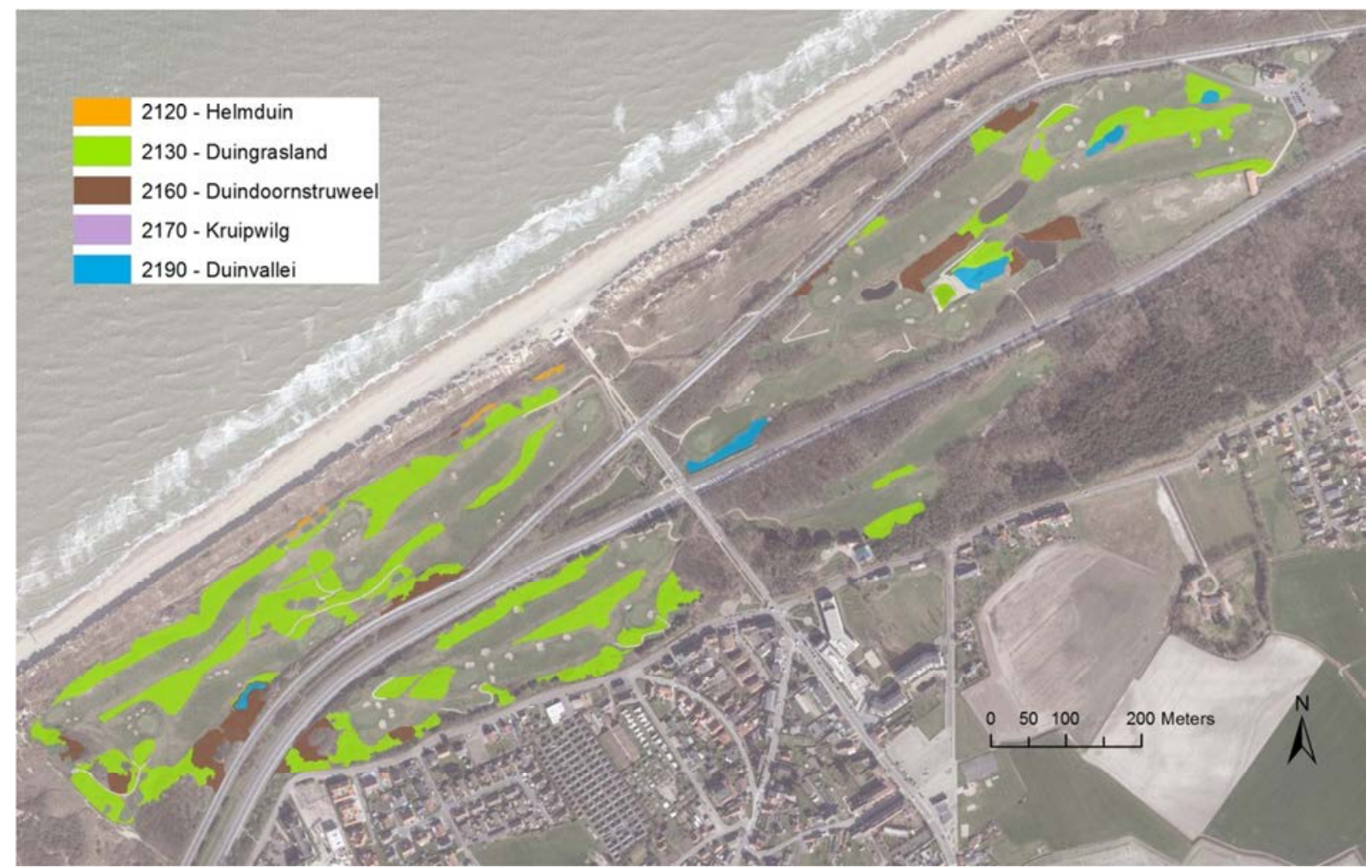

Figuur 3.11. Natura 2000 habitattypes op het golfterrein. 
In figuur 3.11 wordt de vegetatiekaart vertaalt naar de habitattypes gebruikt in de Europese Habitatrichtlijn. Tabel 3.4 geeft de oppervlaktes van de verschillende types weer. Duingraslanden en mosduinen, habitattype 2130 is het belangrijkste type binnen het terrein ( 8.22 ha). Ook duinstruwelen ( $2160-1,58 \mathrm{ha})$ en duinvalleivegetaties $(2190-0,95 \mathrm{ha})$ zijn relatief goed vertegenwoordigd. Helmduinen (2120) en kruipwilgvegetaties (2170) nemen slechts een heel beperkte oppervlakte in. De recent bepaalde oppervlaktes verschillen substantieel van de cijfers die door het beleid worden gebruikt en die gebaseerd zijn op de BWK kartering uit 2003. Vooreerst ligt de oppervlakte duingraslanden actueel veel lager. Dit heeft te maken met de veel ruwere manier van karteren in de BWK, waarbij alle graslandtypes op de golf, inclusief fairways en andere intensief bespeelde, soortenarme graslanden mee opgenomen zijn in de habitatvlekken. Een tweede negatieve trend is de afname van de oppervlakte helmduin. Ook hier speelt de karteermethode parten maar hier is ook sprake van een reële trend, namelijk de fixatie van helmduin en spontane successie naar mosduin. De afname van de oppervlakte duinstruweel heeft vooral te maken met uitbreiding van bomen (abelen en esdoorn).

De toename van de oppervlakte duinvalleihabitats is enerzijds te danken aan de natuurontwikkelingsmaatregelen ter hoogte van hole 4 en ten noorden van hole 17 en anderzijds aan het herstel van de bestaande depressies door afbouw van waterwinning en aangepast beheer. Tot slot duiden we bij de recente kartering ook een kleine vlek kruipwilgstruweel aan. Gezien de geringe oppervlkate $\left(180 \mathrm{~m}^{2}\right)$ werd deze vlek in de BWK kartering niet meegenomen maar gezien de zeldzaamheid van het type is een vermelding hier toch belangrijk.

Tabel 3.4. Oppervlakte (ha) van de verschillende EU-habitattypes in de golf.

\begin{tabular}{|l|c|c|}
\hline & Kartering 2018 & BWK (2003) \\
\hline 2120 Helmduinen & 0,08 & 1,07 \\
2130 Duingrasland & 8,22 & 32,44 \\
2160 Duindoornstruweel & 1,58 & 2,45 \\
2170 Kruipwilg & 0,02 & \\
2190 Duinvallei & 0,95 & 0,50 \\
Geen Habitat & 39,65 & 14,04 \\
\hline TOTAAL & $\mathbf{5 0 , 5 0}$ & $\mathbf{5 0 , 5 0}$ \\
\hline
\end{tabular}

\subsection{Uitheemse planten}

Op de golf van De Haan zijn substantiële oppervlaktes beplant met niet inheemse struiken en bomen (figuur 3.11, tabel 3.5). Uitheemse soorten zijn evolutionair niet aangepast aan het lokale ecosysteem en spelen daarom hoogstens een beperkte rol binnen de complexe trofische of andere ecologische netwerken. Soms is er ook sprake van een duidelijk negatieve impact op het ecosysteem. Niet inheemse soorten kunnen zich bijvoorbeeld door gebrek aan natuurlijke vijanden invasief gedragen of als waardplant een ecologische sink vormen. Gezien lang niet alle relaties in ecosystemen bekend zijn, is een voorzorgsbeginsel aangewezen waarbij alle uitheemse soorten in principe ongewenst zijn in de natuur. Dit betekent uiteraard niet dat het ook effectief haalbaar is om ze ook allemaal uit de natuurgebieden te verwijderen.

Abelen en populieren maken het grootste deel van de oppervlakte uit (ca. 80\%). Samen met gewone esdoorn bepalen zij grotendeels de structuur van de loofbossen op het terrein. Het is daarom niet wenselijk om alle abelen en populieren te kappen. Voor de dergelijke bossen wordt eerder een geleidelijke omvorming voorgesteld door zeer lokaal kappen of ringen en aanplant van ontbrekende boomsoorten als (fladder)iep, winterlinde of zoete kers. 
Over het statuut van gewone esdoorn bestaat discussie. De soort is inheems in het zuiden van België maar het is onduidelijk wat de natuurlijke verspreiding in Vlaanderen zou zijn zonder menselijke tussenkomst. Los van deze discussie breidt de soort zich heel snel uit, zowel in bossen als in duingrasland en worden esdoorns in verschillende duingebieden actief in toom gehouden. Voor de golf van De Haan is het wenselijk de verspreiding van de soort tot de bossen te beperken.

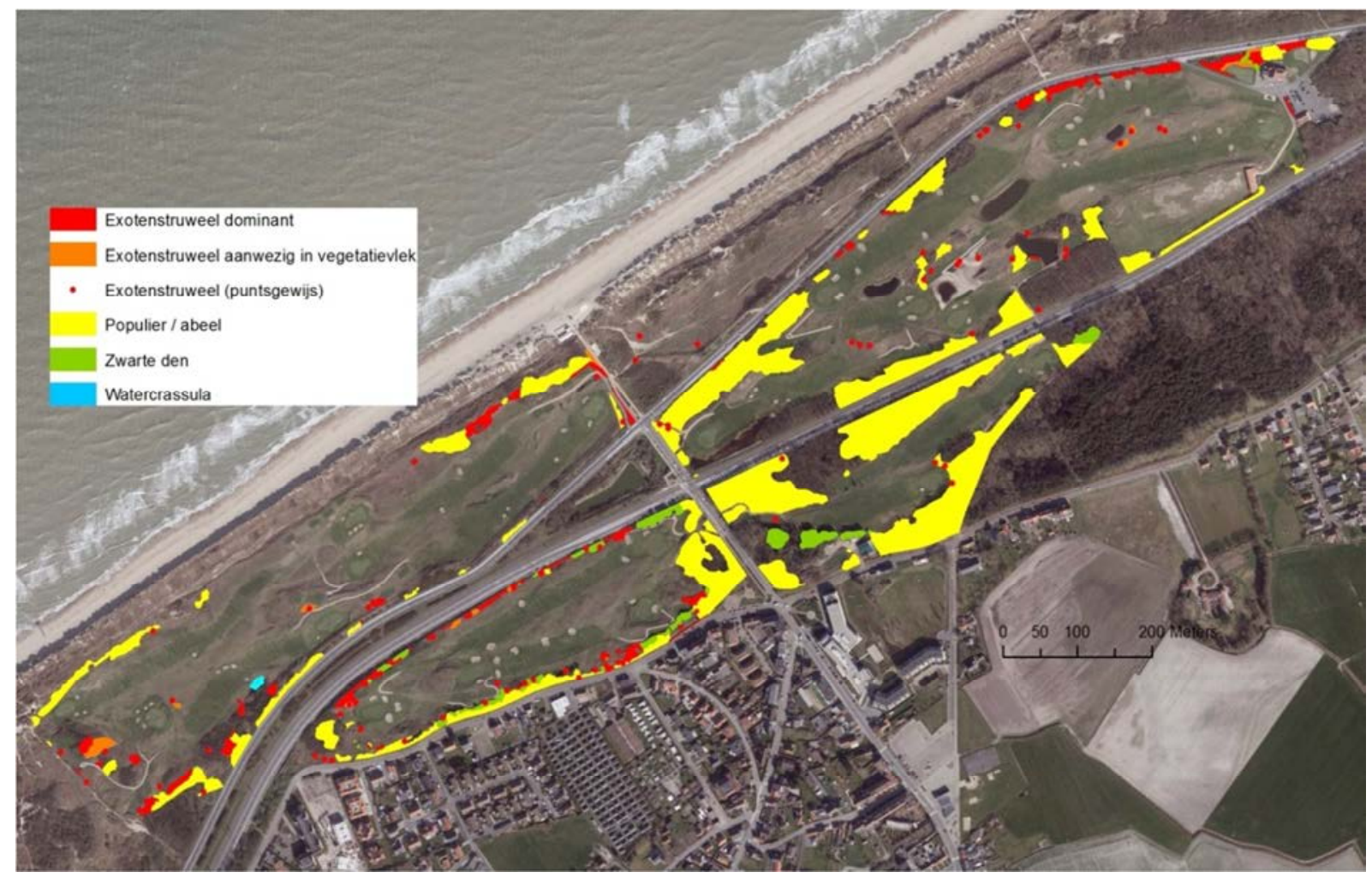

Figuur 3.11. Verspreiding van niet inheemse plantensoorten op de golf.
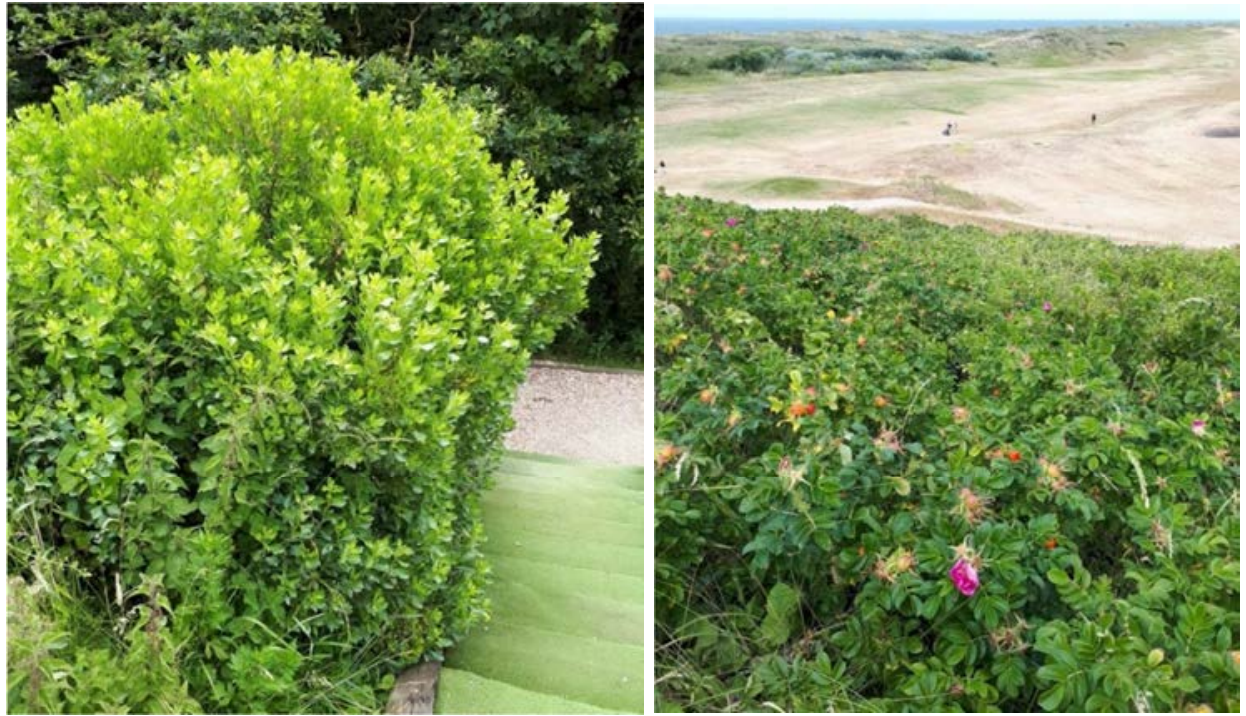

Figuur 3.12. Struikaster (links) en rimpelroos (rechts); twee invasieve uitheemse struiksoorten die prioritair moeten aangepakt worden. 


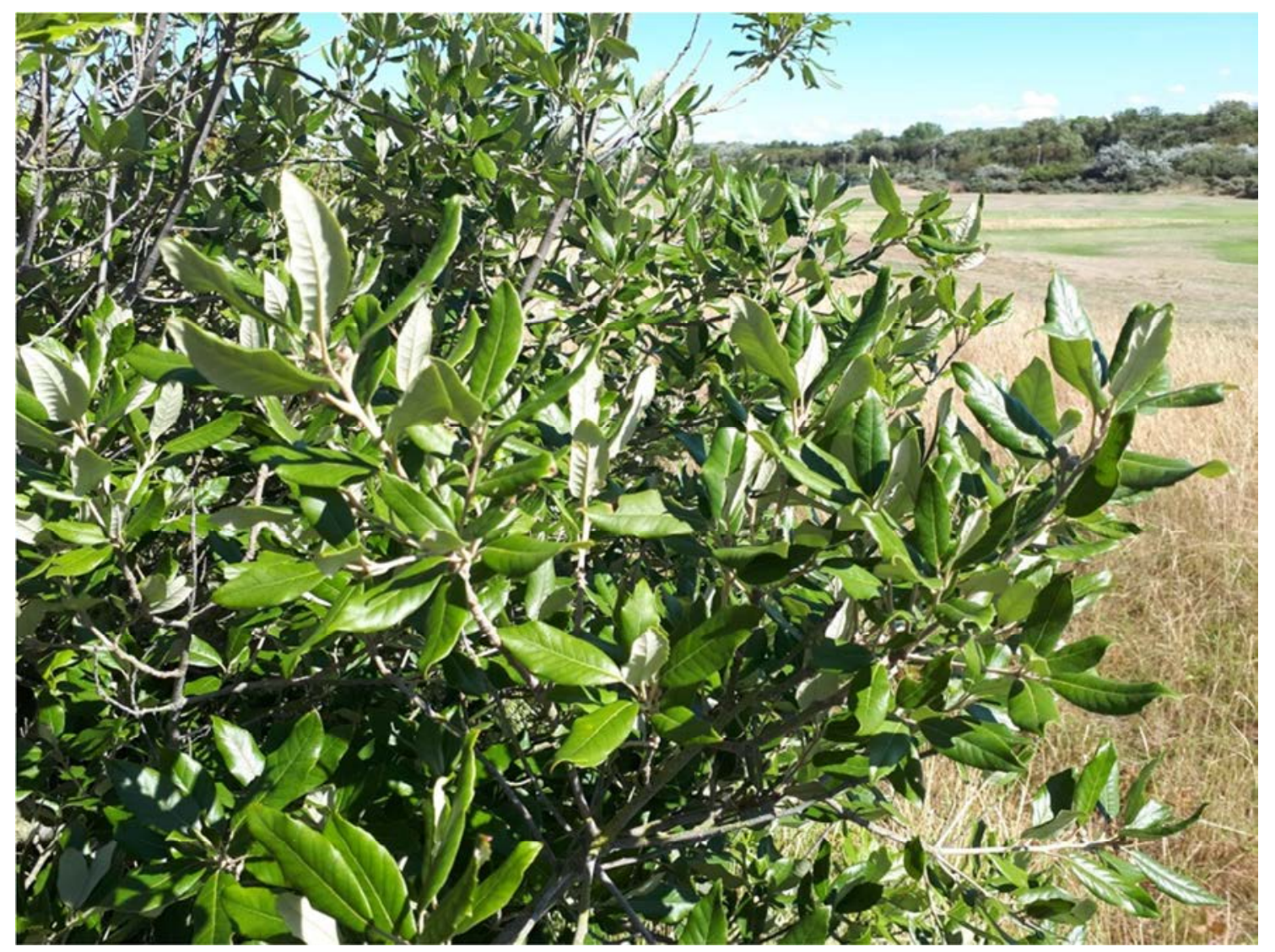

Figuur 3.13. Een breedbladige olijfwilg (Eleagnus cf. ebbingei) werd verspreid over het terrein aangeplant.

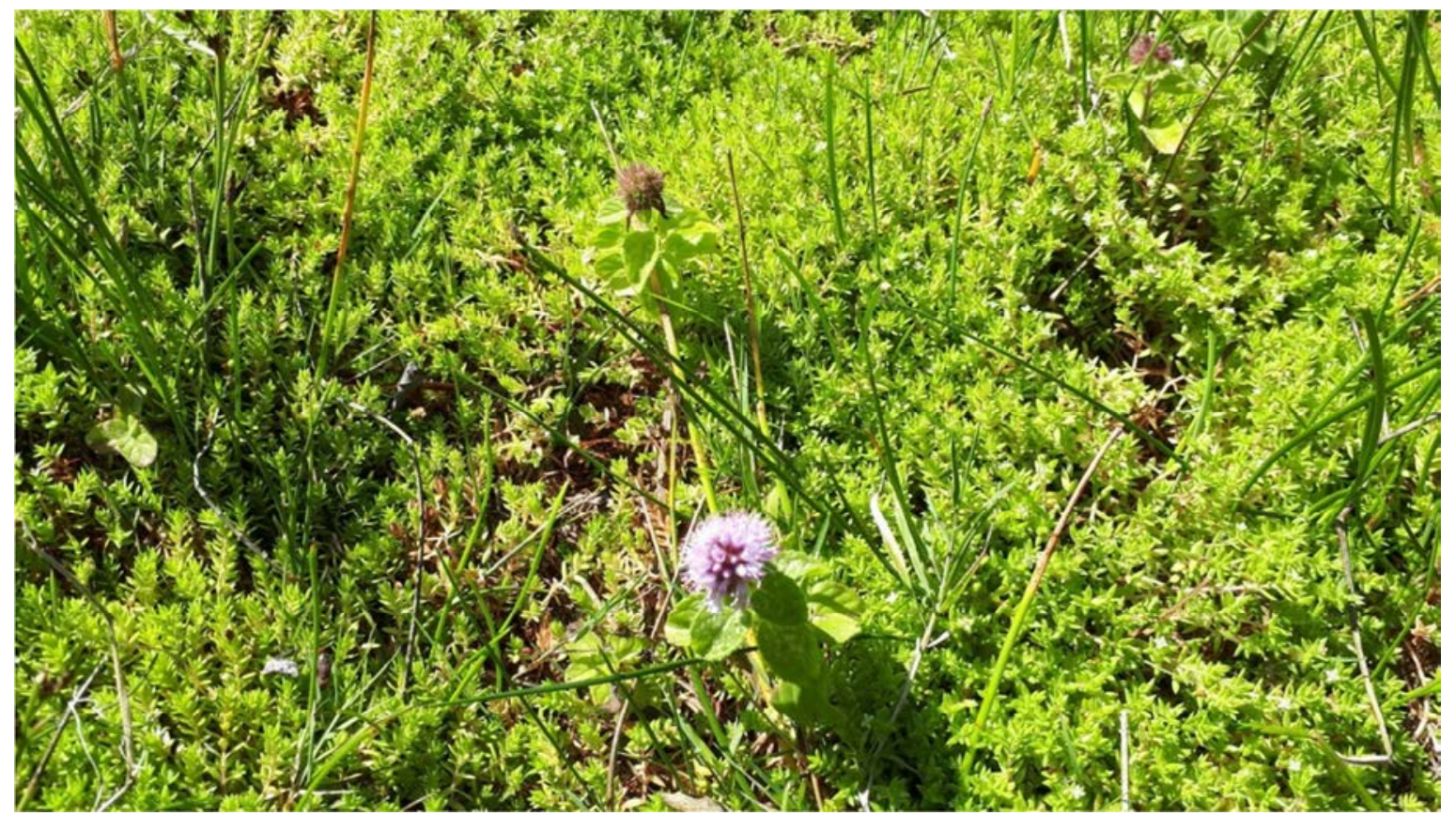

Figuur 3.14. Watercrassula breidt zich zeer snel uit in vochtige duinvalleien en verdringt nagenoeg alle kruidachtige vegetatie. 
Het meest problematisch zijn de invasieve struweelsoorten die door vegetatieve uitbreiding of verspreiding via zaden inheemse, ecologisch waardevolle habitattypen verdringen. Op de golf zijn dat vooral rimpelroos, Amerikaanse vogelkers en in mindere struikaster. Deze laatste soort is relatief zouttolerant en vormt vooral een (potentieel) probleem in de (hoge) schorrengebieden zoals de Baai van Heist of het Zwin. Het is wenselijk om deze soorten op korte termijn geheel te verwijderen. Ook de invasieve klimop (vermoedelijk Hedera hibernica), onder meer ten noorden van hole 5 en ten zuiden van hole 15 wordt best zo snel mogelijk verwijderd. Overige struweelsoorten breiden zich niet of minder snel uit en vormen een minder grote prioriteit. Toch is het wenselijk om ook die soorten op termijn volledig uit het gebied te verwijderen.

Bijzonder problematisch is het vetplantje watercrassula (Crassula helmsii), dat zich recent in de poel en depressie ten zuiden van hole 9 heeft gevestigd. Deze soort kan zich heel snel uitbreiden en verdringt nagenoeg alle aanwezige kruiden.

Tabel 3.5. Overzicht van de ongewenste tot problematische niet inheemse plantensoorten op de golf.

\begin{tabular}{|l|l|cl|}
\hline Wetenschappelijke naam & Nederlandse naam & Abundantie & \\
\hline Abeel / populier & Populus spec. & 6,7 & ha \\
Zwarte den & Pinus nigra & 0,5 & ha \\
Boksdoorn & Lycium barbarum & 3200 & $\mathrm{~m}^{2}$ \\
Rimpelroos & Rosa rugosa & 1730 & $\mathrm{~m}^{2}$ \\
Olijfwilg (E. cf. ebbingei) & Eleagnus cf. ebbingei & 1570 & $\mathrm{~m}^{2}$ \\
Olijfwilg (E. angustifolia) & Eleagnus angustifolia & 1070 & $\mathrm{~m}^{2}$ \\
Haagliguster & Ligustrum ovalifolia & 966 & $\mathrm{~m}^{2}$ \\
Tamariks sp. & Tamariks sp. & 482 & $\mathrm{~m}^{2}$ \\
Struikaster & Baccharis halimifolia & 325 & $\mathrm{~m}^{2}$ \\
Amerikaanse vogelkers & Prunus serotina & 303 & $\mathrm{~m}^{2}$ \\
(lerse) Klimop & Hedera hibernica & 264 & $\mathrm{~m}^{2}$ \\
Watercrassula & Crassula helmsii & 93 & $\mathrm{~m}^{2}$ \\
Valse indigo & Amorpha fruticosa & 5 & Individuen \\
Sering & Syringa vulgaris & 3 & Individuen \\
Hartbladige els & Alnus cordata & 1 & Individu \\
Peterseliebraam & Rubus laciniatus & 1 & Individu \\
Steeneik & Quercus ilex & 1 & Individu \\
\hline
\end{tabular}

\subsection{Permanente kwadraten}

Tabel 3.6. geeft de soortensamenstelling weer in de 6 permanente vegetatieproefvlakken van $3 \times 3$ $\mathrm{m}^{2}$ die in 2017 op de golf werden opgenomen. In totaal werden 89 soorten aangetroffen waarvan 6 aandachtssoorten. De vegetatie is behoorlijk soortenrijk en kan ook tot habitatwaardige vegetatietypen worden gerekend. Voor proefvlakken gh_01 t.e.m. gh_05 betreft het duingraslanden (type 2130) en voor gh_07 duinvalleivegetaties (type 2190). Uit analyse van bodemstalen in de graslanden blijkt dat de totale concentratie aan fosfor zich bevindt tussen 200 en $300 \mathrm{mg} \mathrm{P} / \mathrm{kg}$. Dit zijn lage concentraties die binnen het bereik liggen van de referentiewaarden voor duingraslanden (Provoost et al. 2018). 
Tabel 3.6. Soortensamenstelling van de 6 permanente kwadraten, opgenomen in de golf.

\begin{tabular}{|c|c|}
\hline & gh_01 \\
\hline Aantal soorten & 27 \\
\hline Totale bedekking (\%) & 99 \\
\hline Bed. Kruidlaag (\%) & 85 \\
\hline Bed. Moslaag (\%) & 97 \\
\hline Bed. Strooisel (\%) & 3 \\
\hline Gemiddelde hoogte $(\mathrm{cm})$ & 10 \\
\hline Achillea millefolium & - \\
\hline Agrostis capillaris & . \\
\hline Agrostis stolonifera & - \\
\hline Anthoxanthum odoratum & - \\
\hline Anthyllis vulneraria & - \\
\hline Arrhenatherum elatius & . \\
\hline Avenula pubescens & 2 \\
\hline Bromus hordeaceus & $\mathrm{p} 1$ \\
\hline Calamagrostis epigejos & - \\
\hline Carex arenaria & $\mathrm{p} 1$ \\
\hline Carex flacca & - \\
\hline Carex viridula & - \\
\hline Centaurium littorale & - \\
\hline Cerastium arvense & -1 \\
\hline Cerastium fontanum & . \\
\hline Cirsium arvense & - \\
\hline Convolvulus arvensis & - \\
\hline Crepis capillaris & - \\
\hline Dactylis glomerata & . \\
\hline Diplotaxis tenuifolia & - \\
\hline Eleocharis palustris & - \\
\hline Elymus athericus & $1+$ \\
\hline Elymus repens & - \\
\hline $\begin{array}{l}\text { Equisetum arvense } \\
\text { Elat }\end{array}$ & - \\
\hline Erodium cicutarium ssp dunenense & p1 \\
\hline Eupatorium cannabinum & - \\
\hline $\begin{array}{l}\text { Festuca filiformis } \\
\text { Finding }\end{array}$ & - \\
\hline Festuca glauca & $\mathrm{p} 1$ \\
\hline Festuca rubra & 3 \\
\hline Galium verum & -1 \\
\hline Geranium molle & - \\
\hline Hieracium umbellatum & $r 1$ \\
\hline Holcus lanatus & - \\
\hline Hydrocotyle vulgaris & - \\
\hline Hypochaeris radicata & a2 \\
\hline Juncus articulatus & - \\
\hline Juncus inflexus & - \\
\hline Koeleria albescens & a1 \\
\hline Leontodon saxatilis & $\mathrm{p} 1$ \\
\hline $\begin{array}{l}\text { Lolium perenne } \\
\end{array}$ & $\mathrm{p} 1$ \\
\hline Lotus corniculatus & - \\
\hline Luzula campestris & - \\
\hline Lysimachia vulgaris & \\
\hline Medicago lupulina & - \\
\hline Mentha aquatica & - \\
\hline Ononis repens & $1+$ \\
\hline Phleum pratense & $\mathrm{p} 1$ \\
\hline Phragmites australis & - \\
\hline $\begin{array}{l}\text { Plantago lanceolata } \\
\text { Plats }\end{array}$ & a4 \\
\hline Plantago major & - \\
\hline Poa pratensis & p1 \\
\hline Potentilla reptans & - \\
\hline Pulicaria dysenterica & - \\
\hline Ranunculus bulbosus & $\mathrm{p} 1$ \\
\hline Ranunculus flammula & - \\
\hline Ranunculus repens & - \\
\hline Rubus caesius & - \\
\hline Salix repens & . \\
\hline Samolus valerandi & . \\
\hline Sedum acre & $\mathrm{p} 1$ \\
\hline Senecio jacobaea & - \\
\hline $\begin{array}{l}\text { Sonchus arvensis } \\
\text { Stat }\end{array}$ & . \\
\hline Taraxacum vulgare groep & $\mathrm{p} 1$ \\
\hline Thalictrum minus subsp. dunense & - \\
\hline Thymus pulegioides & - \\
\hline Tragopogon pratensis & - \\
\hline Trifolium arvense & $\mathrm{p} 1$ \\
\hline Trifolium campestre & - \\
\hline Trifolium dubium & - \\
\hline Trifolium fragiferum & - \\
\hline Trifolium repens & - \\
\hline Trifolium scabrum & $\mathrm{r} 1$ \\
\hline Trisetum flavescens & - \\
\hline Vicia cracca & - \\
\hline Vicia sativa subsp. nigra & - \\
\hline Mossen & - \\
\hline Aneura pinguis & - \\
\hline Brachythecium al bicans & .4 \\
\hline Brachythecium rutabulum & - \\
\hline Bryum argenteum & - \\
\hline Bryum spec. & - \\
\hline Ceratodon purpureus & - \\
\hline Cladonia rangiformis & .1 \\
\hline Eurhynchium praelongum & - \\
\hline Hypnum cupressiforme var. lacunosum & 9 \\
\hline Plagiomnium affine & . \\
\hline Pseudoscleropodi purum & - \\
\hline Rhynchostegium megapolitanum & - \\
\hline $\begin{array}{l}\text { Rhytidiadelphus squarrosus } \\
\text { R }\end{array}$ & . \\
\hline Tortula ruralis var. ruraliformis & . \\
\hline
\end{tabular}




\section{Ecologische waarde, knelpunten en potenties}

\subsection{Visie op natuurontwikkeling}

De golf van De Haan heeft op botanisch vlak heel wat te bieden. De ecologische waarden zijn in hoofdzaak te vinden in de gemaaide roughs, die tot de soortenrijkere duingraslanden van onze kust kunnen gerekend worden. In het kader van de Europese habitatrichtlijn maken deze graslanden deel uit van het prioritair te beschermen habitattype 2130, 'gefixeerde duinen met kruidachtige vegetatie'. In deze studie werd de ecologische waarde enkel bekeken aan de hand van de flora maar we kunnen er van uit gaan dat ook de fauna van de duingraslanden heel wat te bieden heeft, bijvoorbeeld op het vlak van plantenbezoekende insecten (figuur 4.1). In totaal werden de voorbije 15 jaar 51 aandachtssoorten vaatplanten op de golf gekarteerd. Dat is een groot aantal, vergelijkbaar met een aantal bijzondere gebieden zoals de oude duinen Cabour in Adinkerke of de Oostvoorduinen in Oostduinkerke. Voor ruwe klaver en bokkenorchis herbergt de golf van De Haan de grootste populaties aan de kust en daarmee meteen ook binnen Vlaanderen.

Hieruit blijkt dat de ecologische waarde van het golfterrein het lokale overstijgt en ook op regionaal en zelfs internationaal niveau een bijdrage levert aan het netwerk van natuurgebieden en populaties van bijzondere soorten. Gezien het gebied deel uitmaakt van de speciale beschermingszone afgebakend in het kader van de Europese habitatrichtlijn (SBZ-h BE2500001 Duingebieden inclusief IJzermonding en Zwin), draagt het ook een verantwoordelijkheid bij de realisatie van de wettelijk vastgelegde instandhoudingsdoelstellingen (IHD) voor deze natuurwaarden.
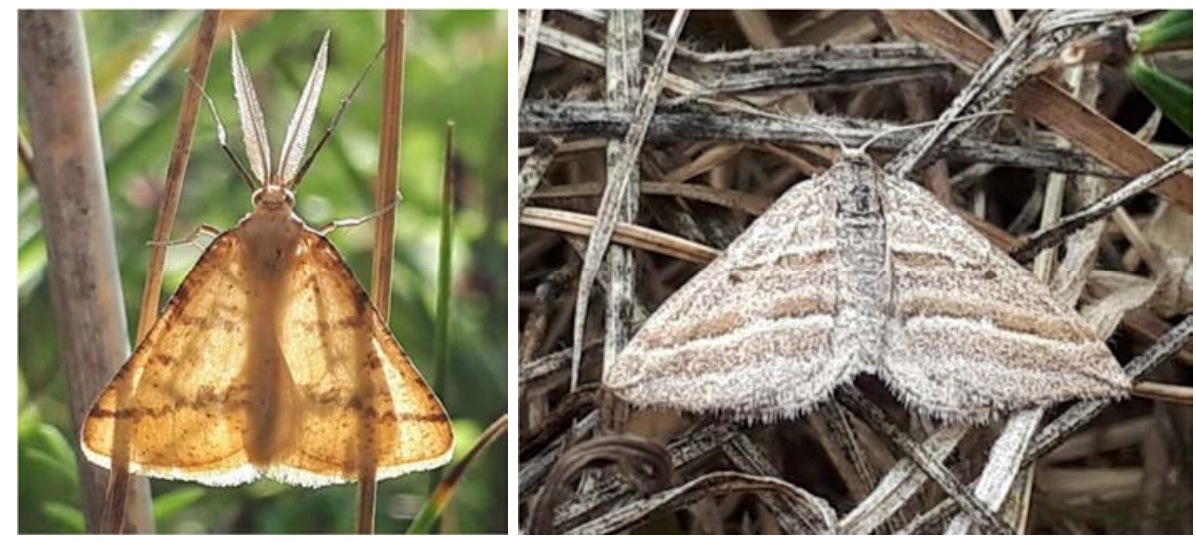

Figuur 4.1. Gele kustspanner en echt-walstrospanner, twee kustspecifieke nachtvlinderssoorten van duingraslanden aangetroffen op de golf.

De instandhoudingsdoelstellingen omvatten hogere ambities dan het louter behouden van de actuele oppervlaktes aan habitats en populaties van soorten. Zo is er (met uitzondering van duindoornstruweel) voor alle habitattypes een uitbreiding van de oppervlakte voorzien. Op golf van De Haan zijn er vooral potenties voor de uitbreiding van duingrasland (habitattype 2130) en in zeer beperkte mate voor duinvalleien (2190). Voor duinstruweel (2160) en duinbos (2180) kan uitbreiding van het type gerealiseerd worden door omvorming en geschikt beheer vanuit bestaande aanplanten van struweel en bos op het terrein. De habitatrichtlijn omvat namelijk niet enkel kwantitatieve oppervlaktedoelstellingen, ook de habitatkwaliteit dient te voldoen aan de criteria voor een lokaal gunstige staat van instandhouding (LSVI-criteria, T'Jollyn et al.2009).

Naast het gegeven van de kwantitatieve instandhoudingsdoelstellingen, waarvoor we op zoek gaan naar de locaties met de hoogste potenties om deze te realiseren, vormt ook de exotenproblematiek een belangrijk uitgangspunt voor de natuurontwikkelingsvisie binnen het golfterrein van De Haan. Zoals hoger aangehaald is het wenselijk om alle aanplanten en spontane uitbreiding van uitheemse 
struiken en bomen op termijn uit het gebied te verwijderen met uitzondering van populieren en abelen in bosverband, waar omvorming naar inheemse bosbestanden wenselijk is.

\subsection{Omvorming van uitheemse struwelen en bossen}

Zoals onder '3.3 Uitheemse planten' aangehaald, is het wenselijk de talrijke aanplanten van uitheemse struiken en bomen om te vormen naar inheemse vegetaties. Voor een gedeelte is omvorming naar kruidachtige vegetaties aangewezen (zie verder) maar voor het merendeel van de bestanden stellen we omvorming voor naar inheemse struwelen, houtkanten of bossen. De soortenkeuze is afhankelijk van de doelstelling: bos, houtkant of haag/struweel. Bij aanplanten grenzend aan kruidachtige vegetaties worden best enkel struiken gebruikt om beschaduwing van en bladval op de open habitats te minimaliseren.

Bij voorkeur wordt enkel gebruik gemaakt van autochtoon plantmateriaal. Soorten die daarvoor in aanmerking komen worden weergegeven in tabel 4.1. Voor meer informatie over autochtoon plantmateriaal en leveranciers verwijzen we naar:

https://www.natuurenbos.be/autochtonebomen

http://www.plantvanhier.be/

Tabel 4.1. Lijst van aanbevolen soorten voor aanplant op de golf van De Haan.

\begin{tabular}{|l|l|l|}
\hline Wetenschappelijke naam & Nederlandse naam & Groeivorm \\
\hline Acer campestre & Veldesdoorn / Spaanse aak & Struik / Boom \\
Alnus glutinosa & Zwarte els & Boom \\
Betula pendula & Ruwe berk & Boom \\
Betula pubescens & Zachte berk & Boom \\
Cornus sanguinea & Rode kornoelje & Struik met vegetatieve uitbreiding \\
Corylus avellana & Hazelaar & Struik \\
Crataegus monogyna & Eenstijlige meidoorn & Struik \\
Euonymus europaeus & Wilde kardinaalsmuts & Struik \\
Ligustrum vulgare & Wilde liguster & Struik \\
Populus tremula & Ratelpopulier & Struik / Boom met vegetatieve uitbreiding \\
Prunus avium & Boskers / Zoete kers & Boom \\
Prunus padus & Gewone vogelkers & Struik / Boom \\
Prunus spinosa & Sleedoorn & Struik met vegetatieve uitbreiding \\
Quercus robur & Zomereik & Boom \\
Rhamnus frangula & Sporkehout / Vuilboom & Struik \\
Rosa canina & Hondsroos & Struik \\
Rosa tomentosa & Viltroos & Struik \\
Sorbus aucuparia & Wilde lijsterbes & Struik / Boom \\
Tilia cordata & Winterlinde & Boom \\
Ulmus laevis & Fladderiep / steeliep & Boom \\
Ulmus minor & Gladde iep / veldiep & Boom / Struik met wortelopslag \\
Viburnum opulus & Gelderse roos & Struik \\
\hline
\end{tabular}


Voor de zones die een schermfunctie hebben, is een gefaseerde aanpak wenselijk waarbij de omvorming geleidelijk gebeurt zonder grote open zones te creëren. Het duurt immers een aantal jaren vooraleer aanplant van inheemse bomen en struiken vanuit bosplantsoen voldoende volume inneemt om de schermfunctie over te nemen. In zones voorzien voor omvorming naar lage vegetaties is volledige kapping het meest efficiënt, zowel voor wat betreft de eenmalige ingreep als voor de nazorg (mogelijke heropslag).

\subsection{Ontwikkeling van vochtige duinvalleien}

Mogelijkheden voor de ontwikkeling van kruidachtige vegetaties van vochtige duinvalleien hangen nauw samen met de hydrologie en topografie van het terrein. Figuur 4.2 geeft een beeld van de bodemvochtigheid in het terrein uitgedrukt in diepte van de gemiddelde grondwatertafel onder het maaiveld. De kaart is opgemaakt door interpolatie van de gemiddelde stijghoogtes in 16 peilbuizen in de periode 2011-2018. Het verschil tussen de hieruit resulterende stijghoogtekaart en het hoogtemodel DHM Vlaanderen II vormt de vochtkaart in figuur 4.2. Vochtige terreindelen, waar de gemiddelde watertafel zich minder dan een meter onder maaiveld bevindt, zijn schaars op de golf. Het betreft vooral de zones waar zich actueel reeds duinvalleivegetaties hebben ontwikkeld en uiteraard de open waters. Daarnaast bevinden zich vochtige zones op de fairways van holes 2 en 18. Deze zones zijn 's winters moeilijk te bespelen zijn door wateroverlast.

Door afgraven van de bodem kan de hoogte van het maaiveld boven de grondwatertafel worden verminderd waardoor geschikte condities ontstaan voor de ontwikkeling van duinvalleivegetaties. Mogelijkheden hiervoor zijn in de praktijk echter beperkt. Het uitgraven van depressies voor de creatie van duinvalleien kan eventueel gecombineerd worden met het lokaal ophogen van te natte fairways (holes 2 en 18). Dergelijke aanpak heeft met succes gewerkt op hole 4.

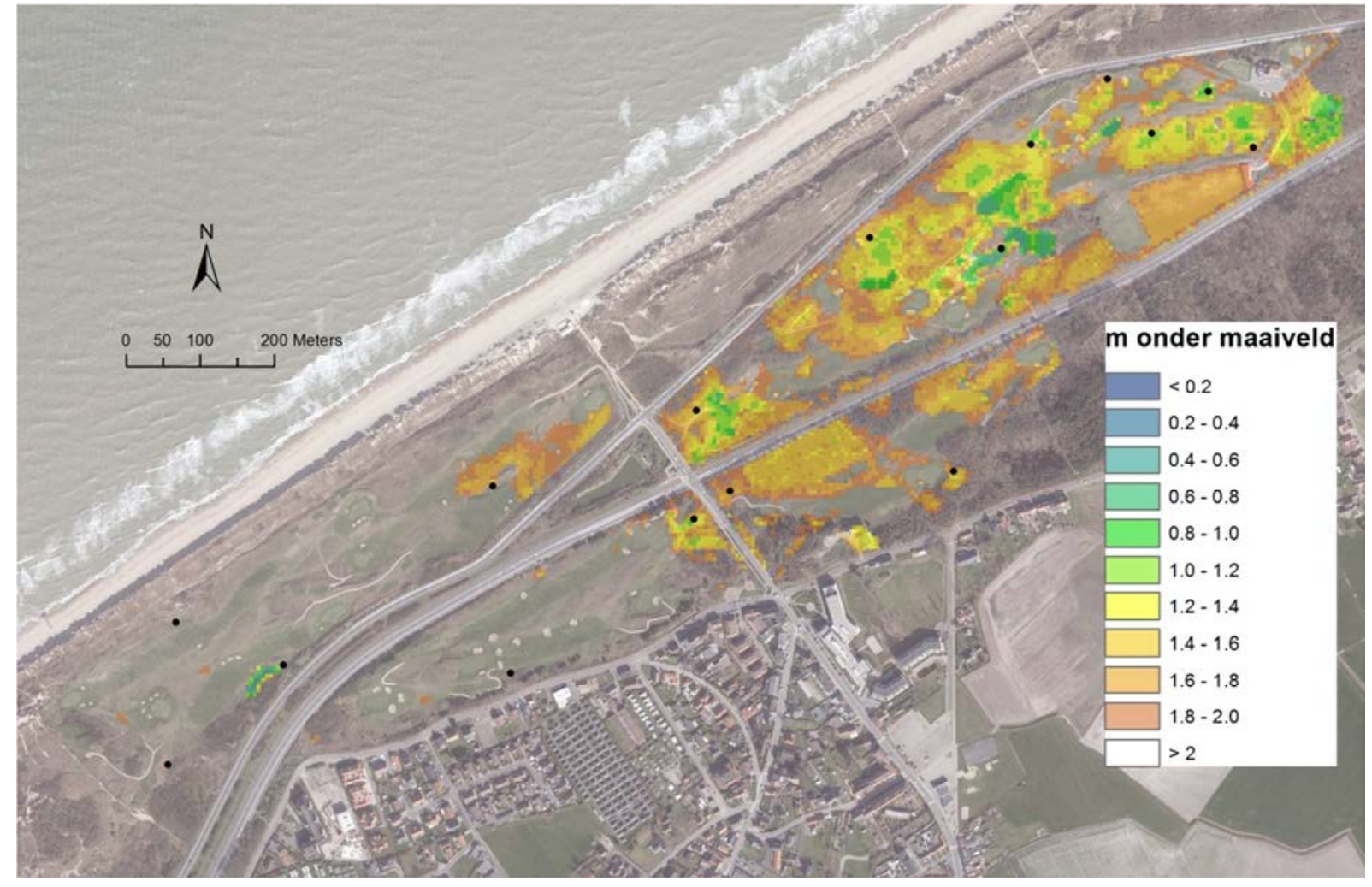

Figuur 4.2. Bodemvochtigheid uitgedrukt in diepte van de gemiddelde grondwatertafel onder maaiveld. De zwarte bollen zijn de peilbuizen. 
De met watercrassula overgroeide depressie ten oosten van hole 9 (figuur 4.3, 4.4.a) vergt een bijzondere aanpak. Zoals hoger aangehaald kan de soort zich heel snel uitbreiden waarbij nagenoeg alle aanwezige kruiden worden verdrongen. De soort kan zich vestigen vanuit kleine deeltjes van de plant of vanuit zaad (D'Hondt et al. 2016). Over de persistentie van de bodemzaadvoorraad bestaat echter onzekerheid. We stellen volgende aanpak voor:

1) Aanleg van en werfweg naar de locatie (figuur 4.3) die later eventueel ook voor het beheer kan worden gebruikt.

2) Verwijderen van de opgaande vegetatie in en rond de panne (o.m. grauwe wilgen). Het is belangrijk dat het plantenmateriaal vanuit het terrein rechtstreeks wordt afgevoerd naar een locatie waar het wordt gecomposteerd of verbrand. De watercrassula wordt daarbij zoveel mogelijk onaangeroerd.

3) Afdekken van de gehele depressie met ca. $40 \mathrm{~cm}$ zand.

4) $\mathrm{Na}$ enkele jaren kan het zand weer worden afgegraven en kan de depressie/poel worden hersteld. Er kan bijvoorbeeld na 3 jaar een test van enkele $\mathrm{m}^{2}$ worden uitgevoerd waarbij gekeken wordt of crassula weer opduikt.

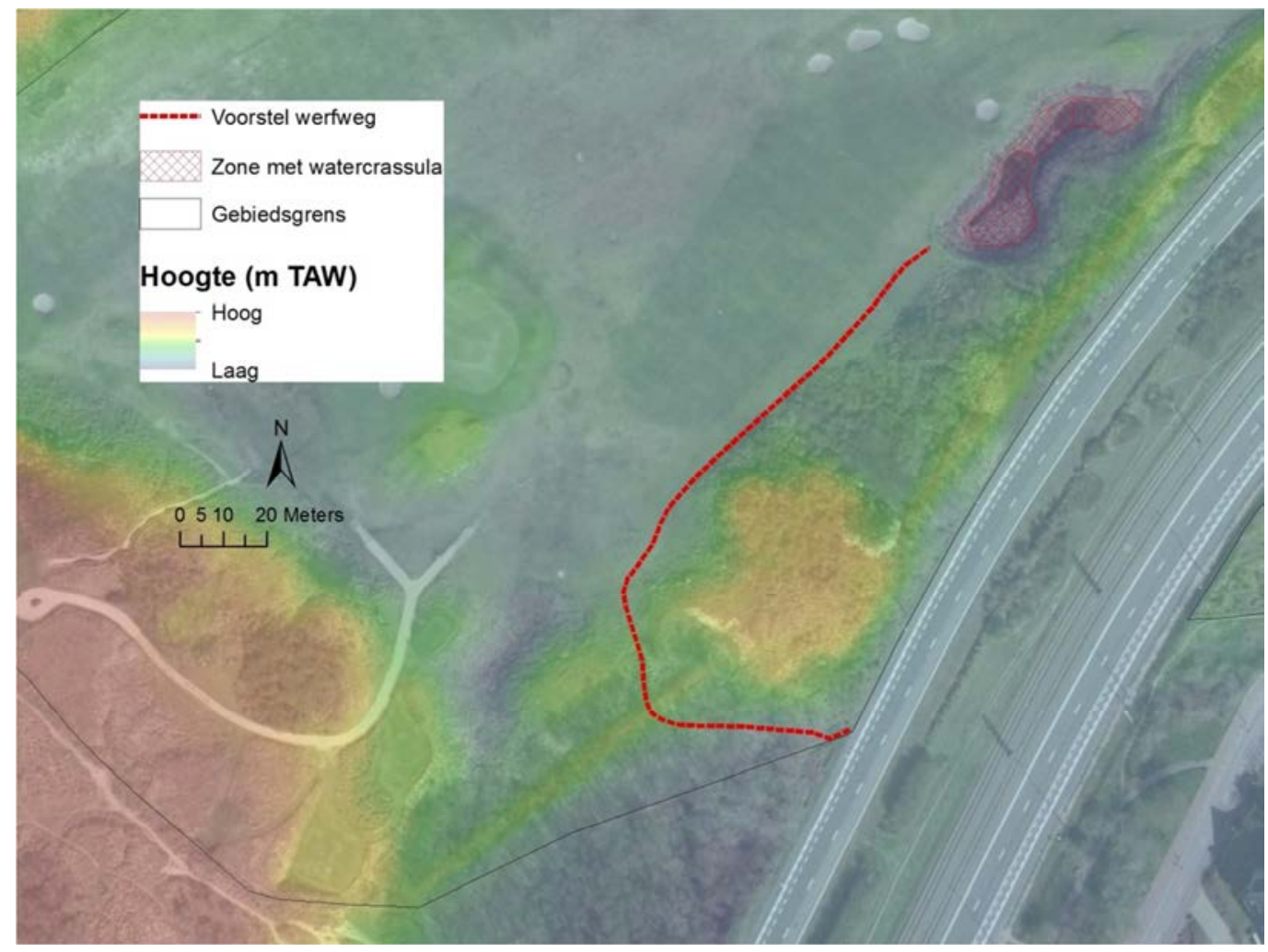

Figuur 4.3. Voorstel voor tracé van een werfweg voor de aanpak van waterceassula.

\subsection{Ontwikkeling van duingrasland}

Het areaal aan soortenrijk grasland is teruggedrongen door struweeluitbreiding (zie figuur 3.6), vergrassing en verruiging en aanplant van uitheemse struiken en bomen. Herstel is mogelijk door kappen van bomen en struweel in combinatie met een geschikt beheer. De hoogste potenties voor de ontwikkeling van duingraslanden liggen doorgaans in de onmiddellijke omgeving van bestaande graslandkernen. Zoals hoger aangehaald, beschikken veel (aandachts)soorten van duingrasland niet over goede verbreidingsmogelijkheden waardoor het aangewezen is vanuit de bestaande 
populaties te vertrekken. De erg kleine relictpopulaties van bevertjes, geel zonneroosje en kleine pimpernel verdienen prioritaire aandacht. Deze populaties zijn lokaal met uitsterven bedreigd, wat vermoedelijk met nachtsilene is gebeurd.

Vanuit deze potenties stellen we voor om struweel en bos te kappen en om te vormen naar duingrasland over een oppervlakte van 2,8 ha (tabel 4.2 , figuur 4.4 ). Het betreft 1,3 ha uitheems struweel; 0,3 ha bosaanplant en 0,6 ha duindoorn en ander inheems struweel. Het te kappen bos bestaat vooral uit Canadapopulier $\left(3400 \mathrm{~m}^{2}\right)$, gewone esdoorn $\left(2200 \mathrm{~m}^{2}\right)$, abelen $\left(1300 \mathrm{~m}^{2}\right)$ en dennen $\left(1000 \mathrm{~m}^{2}\right)$. Na het kappen van bomen is het uitfrezen van de stronken noodzakelijk om een maaibeheer mogelijk te maken. Een mogelijke techniek voor de abelenverwijdering is het afzagen van de stammen op ca. $80 \mathrm{~cm}$ gevolgd door het uittrekken van de wortels met een kraan met stevige grijper. Deze techniek werd toegepast in de Amsterdamse waterleidingduinen ( $\mathrm{NI}$ ) om Amerikaanse vogelkers te verwijderen en heeft als doel zoveel mogelijk van de ondergrondse plantendelen mee te verwijderen om heropslag te vermijden. Aanvullend wordt voorgesteld om $3550 \mathrm{~m}^{2}$ struweelopslag (vooral duindoorn) te bestrijden door maaien. Dit gebeurt bij voorkeur in de zomer omdat de planten dan het meest energie in de bovengrondse plantendelen hebben geïnvesteerd en zo sneller zullen verdwijnen.

Tabel 4.2. Oppervlakte van de éénmalige inrichtingsmaatregelen.

\begin{tabular}{|l|r|}
\hline Ingreep & Oppervlakte \\
\hline Watercrassula verwijderen & $424 \mathrm{~m}^{2}$ \\
Klimop verwijderen & $715 \mathrm{~m}^{2}$ \\
Duindoornopslag (zomer)maaien & $2469 \mathrm{~m}^{2}$ \\
Overige struweelopslag maaien & $363 \mathrm{~m}^{2}$ \\
Duindoorn kappen & $5477 \mathrm{~m}^{2}$ \\
Overig inheems struweel kappen & $826 \mathrm{~m}^{2}$ \\
Uitheems struweel kappen & $1,27 \mathrm{ha}$ \\
Kappen van uitheemse bosaanplant & $0,92 \mathrm{ha}$ \\
Aanplant van inheems struweel & $72 \mathrm{~m}^{2}$ \\
Omvorming van uitheems naar inheems struweel & $1,07 \mathrm{ha}$ \\
Omvorming van uitheems bos naar inheems struweel & $3265 \mathrm{~m}^{2}$ \\
Omvorming van uitheems bos naar inheemse houtkant & $970 \mathrm{~m}^{2}$ \\
\hline Totaal & $\mathbf{4 , 7 2} \mathrm{ha}$ \\
\hline Geen inrichtingsmaatregelen & $52,72 \mathrm{ha}$ \\
\hline
\end{tabular}

\subsection{Beheer van duingrasland}

Naast de éénmalige inrichtingsmaatregelen zijn bijkomende recurrente beheerinspanningen noodzakelijk om de ecologische waarden op de golf duurzaam veilig te stellen. Vooreerst stellen we voor om een oppervlakte van 4,8 ha bijkomend als rough te beheren. Het betreft ongeveer een verdubbeling van de huidige oppervlakte (figuur 4.5, tabel 4.3). Deze roughs zijn geselecteerd in terreindelen met geringe reliëfverschillen zodat ze machinaal gemaaid kunnen worden. Ongeveer 1,1 ha is afkomstig uit te kappen struwelen of bossen, de overige zones betreffen verruigde graslanden. Afhankelijk van de uitgangssituatie is een jaarlijkse tot ca. 3-jaarlijkse maaibeurt gewenst. De ruigste terreindelen krijgen als overgangsbeheer best twee maaibeurten per jaar. Dit is zeker aangewezen als er nog opslag is van houtige planten. 


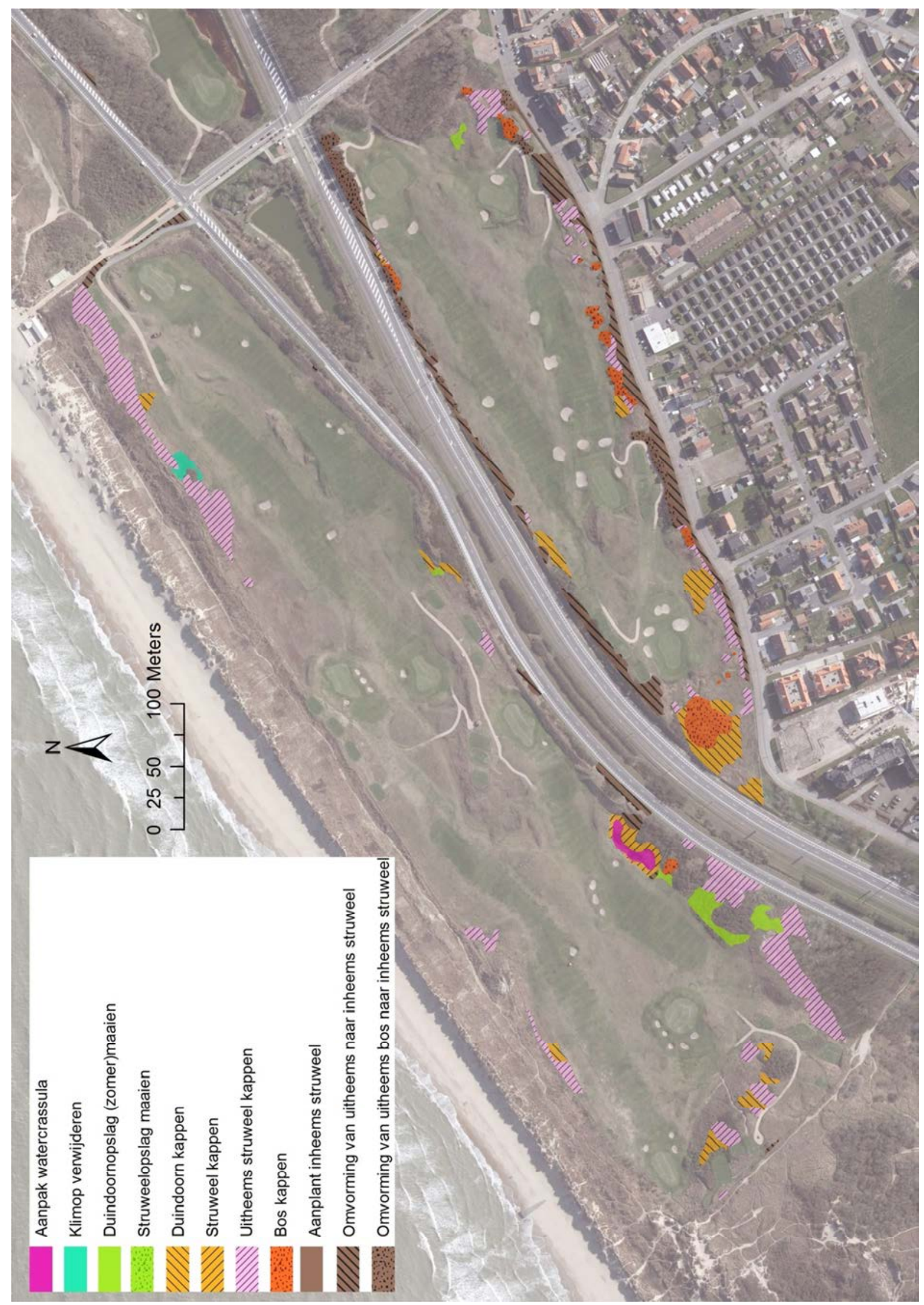

Figuur 4.4.a Inrichtingsvoorstellen voor de westelijke terreindelen. 


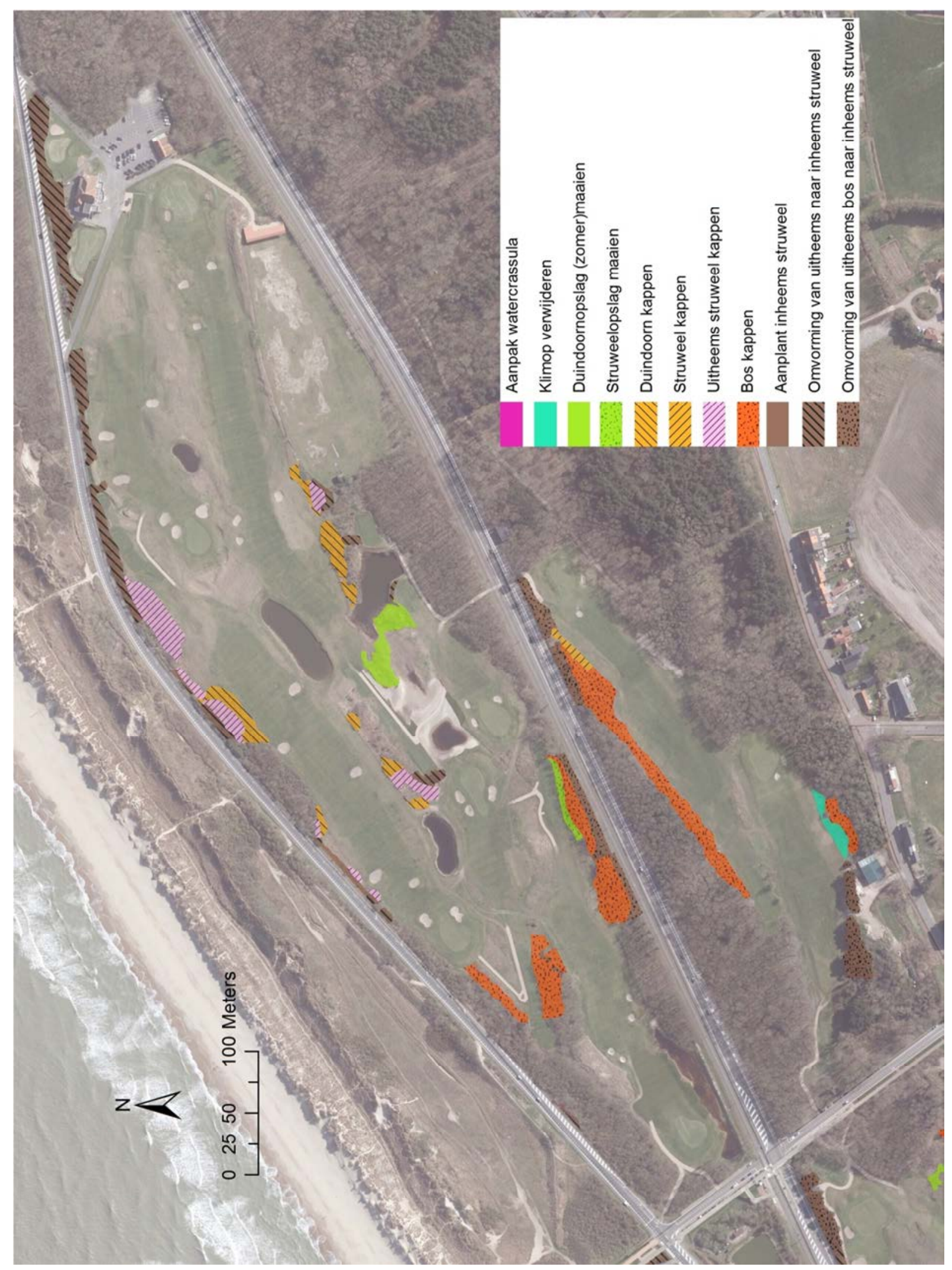

Figuur 4.4.b Inrichtingsvoorstellen voor de oostelijke terreindelen. 
Roughs met een schrale vegetatie worden best niet iedere maaibeurt volledig gemaaid om de aanwezige fauna te sparen. Het betreft vooral de invertebratenfauna maar ook broedvogels. Vooral de zone ten oosten van de green van hole 6 is een broedplaats voor patrijzen die in het broedseizoen best niet wordt gemaaid. We stellen voor om iedere maaibeurt ca. $20 \%$ van de rough ongemaaid te laten. Dit kan gebeuren in een voor de maaimachine handige configuratie (bijvoorbeeld strooksgewijs). In twee zones wordt een zoombeheer voorgesteld, namelijk de bosrand tussen de tee van hole 3 en de green van hole 2 en de bosrand ten noorden van hole 16 (figuur 4.5.b). Hier is een periodieke maaibeurt aangewezen om de ca. 5 jaar zodat zich een bloemenrijke ruigte kan ontwikkelen.

In reliëfrijke graslanden waar rijdende maaimachines niet kunnen ingezet worden, zal het maaibeheer met bosmaaier of eventueel met een performante motoculteur moeten gebeuren. Gezien het arbeidsintensieve karakter van dit beheer, stellen we voor deze terreindelen slechts eenmaal in de ca. 5 jaar te maaien. Zo kan een maaicyclus worden ingesteld waarbij ieder jaar één vijfde wordt gemaaid. Op die manier blijft ook een substantieel deel van het terrein ruig, wat gunstig is voor bepaalde invertebraten. Zo heeft bijvoorbeeld greppelsprinkhaan een duidelijke voorkeur voor sterk grazige vegetatie.

Tot slot stellen we voor om in twee zones, elk ca. 0,7 ha groot, een begrazingsbeheer in te stellen. Het betreft sterk geaccidenteerde terreinen waar machinaal maaien moeilijk is. Beheren van dergelijke oppervlaktes met bosmaaier is duur; begrazing is hier een logischer alternatief. Winterbegrazing met schapen is het meest aangewezen. Daarbij kan de vegetatie in het groeiseizoen tot bloei komen, wat gunstig is voor de insecten. De keuze voor schapen is enerzijds ingegeven vanuit praktisch oogpunt. Een begrazingseenheid van 0,7 ha is te klein voor de meeste grote herbivoren maar heeft vermoedelijk wel draagkracht om 2 schapen te laten overwinteren. Een tweede reden voor het gebruik van schapen is de band met de historiek van linksgolfterreinen.

Tabel 4.3. Oppervlakte van het actueel maaibeheer en de voorgestelde bijkomstige beheermaatregelen.

\begin{tabular}{|l|c|l|c|}
\hline Huidig beheer & Oppervlakte (ha) & Beheervoorstellen & Oppervlakte (ha) \\
\hline Green \& Tee & 1,86 & Rough machinaal gemaaid & 4,79 \\
Tee banking & 0,49 & Periodiek machinaal maaien & 0,44 \\
Pad & 1,05 & Periodiek maaien met bosmaaier & 3,83 \\
Fairway & 9,72 & Begrazing & 1,65 \\
Oefenterrein & 1,39 & & \\
Semi-rough & 9,51 & & \\
Rough & 4,07 & & $\mathbf{3 8 , 8 0}$ \\
\hline Totaal beheer & $\mathbf{2 8 , 0 9}$ & & $\mathbf{1 5 , 0 6}$ \\
\hline Geen beheer & $\mathbf{2 5 , 7 7}$ & & \\
\hline
\end{tabular}




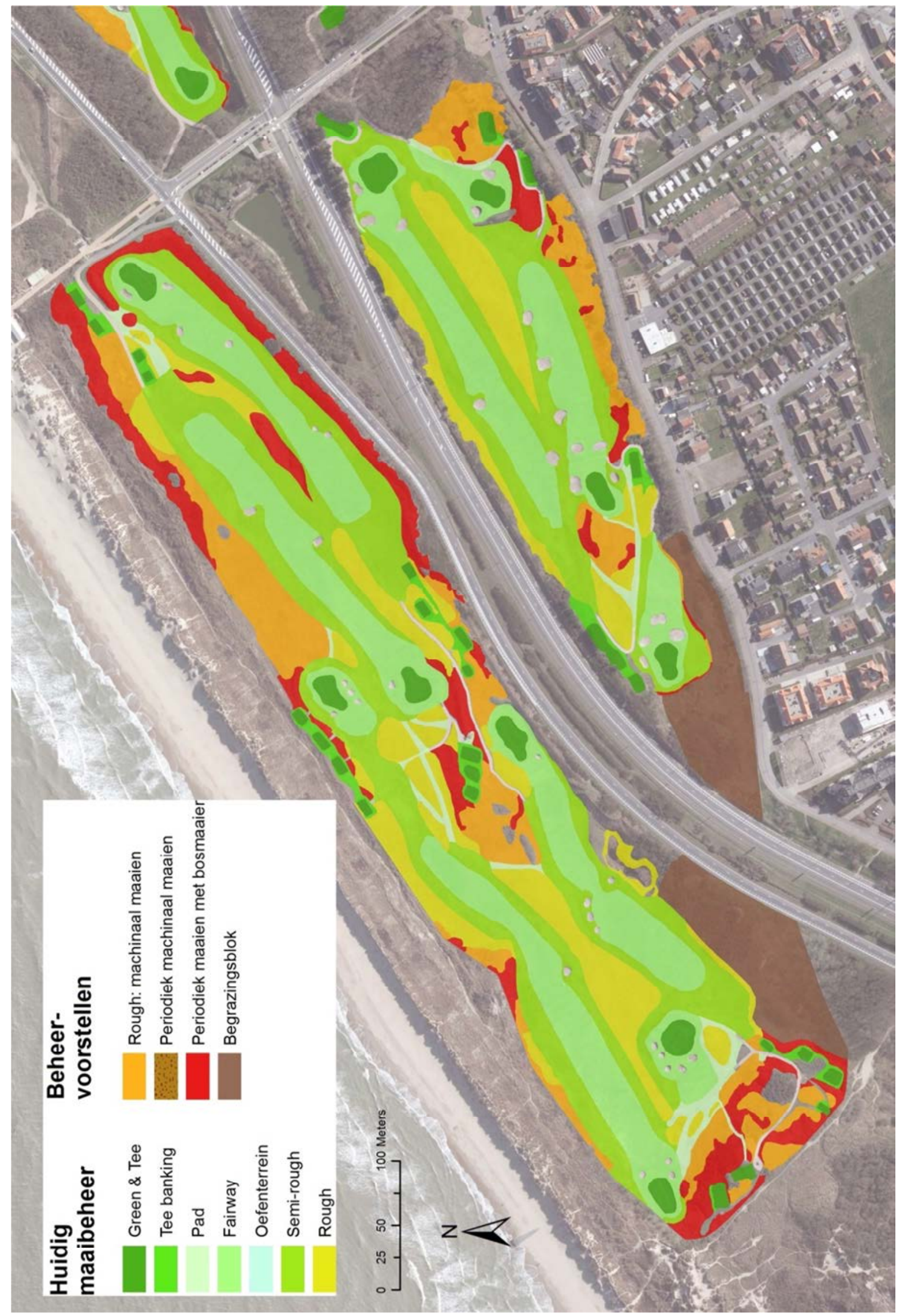

Figuur 4.5.a Actueel maaibeheer en beheervoorstellen voor de westelijke terreindelen. 


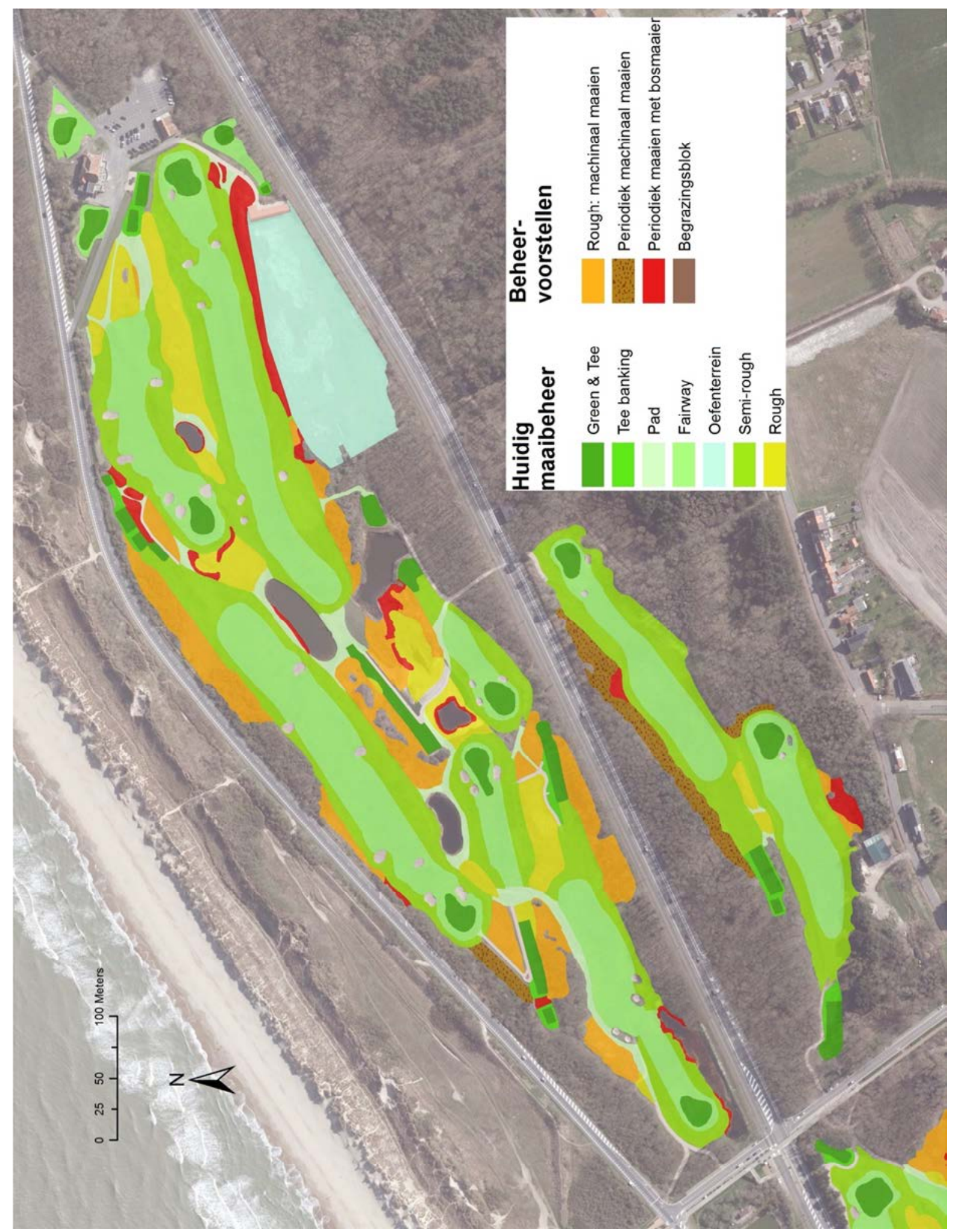

Figuur 4.5.b Actueel maaibeheer en beheervoorstellen voor de oostelijke terreindelen. 


\subsection{Biotisch herstel}

Een laatste optie voor het beheer van de waardevolle duinvegetaties op de golf van De Haan die we hier aanhalen is het biotisch (botanisch) herstel. Hiermee bedoelen we het versterken van populaties van kwetsbare plantensoorten of de herintroductie van recent verdwenen soorten vanuit naburige populaties. Dergelijke ingrepen kunnen we verantwoorden doordat de actuele populaties in omvang zijn afgenomen en versnipperd door urbanisatie en habitatdegradatie. Veelal is er daarbij nog onvoldoende genetische uitwisseling mogelijk tussen de deelpopulaties waardoor zij extra kwetsbaar worden voor veranderingen in het milieu (Mergeay 2017).

Zoals aangehaald onder 4.4 zijn vooral duingraslandsoorten hiervoor gevoelig door hun relatief beperkte verbreidingscapaciteiten en kortlevende zaden. Zeldzame graslandsoorten op de golf die in aanmerking komen voor versterking van de lokale populatie zijn gewone agrimonie, bevertjes, geel zonneroosje, beemdkroon en kleine pimpernel. De uitbreiding van deze soorten naar andere graslandzones kan heel eenvoudig door het manueel oogsten en uitzaaien van zaden. Voor herintroductie komen geelhartje, ogentroost sp. en nachtsilene in aanmerking. Bronpopulaties van deze soorten zijn onder meer te vinden in de Fonteintjes in Zeebrugge (geelhartje), de Warandeduinen in Middelkerke (nachtsilene, ogentroost), Ter Yde in Oostduinkerke (geelhartje, ogentroost), de golf van knokke (nachtsilene) en de Zwinduinen (ogentroost). Wat betreft duinvalleisoorten komt duingentiaan in aanmerking voor herintroductie. Deze soort duikt recent in verschillende duingebieden op door transport van zaden via maaimachines. De populatie uit het Westhoekreservaat in De Panne vormt de meest geschikte zaadbron. 


\section{Referenties}

Anoniem (G.C.) 2016. Orchideeën op ons terrein. Tee Time: 2.

Bunce R.H.G., Metzger M.J., Jongman R.H.G., Brandt J., De Blust G., Elena Rossello R., Groom G. B., Halada L., Hofer G., Howard D.C., Kováŕ P., Mücher C. A., Padoa-Schioppa E., Paelinckx D., Palo A., Perez-Soba M., Ramos I. L., Roche P., Skånes H., \& Wrbka T. 2008. A standardized procedure for surveillance and monitoring European habitats and provision of spatial data. Landscape Ecology 23: 11-25.

De Langhe J. E. 1944. Sur la dispersion géographique du Loroglossum hircinum (L.)L.C.Rich. en Belgique. Bull. Soc. Roy. Bot. Belg. 76: 20-30.

De Raeve F., Leten M. \& Rappé G. 1983. Flora en vegetatie van de duinen tussen Oostduinkerke en Nieuwpoort. Nationale Plantentuin van België, Meise. 176p. + fig.

D'hondt B., Denys L., Jambon W., De Wilde R., Adriaens T., Packet J. \& van Valkenburg J. 2016. Reproduction of Crassula helmsii by seed in western Europe. Aquatic Invasions 11 (22): 125-130.

Foley M.J.Y. 2005. Carex trinervis Degl. (Cyperaceae) - a western European coastal endemic. Candollea 60(1): 87-95.

Goetghebeur P. 1977. Catapodium marinum (L.) C.E. Hubbard, nieuw voor de Belgische flora. Dumortiera 64: 7-8.

Leten M., 1989. Distribution dynamics of orchid species in Belgium: past and present distribution of thirteen species. Mém. Soc. Roy. Bot. Belg. 11: 133-155.

Leten M., Provoost S. \& Lehouck V. 2012. Orchideeën aan de kust. De Grote Rede 32: 2-8.

Massart J. 1912. La cinquantième herborisation générale de la Société royale de botanique de Belgique sur le littoral belge. Bull. Soc. Roy. Bot. Belg. 51, fascicule I : 69-185 + fig. \& foto's.

Mergeay J. 2017. Translocaties in natuurbeheer. Controversieel en essentieel. Natuur.focus 16(3): 121-128.

Milotic T., Suyoto H.N., Provoost S. \& Hoffmann M. 2017. Herbivore-induced expansion of Helianthemum nummularium in grassland-scrub mosaic vegetation : circumstantial evidence for zoochory and indirect grazing impact. Plant ecology 218(7): 867-884.

Provoost S., Van Gompel W., Feys S., Vercruysse W., Packet J., Van Lierop F., Adams Y. \& Denys L. 2010. Permanente Inventarisatie van de Natuurreservaten aan de Kust, eindrapport periode 2007-2010. Rapport Instituut voor Natuur- en Bosonderzoek 2010.19, Brussel, 169p.

Provoost S., Raman M., Schelfhout S., Verheyen K., Vangansbeke P. De Schrijver A. 2018. Referentieonderzoek nutriënten voor bepalen van de kwaliteit van Europees beschermde duinhabitats: hoe problematisch zijn fosfaten aan de kust? Instituut voor Natuur- en Bosonderzoek, Labo voor Bos \& Natuur UGent \& Vakgroep Natuur- en Voedingswetenschappen HoGent.

Rappé \& Goetghebeur 1975. Crambe maritima L., nieuw voor de Belgische flora. Dumortiera 3: 1014.

T'Jollyn F., Bosch H., Demolder H., De Saeger S., Leyssen A., Thomaes A., Wouters J., Paelinckx D. \& Hoffmann M. 2009. Ontwikkeling van criteria voor de beoordeling van de lokale staat van instandhouding van de Natura 2000 habitattypen: Versie 2.0. Rapporten van het Instituut voor Natuur- en Bosonderzoek, 2009(46), Brussel, 326 p. 
Van Landuyt W., Vercruysse E. \& Zwaenepoel A. 2004. Trifolium filiforme in Flanders Fields: verspreiding en standplaatsen op militaire begraafplaatsen in de omgeving van Ieper (WestVlaanderen). Dumortiera 82: 10-15.

Van Landuyt W., Hoste I., Vanhecke L., Van Den Bremt P., Vercruysse W. \& de Beer D. (Ed.) 2006. Atlas van de flora van Vlaanderen en het Brussels Gewest. Flo.Wer/Instituut voor Natuur- en Bosonderzoek/Nationale Plantentuin van België, Brussel, 1007p.

Vannerom H. 1984. Juncus foliosus Desf., nieuw voor de Belgische flora in Genk (Limburg, België). Dumortiera 29-30: 59-60.

Verboven W. 1980. Duingraslandvegetaties van het golfterrein bij de Vosseslag (Klemskerke). Licentiaatsverhandeling RUG, 58 p.

Westra, T., Oosterlynck, P., Van Calster, H., Paelinckx, D., Denys, L., Leyssen, A., Packet, J., Onkelinx, T., Louette, G., Waterinckx, M. \& Quataert, P. 2014. Monitoring Natura 2000 - habitats: meetnet habitatkwaliteit. Rapporten van het Instituut voor Natuur- en Bosonderzoek 2014 (1414229), Brussel, 77p.

Zwaenepoel A., Leten M. \& Rappé G. 1994. Verspreiding, syntaxonomie en ecologie van Catapodium marinum (L.) C E. Hubbard en Sagina maritima G. Don aan de Belgische kust. Dumortiera 58-59: 28-41.

Verloove F. 2016. Les campings du littoral belge: un lieu de prédilection inattendu pour I'introduction de plantes exotiques. Natura Mosana 69: 1-2.

WES 2003. Milieubeheerplan voor de Koninklijke Golf Club van Oostende (KGCO). In opdracht van KGO. Brugge, 124 p. + bijlagen.

WVI 2004. Gebiedsvisie De Haan-Wenduine. In opdracht van AWZ-AWK \& Aminal- afdeling Natuur en afdeling Bos en Groen. Brugge, 136 p. + bijlagen. 